\title{
The "No-Problem" Problem: Feminist Challenges and Cultural Change
}

\author{
Deborah L. Rhode $\dagger$
}

\section{CONTENTS}

I. INTRODUCTION

II. The Denial of INJUSTICE 1737

A. The Historical Legacy 1737

1. Traditional Assumptions 1737

2. Legal Norms 1738

3. Feminist Responses 1739

B. Contemporary Frameworks 1744

1. The Cultural Context 1744 2. Conservative Ideology: Religious and
Sociobiological Premises

3. Gender Bias: Academic and Employment Settings 1750

III. The Denial of INEQuality 1755

A. The Embrace of Difference 1756

1. Employment 1757

2. Associations 1759

3. Athletics 1761

B. The Devaluation of Difference 1763

1. Occupational Inequality 1764

2. EEOC v. Sears as a Case Study 1768

IV. The DENIAL OF RESPONSIBILITY 1771

A. Relocating the Problem 1771

1. Strategies of Resistance 1771

2. Relative Deprivation 1773

$\uparrow$ Professor of Law and former Director of the Institute for Research on Women and Gender, Stanford University; B.A., 1974, J.D., 1977, Yale University. I am grateful for the comments of Barbara Babcock, Peter Chadwick, Cynthia Epstein, Robert Gordon, Thomas Grey, Angela Harris, David Luban, Toni Massaro, Frank Michelman, Robert Post, Carol Sanger, William Simon, and Michael Wald; the research of Joan Krause; the manuscript assistance of Diana Storm; and financial support from the Carl Robertson Fund. 
B. Relocating the Solution 1776

1. Victimizing the Victim 1776

2. Pay Equity 1777

C. Resisting Alternatives 1781

1. Individual Responses 1781

2. Institutional Responses 1782

3. Societal Responses 1783

V. REFoRmulating the PROBLEM: REASSESSING tHE RESPONSE 1784

A. Dilemmas of Difference 1784

1. The Validation of Difference 1784

2. Contextual Critiques 1786

B. Individualist Premises and Social Priorities 1791

1. Cultural Assumptions 1791

2. Collective Aspirations 1793

\section{INTRODUCTION}

Gloria Steinem, when invited to assess the impact of the women's movement, once responded that it felt like being asked to "describe the universe and give three examples." Questions about feminism's effects on the law draw similar responses. That was, however, the issue I was asked to address in commemoration of the twentieth anniversary of coeducation at Yale College. ${ }^{1}$ Although it would be impolite to ignore that topic, I cannot resist reformulating it slightly. What seems equally important is how feminism has not yet affected law and legal practice. To conclude on a more celebratory note, we should also consider how feminism, if given fuller expression, could affect law and legal practice.

As is often the case, the way a question is framed substantially changes the narrative that history records. Asking about the impact of feminism typically yields an uplifting account of Pilgrim's Progress, which stresses the dramatic changes in legal institutions and ideologies over the last two decades. Asking about the lack of impact evokes a competing myth of Sisyphus, which recites research on occupational inequality, income disparities, and sexual violence, and concludes that too many of us are still pushing the same rock up the same hill.

In some sense, the theme of this symposium testifies to the progress we have made. Such topics were not raised in polite company while I was in law school. Yale offered no course in sex discrimination, and when I first indicated

1. This Essay grows out of a symposium sponsored by the Women's Studies Program as part of Yale's commemorative series. Catharine MacKinnon, Martha Minow, and I were invited to speak in February 1990 concerning "How Feminism Has Affected Law and Legal Practice." 
interest in teaching such a course at Stanford, the Dean was horrified. Not only was it a field he diplomatically described as "mush," but it would "brand me as a woman." "Well," I responded with what I hoped was faint irony, "it probably won't come as a surprise to most of the world. And what, after all, is my alternative?" But to the Dean, the issue was academic credibility. And to establish that, I needed a "real" subject; he suggested negotiable instruments.

Credibility we have begun to acquire, but the social problems that prompted my concern are still with us. Despite substantial progress on gender issues over the last century, we remain stuck in similar places. Sexual violence remains common, and reproductive freedom is by no means secure. ${ }^{2}$ Women are dramatically underrepresented in the highest positions of social, economic, and political power, and dramatically overrepresented in the lowest positions. Over $85 \%$ of all elected officeholders are male; two-thirds of indigent adults are female. ${ }^{3}$ The work force remains highly gender segregated and gender stratified, with women of color at the bottom of the occupational hierarchy. Full-time female employees earn less than two-thirds of the annual wages of male workers, and a Black female college graduate on the average earns no more than a white male high school dropout. ${ }^{4}$

Whatever our progress in encouraging women to pursue traditional male roles, we have been less effective in encouraging men to assume traditional female ones. Women continue to shoulder the vast majority of responsibilities in the home, which limits their opportunities in the world outside it. ${ }^{5}$ Divorce law reform promised equal or equitable treatment between the spouses; in practice it continues to offer neither. Divorced women have a far greater

2. For example, it is estimated that $20-30 \%$ of all women will experience a violent assault outside of marriage. See surveys in S. ESTRICH, REAL RAPE 15-18 (1987). An almost equally large number will be beaten by men with whom they are intimately involved. See surveys discussed in FEMINIST PERSPECTIVES ON WIFE ABUSE (K. Yllo \& M. Bograd eds. 1988) (25-50\%); Waits, The Criminal Justice System's Response to Battering: Understanding the Problem, Forging the Solutions, 60 WASH. L. REV. 267, 273 (1985) (20\%). For curtailments on reproductive freedom, see, for example, Webster v. Reproductive Health Servs., 109 S. Ct. 3040 (1989); Harris v. McRae, 448 U.S. 297 (1980); Maher v. Roe, 432 U.S. 464 (1977); Jefferson, Reproductive Laws, Women of Color and Low-Income Women, in REPRODUCTIVE LAWS FOR THE 1990's (S. Cohen \& N. Taub eds. 1988).

3. See CENTER FOR AM. WOMAN \& POLITICS, WOMEN IN ELECTIVE OFFICE 1989: FACT SHeET (1989) (in 1989 women held $5 \%$ of federal elective offices, $14 \%$ of state executive elective offices, $17 \%$ of state legislative seats, and 9\% of county governing board positions); D. RHODE, JUSTICE AND GENDER 2 (1989); D. Pearce, The Feminization of Poverty: A Second Look (paper presented to American Soc. Ass'n Meetings, San Francisco, CA, Aug. 1989) (available from Institute for Women's Policy Research).

4. National COMM. ON PAY EQUTTY, BRiefing PAPER ON THE WAGE GAP (Briefing Paper No. 1, Apr. 1989) (hereinafter THE WAGE GAP]; P. ROTHENBERG, RACISM AND SEXISM: AN INTEGRATED STUDY 69-71 (1988); WOMEN'S WORK FORCE NETWORK OF WIDER OPPORTUNITIES FOR WOMEN, NATIONAL. COMM'N ON WORKING WOMEN, Overview of Women and Work, in WOMEN AT WORK, FACT SHEET (Winter 1990); NLRB Unveils Revised Set of Health Care Unit Rules, Daily Lab. Rep. (BNA) No. 170, at A-5 (Sept. 1,1988 ) (reviewing comparative salary data for college-educated women and male high school dropouts); Pearce, On the Edge: Marginal Women Workers and Employment Policy, in INGREDIENTS FOR WOMEN'S EMPLOYMENT POLICY 197 (1987) [collection as whole hereinafter INGREDIENTS]; see also infra text accompanying notes 164-65.

5. See infra note 202 and accompanying text. 
share of caretaking responsibilities and far fewer resources with which to discharge them. ${ }^{6}$

The law offers least to those who need it most. An increasing feminization of poverty has sharpened class divisions, and racial subordination remains pronounced. ${ }^{7}$ Many of the rights that the women's movement has struggled hardest to achieve in education, employment, and reproductive choice are available only to those who can afford to exercise them. Yet despite these patterns, the majority of women are unwilling to identify themselves as feminists. ${ }^{8}$ Most individuals, including those who support the basic objectives of the women's movement, decline to press them publicly, give them priority politically, or underwrite them financially. ${ }^{9}$

For feminists, a central problem remains the lack of social consensus that there is in fact a problem. To the public in general, and lawmakers in particular, sex-based disparities have often appeared natural, functional, and, in large measure, unalterable. A related problem is that many individuals who do perceive sex-based disparities as a problem conceive it too narrowly. Too much faith is placed in formal equality while too few strategies focus on the forces constraining it. Too often women are treated as a homogeneous group; too seldom does attention focus on the intersection of gender with other patterns of subordination such as class, race, ethnicity, and sexual orientation.

6. L. WeITzMan, THe DIVORCe Revolution 260-61, 355 (1985); Rhode \& Minow, Reforming the Questions, Questioning the Reforms: Feminist Perspectives on Divorce, in DIVORCE REFORM AT THE CROSSROADS 191 (S. Sugarman \& H. Kay eds. 1990).

7. On poverty, see M. KATZ, THE UNDESERVING POOR: FROM THE WAR ON POVERTY TO THE WAR ON WELFARE 242-44 (1989); D. Pearce, supra note 3. On racial deprivation, see, for example, A COMMON DESTINY: BLACKS AND AMERICAN SOCIETY 3-6, 16-21, 282-87, 291-99 (G. Jaynes \& R. Williams eds. 1989); P. ROTHENBERG, supra note 4; SLIPPING THROUGH THE CRACKS: THE STATUS OF BLACK WOMEN 293-94 (M. Simms \& J. Malveaux eds. 1986); Crenshaw, Race, Reform, and Retrenchment: Transformation and Legitimation in Antidiscrimination Law, 101 HARV. L. REV. 1331 (1988); Figart, Hartmann, Hoytt \& Outtz, The Wage Gap and Women of Color, 1989 WOMEN'S POL'Y RES. CONF. PROC. 25 (available from Institute for Women's Policy Research); McAdoo, A Portrait of African American Families in the United States, in THE AMERICAN WOMAN 1990-1991: A STATUS REPORT 71 (S. Rix ed. 1990) [collection as whole hereinafter THE AMERICAN WOMAN].

8. For the "I'm Not a Feminist But" phenomenon, see, for example, Wallis, Onward Women!, TTME, Dec. 4, 1989, at 80,85 (33\% of women interviewed considered themselves to be feminist; 58\% did not); Wickenden, What "NOW?," NEW REPUBLIC, May 5, 1986, at 19; Fleming, The American Wife, N.Y. Times, Oct. 26, 1986, \& 6 (Magazine), at 29.

9. See J. CHAFETZ, GENDER EQUTY: AN INTEGRATED THEORY OF STABILITY AND CHANGE 169-70 (1990) (women's movement even at maximum size has included only about 3\% of population; no significant "gender gap" in political preferences is apparent on gender equity issues); C. EPSTEIN, DECEPTIVE DISTINCTIONS: SEX, GENDER, AND THE SOCIAL ORDER 185 (1988) (one-third of women in Congress do not belong to Congressional Caucus for Women's Issues); A. MORRISON, R. WHTTE \& E. VAN VELSOR, BREAKING THE Glass CEILING: CAN WOMEN REACH THE TOP OF AMERICA's CORPORATIONS? 38-39 (1987) (discussing taboo on raising women's issues); WOMEN AND FOUNDATIONS/CORPORATE PHLANTHROPHY, FAR FROM DONE: THE STATUS OF WOMEN AND GIRLS IN AMERICA, at i (1988) (programs for women and girls account for $3.4 \%$ of foundation funding); Krier, Power: They Want it Now, L.A. Times, July 2, 1990, at E1, col. 6 (reporting that National Organization for Women has 260,000 members); Hume, Women Politicians Are Backing Away from Feminist Labels to Expand Base of Support, Wall St. J., Apr. 3, 1985, at 62 , col. 1 (discussing female politicians' unwillingness to identify themselves as feminists); infra note 212. 
This narrow conception of the problem reinforces attitudes that deny its existence. The achievement of individual rights fortifies the illusion that collective problems have been resolved. Whatever sex-based differences remain are frequently attributed to women's different "voice" and different choices. ${ }^{10}$ For most Americans, gender inequality is not a serious problem, or it is not their problem.

The following discussion reformulates this perception as the problem. By situating rationalizations for sex-based inequality within a broader historical, socioeconomic, and psychological context, these comments explore the relationship between legal ideology and feminist strategies.

Denials of a "woman problem" assume several forms that parallel other accounts of group-based subordination such as class and race. ${ }^{11}$ The most traditional approach has been to acknowledge gender disparities, but to deny their injustice. Under this view, sexual subordination reflects biological, religious, and cultural imperatives. A related strategy has been to deny that significant gender inequalities exist. This framework either celebrates or devalues gender differences; it affirms sex-linked roles as separate but equal, or, alternatively, denies the need for any accommodation of sex-linked attributes or experiences. A third approach is to concede the existence of sex-based injustices, but to deny responsibility for causing or remedying them. Adherents of this view embrace gender equality in principle while evading it in practice; they proclaim support for feminist objectives but dismiss feminist initiatives as unworkable, unaffordable, or someone else's obligation. Such strategies frequently victimize the victim. It is widely assumed, often by women themselves, that they deserve the subordination they experience, or that they must find individual solutions for shared dilemmas. As a result, the political remains only personal, and self-transformation masquerades as a substitute for social transformation.

The following discussion explores legal norms that reflect and reinforce these ideologies of denial as well as the feminist challenge that they present. By focusing on how gender inequality is discounted, dismissed, or deflected, we may gain a better sense of how it can be addressed.

As a threshold matter, it may be helpful to clarify terms. Although definitions of feminism vary, most incorporate two basic dimensions. At the substantive level, feminism implies a commitment to equality between the

10. The phrase is from C. GILLIGAN, IN A DIFFERENT VOICE: PSYCHOLOGICAL THEORY AND WOMEN'S DEVELOPMENT 1-2 (1982). For critical responses to this use of Gilligan's work, see infra text accompanying notes $269,272 \& 278$.

11. On issues of race, see, for example, Delgado, Storytelling for Oppositionists and Others: A Plea for Narrative, 87 MICH. L. REv. 2411, 2412-35 (1989) (discussing "stock stories" that enable members of racial majorities to see their position as natural or deserved). On issues of class, see M. KATZ, supra note 7, at 5-15, 67-69 (discussing how hardships of poverty are understated or attributed to individual laziness and vice); F. PARKIN, CLASS INEQUALTY AND POLITICAL ORDER: SOCIAL STRATIFICATION IN CAPITALIST AND COMMUNIST SOCIETIES 62-77 (1971) (analyzing how individuals' choices of reference groups and assumptions about meritocracy legitimate class structures). 
sexes. At the methodological level, it implies a commitment to gender as a focus of concern and to analytic approaches that reflect women's concrete experience. Underlying these commitments are certain core values of broader scope. Any ethical framework adequate to challenge gender subordination must similarly condemn the other patterns of injustice with which it intersects. Any political strategy responsive to the concerns of all women must, by definition, speak to inequalities not only of gender but also of class, race, ethnicity, age, and sexual orientation. A recurrent limitation of the women's movement has been its own denial of these wider dimensions of the "woman problem." The challenge for contemporary feminists is to build support for the broader social initiatives that the problem in fact requires. To realize its full potential, feminism must seek not only equal status for all women, but equal recognition for the values traditionally associated with them.

The discussion that follows includes particular attention to women's experiences at Yale and in the legal profession, both because this Essay marks a commemorative occasion for Yale University and because these experiences reflect broader cultural trends. Most versions of the "no-problem problem" have had their season in academic and professional circles. And for me, these contexts hold particular resonance since I came to Yale as an undergraduate in 1970, the second year of coeducation, remained through law school, and have returned intermittently as a legal scholar and trustee. By exploring ideologies of denial in academic and professional settings, the following analysis underscores some political implications of personal experience.

The paper's organizing theme is autobiographical in another sense. The "noproblem" ideology expresses variations on the most common response I have encountered over the last decade in teaching and writing about women's issues as well as in administering an institute that sponsors such work. Much of the time, the topic is greeted with polite skepticism, mild discomfort, or rhetorical questions. Of all the "important" social problems, why should attention focus on women, who, after all, have made such progress over the last quartercentury? To the extent that inequalities remain, does the solution really lie with more or different legal strategies? Aren't the remaining barriers primarily due to social forces beyond the scope of formal policy?

In responding to these questions, this Essay draws on a larger debate about the relationship between legal norms and gender hierarchies. The law provides a crucial structure in which ideologies of denial are reflected and renegotiated. By looking at how legal decisionmakers look at gender, we may gain a clearer sense of how social inequalities are discounted, legitimated, and ultimately resisted. 


\section{The Denial of INJUSTICE}

\section{A. The Historical Legacy}

\section{Traditional Assumptions}

Most people share what social psychologists have labeled a "belief in a just world." ${ }^{2}$ Individuals generally want to believe that life follows orderly, predictable, and equitable patterns in which everyone gets what they deserve and deserves what they get. To sustain this view, people will often adjust their evaluations of merit to justify existing social arrangements. ${ }^{13}$

Historically, the most common justification for sex-based disparities has been sex-based difference. Until the mid-nineteenth century, virtually all major political, philosophical, and theological frameworks relegated women to a separate and distinctly subordinate sphere. ${ }^{14}$ The prevailing assumption was that gender inequalities were biologically grounded, spiritually ordained, and culturally essential.

Scientific "wisdom" reinforced sex-based hierarchies. According to leading nineteenth-century experts such as Gustave le Bon, women's inferiority to men was "so obvious [that] . . . only its degree [was] worth discussion."15 The female's brain was too light, her forehead too small, her powers of reasoning too inadequate for demanding educational or occupational pursuits. ${ }^{16}$ Prominent medical authorities warned women about the deadly brain/womb conflict; those who diverted scarce biological resources from reproductive to cognitive functions risked chronic disabilities and permanent sterility. To tempt women from the proper duties of their sex risked deforming, defeminizing, and possibly depleting America's superior breeding stock. ${ }^{17}$

12. M. LERNER, THE BELIEF IN A JUST WORLD: A FUNDAMENTAL DELUSION, at vii-viii (1980).

13. Id. at 50-53. See generally F. HEIDER, THE PSYCHOLOGY OF INTERPERSONAL RELATIONS (1959); Apsler \& Friedman, Chance Outcomes and the Just World: A Comparison of Observers and Recipients, 31 J. PERSONALITY \& SOC. PSYCHOLOGY 887 (1975); Brewer, An Information Processing Approach to Attribution of Responsibility, 13 J. EXPERMENTAL SOC. PSYCHOLOGY 58 (1977); Comer \& Laird, Choosing to Suffer as a Consequence of Expecting to Suffer: Why Do People Do lt?, 32 J. PERSONALITY \& SOC. PSYCHOLOGY 92 (1975); Deaux, Sex: A Perspective on the Attributive Process, in 1 NEW DRECTIONS IN ATTRIBUTION RESEARCH 335, 339 (1976); Kelley, The Process of Casual Attribution, 28 AM. PSYCHOLOGIST 107 (1973); infra text accompanying notes 220-23.

14. See generally S. OKIN, WOMEN IN WESTERN POLITICAL THOUghT (1979); C. PATEMAN, THE DISORDER OF WOMEN: DEMOCRACY, FEMINISM AND POLITICAL THEORY (1989).

15. As quoted in J. GoULd, THE MISMEASURE OF MAN 104-05 (1981); see also W. KAMINER, A FEARFUL FREEDOM: WOMEN'S FLIGHT FROM EQUALITY, at Xiii-10, 41 (1990); C. RUSSETT, SEXUAL SCIENCE: THE VICTORIAN CONSTRUCTION OF WOMANHOOD (1989).

16. J. GOULD, supra note 15, at 103-07; 2 T. WOODY, A HISTORY OF WOMEN's EDUCATION IN THE UNITED STATES 346 (1929); Hyde, Meta-Analysis and the Psychology of Gender Differences, 16 SIGNS 55, 56-57 (1990); Maudsley, Sex in Mind and in Education, in MEN's IDEAS/WOMEN's REALITIES 77-86 (L. Newman ed. 1985).

17. E. ClarK, SEX IN EDUCATION: OR, A FAIR CHANCE FOR GRLS 104, 137 (1873) (discussing the "sterilizing" and "derang[ing]" effects of "excessive brain activity"); B. HARRIS, BEYOND HER SPHERE: WOMEN IN THE PROFESSIONS AND AMERICAN HISTORY 40-41, 58 (1978); C. SMITH-ROSENBERG, DISORDER- 
Gender inequality was assumed to be a cultural as well as biological imperative. For women to enter commercial and political life would mean "homes . . . ruined, children neglected" and civilized society imperiled. ${ }^{18}$ Since most educators believed that female instruction should be tailored to female roles, sex-based exclusions appeared appropriate for universities like Yale. John Trumbull captured traditional prejudices in late eighteenth-century verse:

Why should girls be learn'd and wise?

Books only serve to spoil their eyes.

The studious eye but faintly twinkles

And reading paves the way to wrinkles. ${ }^{19}$

\section{Legal Norms}

American law reflected and reinforced these societal assumptions. It offered no recourse against the norms that barred women from political participation and restricted their opportunities for paid labor. ${ }^{20}$ Under traditional commonlaw doctrines, wives had no right to hold, acquire, or convey property, retain their own wages, enter into contracts, or initiate legal claims. ${ }^{21}$

Underpinning these restrictions was an ideology of gender difference that institutionalized gender subordination. Judicial decisions upholding women's exclusion from the bar are a case in point. Female applicants' "peculiar qualities" were exaggerated and essentialized. ${ }^{22}$ State and federal supreme court justices discerned a law of "nature and the Creator" which decreed "the domestic sphere as that which properly belongs to the domain and functions of womanhood." 23 Although the precise method of divine communication was never elaborated, its message was often delivered. Woman's nature was to nurture; her "gentle graces ... [and] tender susceptibility" ill suited her to the rigors of professional life. ${ }^{24}$ Whether law was unfit for women, or women

LY CONDUCT: VISIONS OF GENDER IN VICTORIAN AMERICA 258-60 (1985); see also B. EHRENREICH \& D. ENGLISH, FOR HER OWN GOOD: 150 YEARS OF THE EXPERTS' ADVICE TO WOMEN 109-15 (1978). For discussion of the class and racial biases underlying these concerns, see sources cited infra note 43 .

18. See K. Blair, THE Clubwoman as Feminist: TRUe Womanhood Defined, 1868-1914, at 34, 70 (1980); see also A. AMES, SEX IN INDUSTRY: A PLEA FOR THE WORKING GIRL 30-31 (1986) (1875); A. SINCLAIR, THE BETTER HALF: THE EMANCIPATION OF THE AMERICAN WOMAN 323 (1966).

19. As quoted in Kerber, "Why Should Girls Be Learn'd and Wise?": Two Centuries of Higher Education for Women as Seen Through the Unfinished Work of Alice Mary Baldwin, in WOMEN AND HIGHER EDUCATION IN AMERICAN HISTORY 18, 21 (J. Faragher \& F. Howe eds. 1988).

20. See generally S. ANTHONY \& T. HARPER, HISTORY OF WOMAN SUFFRAGE (1902); E. FLEXNER, CENTURY OF STRUGGLE: THE WOMAN's RIGHTS MOVEMENT IN THE UNITED STATES (rev. ed. 1975); A. KRADITOR, THE IDEAS OF THE WOMEN's SUFFRAGE MOVEMENT 1890-1920 (1965); D. RHODE, supra note 3 , at $10-19,24-37,46-50$.

21. 1 W. Blackstone, Commentaries *430. See generally Women and tHe LaW: The Social HISTORICAL PERSPECTIVE (D. Weisberg ed. 1982) [hereinafter WOMEN AND THE LAW]; Basch, The Emerging Legal'History of Women in the United States: Property, Divorce, and the Constitution, 12 SIGNS 97 (1986).

22. See In re Goodell, 39 Wis. 232, 245 (1875).

23. Bradwell v. Illinois, 83 U.S. 130, 141 (1872) (Bradley, J., concurring).

24. In re Goodell, 39 Wis. at 245. 
unfit for law, the consequences were the same. Professional pursuits were a departure from the natural order and "when voluntary, treason against it." 25

\section{Feminist Responses}

In challenging such assumptions, advocates of women's rights followed two primary approaches. One was to deny the extent or essential nature of sex-based difference. Marshaling scientific, anthropological, and historical data, feminists revealed ostensibly biological distinctions as empirically unfounded or culturally constructed. That process highlighted obvious inconsistencies in gender ideology. Why should woman's "gentle graces" and maternal mission bar her from prestigious professions like law, but not grueling and indelicate occupations such as field and factory labor, where female immigrant and Black workers were clustered? $?^{26}$

An alternative strategy involved embracing rather than contesting difference. Under this approach, woman's distinctive moral attributes became grounds for including, not excluding, her from public life. For example, advocates for equal suffrage and equal access to legal institutions appealed not only to natural rights but also to natural roles. To the extent women were the same as men, they should enjoy the same opportunities. To the extent women were different, their special attributes warranted representation in public arenas. Under some circumstances, a woman lawyer's "silver voice" might "accomplish more than the severity and sternness of a man could achieve."27 Female jurors' "elevating and refining influence" might similarly enhance the quality of justice available to all citizens. ${ }^{28}$ Given women's moral sensibilities and nurturing values, their involvement could "purify" politics. ${ }^{29}$

Following this strategy to its logical conclusion, some feminists also invoked sex-based differences as a rationale for sex-specific protections. To these activists, true equality was obtainable only through measures that took into account the actual biological, social, and occupational differences between men and women..$^{30}$ As these feminists noted, female workers during the first

25. Id. at 244; see also In re Kilgore, 17 Phil. 14 (Pa. C. CP14 1884).

26. See generally P. GIDDINGS, WHEN AND WHERE I ENTER: THE IMPACT OF BLACK WOMEN ON RACE AND SEX IN AMERICA (1984); J. JONES, LABOR OF LOVE, LABOR OF SORROW: BLACK WOMEN, WORK AND THE FAMIIIY FROM SLAVERY TO THE PRESENT (1985); A. MIRANDE \& E. ENRIQUEZ, LA CHICANA: THE MEXICAN AMERICAN WoMan (1979); C. STANSELl, CITY OF WOMEN: SEX AND Class IN NEW YoRK, 1789-1860 (1986).

27. Bradwell v. Illinois, 83 U.S. 130, 137 (1872) (Carpenter, arguing for plaintiff in error).

28. WOMEN IN AMERICAN LAW 330 (M. Wortman ed. 1984); see also Garfinkle, Lefcourt \& Schulder, Women's Servitude Under Law, in LAW AGAINST THE PEOPLE: EsSAYS TO DEMYSTIFY LAW, ORDER AND THE COURTS 105-22 (R. Lefcourt ed. 1971).

29. S. ANTHONY \& T. HARPER, supra note 20 , at 39, 308-09.

30. W. Chafe, The AMERICAN WOMAN: Her ChangIng Social, ECONOMIC, AND POlITICAL Roles, 1920-1970, at 127 (1972); Kelly, Should Women Be Treated Identically with Men by the Law?, in SPECIAL LEGISLATION FOR WOMEN 86, 87 (J. Johnsen ed. 1926). See generally M. ANDERSON, WOMEN AT WORK (1951). 
part of the century earned lower wages and faced more exploitive working conditions than their male counterparts. Employment discrimination encouraged job turnover, which impeded unionization and minimized opportunities for seniority-based benefits and promotions. ${ }^{31}$ Not only were women at a competitive disadvantage in the paid labor force, they bore special burdens in the unpaid one. Household obligations, coupled with ten- to fourteen-hour work shifts, imposed crushing responsibilities. ${ }^{32}$ This double day discouraged married women from working and imposed enormous hardship upon those, especially women of color, who had no alternative to full-time labor. ${ }^{33}$ Such considerations led feminists to support sex-based maximum-hour and minimumwage legislation for female employees that legal decisionmakers were unwilling to extend to males. ${ }^{34}$

During the late nineteenth and early twentieth centuries, feminism gained increasing influence. Various factors, including the rise in women's education, employment, and political activism, apparently left both "nature and the Creator" with revised positions on gender roles. Struggles for the ballot, for married women's property rights, for protective labor legislation, for access to the professions, and for related entitlements helped transform the legal landscape. ${ }^{35}$

Yet with victory also came defeats. The ambivalence about difference carried a cost. Claims about women's superior qualities risked sentimentalizing and overstating their influence. Recognition of sex-based disadvantages in some measure perpetuated them. To be sure, sex-based protective legislation did bring crucial improvements for the majority of women crowded into predominantly female occupations. ${ }^{36}$ But as some feminists noted, the price was increased female unemployment and competitive disadvantage in occupations where male

31. A. KESSLER-HARRIS, WOMEN HAVE ALWAYS WORKED (1981); R. SMUTS, WOMEN AND WORK IN AMERICA 85 (1959); Baker, Protective Labor Legislation, with Special Reference to Women in the State of New York, 116 STUD. HIST., ECON. \& PUB. L. 207-10 (1925). See generally DOCUMENTARY HISTORY OF AMERICAN INDUSTRIAL SOCIETY (J. Commons ed. 1909-10); 1 P. FONER, WOMEN AND THE AMERICAN LABOR MOVEMENT 256-69 (1979).

32. See Baker, supra note 31, at 186-88, 207; De Hart-Mathews, The New Feminism and the Dynamics of Social Change, in WOMEN'S AMERICA: REFOCUSING THE PAST 437, 440 (L. Kerber \& J. De HartMathews eds. 2d ed. 1987). For historical support see generally A. KESSLER-HARRIS, OUT TO WORK: A HISTORY OF WAGE-EARNING WOMEN IN THE UNITED STATES (1982).

33. D. KATZMAN, SEVEN DAYS A WEEK: WOMEN AND DOMESTIC SERVICE IN INDUSTRIALIZING AMERICA 95-145 (1978); Blanshard, How to Live on Forty-six Cents a Day, NATION, May 15, 1929, at 530, reprinted in THE FEMALE EXPERIENCE: AN AMERICAN DOCUMENTARY 290 (G. Lerner ed. 1977); Glenn, Racial Ethnic Women's Labor: The Intersection of Race, Gender and Class Oppression, REV. RADICAL POL. ECON., Fall 1985, at 86, 92-100.

34. Compare Lochner v. New York, 198 U.S. 45 (1905) with Muller v. Oregon, 208 U.S. 412 (1908).

35. See generally W. CHAFE, supra note 30; C. DEGLER, AT ODDS: WOMEN AND THE FAMILY IN AMERICA FROM THE REVOLUTION TO THE PRESENT (1980); S. EVANS, BORN FOR LIBERTY: A HISTORY OF WORKING WOMEN IN AMERICA (1989); E. FLEXNER, supra note 20; D. RHODE, supra note 3, at 24-26; N. WOLOCH, WOMEN AND THE AMERICAN EXPERIENCE (1984).

36. See Baker, supra note 31, at 351-53. See generally U.S. WOMEN's BUREAU, U.S. DEP'T OF LABOR, BULL. NO. 65, THE EFFECTS OF LABOR LEGISLATION ON THE EMPLOYMENT OPPORTUNITIES OF WOMEN 43-53 (1928) (discussion of various protective laws). 
workers were available. By lobbying for legal protections against women on night or overtime shifts, male-dominated unions were often able to "protect" women out of the most attractive positions. ${ }^{37}$ Such statutes foreclosed occupational mobility and locked women into crowded, sex-segregated employment, which further diminished their bargaining leverage. ${ }^{38}$ Protective ideology based on women's "special needs and vulnerabilities" also spilled over to other gender discrimination contexts in which protection was less desirable, such as jury service or criminal sentencing and juvenile delinquency statutes. ${ }^{39}$

Not all of these consequences were plainly foreseeable or readily quantifiable by those who supported gender-specific regulation. In retrospect, it is by no means clear whether women gained or lost more through such initiatives. Much depends on which women and which historical periods are emphasized and what tradeoffs are made between economic and noneconomic factors. What is clear, however, is that disputes over difference did carry a substantial political cost. The issue of special treatment divided the fragile postsuffrage women's movement, part of which supported a constitutional equal rights amendment and part of which opposed any measure that would jeopardize sex-specific protections. ${ }^{40}$ As a consequence, many early twentieth-century feminists ended up fighting each other over the value of protection rather than uniting to challenge the conditions that made protection so necessary.

A second limitation in the early feminist campaign lay in its denial of the scope of the problem. To broaden their political appeal, activists increasingly narrowed their social vision. As the struggle for suffrage escalated, leaders of the organized women's movement focused ever more singlemindedly on the ballot and appealed to class, racial, and ethnic prejudices in seeking support. Female enfranchisement, it was often claimed, would be a bulwark against the

37. Equal Rights: Hearings on S.J. Res. 52 Before a Subcomm. of the Comm. on the Judiciary, 71st Cong., 3d Sess. 1, 20 (1931) (in assessing negative impact of protective labor laws and fighting for early proposed equal rights amendment the National Women's Party argued that the amendment should "require that all industrial laws be based upon the nature of the work and not upon the sex of the worker"); J. BAER, THE CHAINS OF PROTECTION: THE JUDICIAL RESPONSE TO WOMEN'S LABOR LEGISLATION 31-32 (1978); S. BECKER, THE ORIGINS OF THE EQUAL RIGHTS AMENDMENT: AMERICAN FEMINISM BETWEEN THE WARS 144-47 (1981); A. KESSLER-HARRIS, supra note 32, at 201-14; S. LEHRER, ORIGINS OF PROTECTIVE LEGISLATION FOR WOMEN 228-33 (1987); Olsen, From False Paternalism to False Equality: Judicial Assaults on Feminist Community, Illinois 1869-1895, 84 MiCH. L. REV. 1518, 1520 (1986).

38. See sources cited in Rhode, Definitions of Difference, in THEORETICAL PERSPECTIVES ON SEXUAL DIFFERENCE 197, 206-07 (D. Rhode ed. 1990) [collection as whole hereinafter THEORETICAL PERSPECTIVES].

39. For examples of women's exclusion from jury service, see Hoyt v. Florida, 368 U.S. 57, 59-65 (1961); Bailey v. State, 215 Ark. 53, 60-64, 219 S.W.2d 424, 428-29 (1949); State v. Kelley, 39 Idaho 668, 673-76, 229 P. 659, 661-62 (1924); Commonwealth v. Welosky, 276 Mass. 398, 410-11, 177 N.E. 656, 662 (1931). For criminal sentencing provisions that disadvantage women, see Ex parte Gosselin, $141 \mathrm{Me}$. $412,421-22,44$ A.2d 882, 885-86 (1945). For discussion of juvenile delinquency provisions that treated female adolescents more harshly than males, see, for example, ABA, LITTLE SISTERS AND THE LAW (1977); Moulds, Women's Crime, Women's Justice, in WOMEN, POWER, AND POLICY 205, 221-23 (E. Boneparth ed. 1982).

40. See D. RHODE, supra note 3, at 34-37. See generally S. BECKER, supra note 37; S. WARE, BEYOND SUFFRAGE: WOMEN IN THE NEW DEAL (1981) [hereinafter BEYOND SUFFRAGE]; Olsen, supra note 37. 
"brutish and ignorant Negro."41 Even after passage of the Nineteenth Amendment, when Black women demanded that America's major feminist organization, the National Women's Party, protest the denial of their voting rights in the South, the NWP refused on the grounds that this was a "'race issue,' not a 'woman's issue." "'42 Many white feminists who challenged assumptions about the inherent inferiority of women accepted analogous and equally unsupported premises about the deficiencies of the lower classes or of racial and ethnic minorities. For most activists, inequalities apart from gender were not a serious problem or not their problem. ${ }^{43}$

Feminists' focus on formal rights also deflected attention from the broader social and economic structure that constrained their exercise. Movement leaders demanded equal opportunity for women but did not envision the transformation of gender roles necessary to secure it. Although activists helped expand female participation in the public sphere, they failed to challenge the allocation of power and responsibilities in the domestic sphere. ${ }^{44}$ Nor did they focus on a range of other issues that were most crucial to those women most in need-welfare, racism, sexual violence, divorce, and birth control..$^{45}$

Of course, to have encompassed more divisive issues risked compromising support, diluting energies, and delaying the struggle for entitlements. But the price may have been higher than many women's rights advocates realized. By narrowing their definition of the problem, leaders of the early feminist movement laid foundations for its decline. Once the greatest formal disabilities had been removed, talk of emancipation and entitlements began to seem "stale stuff," a preoccupation of unfeminine "frumps" in "nondescript tweeds" who "antagonized men with their constant clamor about women's place." ${ }^{46}$ More-

41. R. FONER, FREDERICK DOUGLASS ON WOMAN'S RIGHTS 30 (1976); see also B. HOOKS, AIN'T I A WOMAN: BLACK WOMEN AND FEMINISM 130-31 (1981); G. LERNER, THE MAJORITY FINDS ITS PAST: PLACING WOMEN IN HISTORY 34 (1979).

42. S. Evans, supra note 35, at 187 (quoting Alice Paul); P. GIDDINGS, supra note 26, at 166-69.

43. For reviews of feminist leaders' class and racial bias, see, for example, S. EVANS, supra note 35, at 18; P. GIDDINGS, supra note 26, at 127-29; B. HOOKS, supra note 41, at 161-65; A. KRADITOR, supra note 20, at 141. See generally R. FONER, supra note 41; G. LERNER, supra note 41.

44. Virtually no leading nineteenth-century feminist argued that women should cease to be the primary caretakers of home and family, nor did early activists envision changes in workplace structures, male roles, and reproductive choices that would enable wives to accommcdate public and domestic life. See C. DEGLER, supra note 35, at 345-46; D. RHODE, supra note 3, at 13-14; Blackwell, Relation of Woman's Work in the Household to the World Outside, in UP FROM THE PEDESTAL: SELECTED WRITINGS IN THE HISTORY OF AMERICAN FEMINISM 150-59 (A. Kraditor ed. 1968) (proposing that women defer nondomestic achievement until age fifty at which point every vocation, including presidency, should be available to them).

45. For analysis of family violence around the turn of the century, see L. GORDON, HEROES OF THEIR OWN LIVES: THE POLITICS AND HISTORY OF FAMILY VIOLENCE 2-3 (1988). For discussion of early feminist views toward birth control, see J. MOHR, ABORTION IN AMERICA: THE ORIGINS AND EVOLUTION OF NATIONAL POLICY, 1800-1900, at 111 (1978); J. REED, FROM PRIVATE VICE TO PUBLIC VIRTUE: THE BIRTH CONTROL MOVEMENT AND AMERICAN SOCIETY 33 (1978). For issues of racism, see supra note 43. For an overview of other issues, see sources cited in D. RHODE, supra note 3, at 16-17.

46. E. SHOWALTER, THESE MODERN WOMEN: AUTOBIOGRAPHICAL ESSAYS FROM THE TWENTIES 8 (1978); G. PERRETT, AMERICA IN THE TWENTIES 158 (1982); Bromley, Feminists - New Style, HARPER's MONTHLY MAG., Oct. 1927, at 552; De Ford, The Feminist Future, THE NEW REPUBLIC, Sept. 19, 1928, at 121-23. 
over, the faith in formal entitlements obscured their practical limitations. For example, statutes granting married women equal property rights were subject to qualifications that preserved male control over family assets and reinforced traditional stereotypes about female roles. ${ }^{47}$ Since few married women had independent sources of income, property law reforms did little to reduce wives' economic dependence. Nor did sex-specific protective statutes offer adequate protection in practice. Enforcement was limited, minimum-wage requirements were set below subsistence levels, and employer exemptions were available for occupations such as domestic service and farm labor where exploitation was common and women of color were concentrated. ${ }^{48}$

The achievement of formal entitlements also had little effect on many informal barriers. ${ }^{49}$ For example, long after the elimination of sex-based admission criteria for the professions, socialization patterns, employer biases, and academic policies severely restricted the number of women, particularly women of color. ${ }^{50}$ Yale practices were typical. In 1886, its law school admitted its first woman - by mistake. When university administrators discovered that "A.B. Jordan" was female, they permitted her enrollment but adjusted the application form to prevent further embarrassment. ${ }^{51}$ Administrators at other institutions worried that the "clack of these possible Portias" would distract men and "unsex" women. ${ }^{52}$ Throughout their first century at the bar, women never exceeded $3-5 \%$ of the profession and were largely relegated to the lowest status

47. Crozier, Marital Support, 15 B.U.L. REv. 28, $37-39$ (1935); Johnston, Sex and Property: The Common Law Tradition, The Law School Curriculum, and Developments Toward Equality, 47 N.Y.U. L. REV. 1033, 1070-89 (1972). See generally N. BASCH, IN THE EYES OF THE LAW: WOMEN, MARRIAGE, AND PROPERTY IN NINETEENTH-CENTURY NEW YORK (1982); Chused, Married Women's Property Law: 18001850,71 GEO. L.J. 1359 (1983); Speth, The Married Women's Property Acts 1839-1865: Reform, Reaction, or Revolution?, in 2 WOMEN AND THE LAW, supra note 21, at 69.

48. J. BAER, supra note 37, at 31-32; L. SCHARF, TO WORK AND TO WED: FEMALE EMPLOYMENT, FEMINISM, AND THE GREAT DEPRESSION 114, 116 (1980); Note, Regulation of Conditions of Employment of Women: A Critique of Muller v. Oregon, 13 B.U.L. REV. 276, 289-90 (1933).

49. B. Lockwood, My Efforts to Become a Lawyer, in WOMEN IN THE AMERICAN ECONOMY: A DOCUMENTARY HISTORY, 1675 TO 1929 , at 297-98 (W. Brownlee \& M. Brownlee eds. 1976). Throughout the first half of the twentieth century, women never constituted more than about $7 \%$ of any of the elite professions. B. HARRIS, supra note 17, at 137-39; Degler, Revolution Without Ideology: The Changing Place of Women in America, in THE WOMAN IN AMERICA 193, 201 (R. Lifton ed. 1965). For other statistics on women's underrepresentation in public life during in the first half of the century, see E. FLEXNER, supra note 20, at 325; B. HARRIS, supra note 17, at 156; J. POLE, THE PURSUIT OF EQUALITY IN AMERICAN HISTORY 311 (1978). See generally sources cited supra note 35. For statistics on women of color, see generally G. SEGAL, BLACKS IN THE LAW (1983); A. MIRANDE \& E. ENRIQUEZ, supra note 26; K. MORELLO, THE INVISIBLE BAR: THE WOMAN LAWYER IN AMERICA: 1638 TO THE PRESENT 143-73 (1986); Parker \& Stebman, Legal Education for Blacks, ANNALS, May 1973, at 144.

50. K. MORELLO, supra note 49, at 3-39; see also R. STEVENS, LAW SCHOOL: LEGAL EDUCATION IN AMERICA FROM THE 1850S TO THE 1980s, at 82-84 (1983); Bittenbender, Woman in Law, in WOMAN's WORK IN AMERICA 220-44 (A. Meyer ed. 1972). On barriers confronting women of color, see K. MORELLO, supra note 49, at 143-73; G. SEGAL, supra note 49; Parker \& Stebman, supra note 49.

51. Schiff, Old Yale: The Earliest Women, YALE ALUMNI MAG., Dec. 1989.

52. See sources cited in Rhode, supra note 38, at 206-07 n.37; supra note 50. 
areas of practice..$^{53}$ Not until 1972 did all bar-accredited law schools admit female students. ${ }^{54}$

These limitations in the early women's movement should not, however, obscure its contributions. For the first time, feminists made gender inequality a social problem demanding political recognition and legal reform. As a consequence, women gained rights essential to contest their subordinate status. Yet for the next half-century, they failed to exercise those rights in ways that would materially improve their lives. For the most part, women neither organized around women's issues nor confronted the ideology of difference that made such organization necessary. ${ }^{55}$ The limitations, as well as the accomplishments, of early feminist struggles hold lessons for their contemporary counterparts.

\section{B. Contemporary Frameworks}

\section{The Cultural Context}

By the 1960's, traditional gender roles were growing increasingly out of step with socioeconomic, demographic, and technological forces. After the postwar baby boom, the development of effective oral contraceptives contributed to a longstanding decline in birth rates. This decline, coupled with the rise in women's life expectancy, meant that the average mother could anticipate spending about two-thirds of her adult years with no children under the age of eighteen. ${ }^{56}$ Marriage, like motherhood, was also becoming a less stable foundation on which to build an entire life. At the turn of the century, one in 500 marriages ended in divorce; by the 1960's, the ratio was about one in three, and current estimates are one in two..$^{57}$

53. C. EPSTEN, WOMEN IN LAW 49-94 (1981); B. HARRIS, supra note 17, at 108-09, 138; Rhode, Perspectives on Professional Women, 40 STAN. L. REV. 1163, 1173-74 (1988).

54. C. EPSTEIN, supra note 53, at 50-55; B. HARRIS, supra note 17, at 108-09, 138; Fossum, Women in the Legal Profession: A Progress Report, 67 WOMEN LAW. J. 1, 1 (1981).

55. See generally W. CHAFE, supra note 30; N. COTT, THE GROUNDING OF MODERN FEMINISM (1987); C. DEGLER, supra note 35. Women did, however, make some important gains through social welfare activity and increased representation in political positions. BEYOND SUFFRAGE, supra note 40; S. WARE, HOLDING THEIR OWN: AMERICAN WOMEN IN THE 1930s (1982); Stricker, Cookbooks and Law Books: The Hidden History of Career Women in Twentieth-Century America, in A HERITAGE OF HER OWN: TOWARD A NEW SOCIAL HISTORY OF AMERICAN WOMEN 476, 479 (N.Cott \& E. Pleck eds. 1979).

56. J. BARDWICK, IN TRANSITION: HOW FEMINISM, SEXUAL LIBERATION, AND THE SEARCH FOR SELFFULFILLMENT HAVE ALTERED OUR LIVES 65 (1979); see also AMERICAN WOMEN: REPORT OF THE PRESIDENT'S COMMISSION ON THE STATUS OF WOMEN 4-7 (1963) [hereinafter REPORT OF THE PRESIDENT'S COMMISSION]; E. KLEIN, GENDER POLITICS 66-67 (1984); M. RYAN, WOMANHOOD IN AMERICA: FROM Colonial Times to the PREsent 279-80 (1983); G. YATES, What WOMEN WANT: THE IDEAS OF THE MOVEMENT 155 (1975) (quoting A. Rossi, Family Development in a Changing World (paper presented at the annual meeting of the American Psychiatric Association (May 5, 1970))).

57. See J. BARDWICK, supra note 56, at 100; A. CHERLIN, MARRIAGE, DIVORCE, REMARRLAGE 21-25 (1981); G. MASNICK \& M. BANE, THE NATION's FAMILIES 1960-1990, at 31-37 (1980). 
This escalating divorce rate, coupled with a rise in nonmarital childbirth, increased women's need for economic independence and paid employment. High inflation and rising expectations in living standards also encouraged more women to enter the labor force for longer periods. ${ }^{58}$ This trend was not without precedent; many women of color had always worked and World War II had brought a substantial percentage of white women into the paid labor force..$^{59}$ But the growth in female employment beginning in the 1960's was more widespread and sustained. As increasing numbers of women workers encountered gender-based restrictions, the foundations for feminist activity grew stronger.

These structural forces both responded and contributed to changes in the ideological climate. During the 1960's and early 1970's, the growth in progressive political movements, and the discrimination that women experienced within them, fueled demands for a broader transformation of gender roles. ${ }^{60}$ So too, the frustrations of many middle-class housewives, trapped in menial tasks and vicarious relationships, found expression in feminist publications and discussion groups. What Betty Friedan labeled "the problem that has no name" began to gain recognition. ${ }^{61}$ In less than a decade, the women's movement transformed "personal" issues into political causes and reconceptualized individual grievances as social injustices.

Over the next quarter-century, feminist strategies sought to change consciousness and change laws. Legal efforts focused on expanding reproductive freedom, deterring sexual abuse, and eliminating sex-based discrimination in employment, education, family, welfare, and related contexts. The objective was to challenge unequal opportunities and the ideology that had legitimated them.

Such efforts, like those of the first feminist campaign, have resulted in partial progress. Women have increasingly secured equality in formal rights, but as noted earlier, they still experience substantial inequalities in social, economic, and political status. The persistence of such disparities is in part attributable to the continuing devaluation of women's capabilities and women's work. Such devaluation is most obvious in New Right ideology and sociobiolo-

58. J. GIELE, WOMEN AND THE FUTURE: ChANGING SEX ROLES IN MODERN AMERICA 92 (1978); REPORT OF THE PRESIDENT'S COMMISSION, supra note 56, at 58-60; M. RYAN, supra note 56, at 280; Bird, The Androgynous Life, in VOICES OF THE NEW FEMDNSM 178, 190-98 (M. Thompson ed. 1970). This is not to imply that escalating divorce rates were the preeminent cause of women's increased labor force participation. For many women, increased access to paid employment made divorce possible.

59. J. JONES, supra note 26; V. OPPENHEIMER, THE FEMALE LABOR FORCE IN THE U.S. (1970); W. WANDERSEE, WOMEN'S WORK AND FAMILY VALUES, 1920-1940 (1981); N. WOLOCH, supra note 35, at 505-08.

60. For descriptions of sex-based subordination in civil rights, antiwar, and other left groups, see $S$. EVANS, PERSONAL POLITICS: THE ROOTS OF WOMEN'S LIBERATION IN THE CIVIL RIGHTS MOVEMENT AND THE NEW LEFT (1979); J. HOLE \& E. LEVINE, REBIRTH OF FEMINISM (1971).

61. B. FRIEDAN, THE FEMININE MYSTIQUE 15 (1983) (1963); see also J. CHAFETZ, supra note 9, at 163-70 (describing how macrostructural changes open opportunities for women that create role conflicts, encourage a sense of relative deprivation, and increase gender consciousness). 
gical theory, but it also appears in less explicit or conscious forms in a broad array of other contexts.

\section{Conservative Ideology: Religious and Sociobiological Premises}

As was true a century earlier, nature and the Creator figure prominently in conservative justifications of sex-based inequality. Both biology and theology continue to frame debates over a range of legal issues involving abortion, employment, welfare and family policy, gay/lesbian rights, and a proposed constitutional Equal Rights Amendment (ERA).

For example, opposition to the Amendment drew heavily on Fundamentalist and Catholic constituencies, which viewed gender equality as inconsistent with scriptural authority. As one Montana legislator informed his colleagues, if God "had wanted women to be equal, He would have had six female apostles."62 According to Phyllis Schlafly, leader of the anti-ERA campaign, the "Divine Architect" created fundamental biological differences between the sexes, from which fundamental social inequalities necessarily follow. ${ }^{63}$ By her reasoning, "[w]omen have babies, so men should support them." ${ }^{64}$ To New Right leaders, it generally seems self-evident that "most women would rather cuddle a baby than a typewriter or factory machine" and are willing to place family over career. ${ }^{65}$ Under this view, the centrality of the male's breadwinning role justifies his dominance in both work and family settings. ${ }^{66}$

Other conservative leaders, while less explicit about sex-based hierarchies, generally endorse the role division underlying them. Pope John Paul II's 1988

62. J. BOLES, THE POLITICS OF THE EQUAL RIGHTS AMENDMENT: CONFLICT AND THE DECISION PROCESS 6 (1979); see also A. DWORKIN, RIGHT-WING WOMEN 117 (1983) (describing views of Christian woman from Mississippi on ERA); O'Reilly, Every Woman Has Become Feminist in Her Own Way, Chi. Tribune, June 27, 1982, $\S 2$, at 1 , col. 3. In a more recent example of similar logic, Bob Knepper, Houston Astros pitcher, objected to women umpires on the grounds that "[ $t]$ his is not an occupation women should be in. In God's society, woman was created in the role of submission to the husband. It's not that woman is inferior, but I don't believe women should be in a leadership role." Lieber, Some Say No Leica, SPORTS ILLUSTRATED, June 20, 1988, at 48.

For accounts of ERA opposition by religious groups, see P. CONOVER \& V. GRAY, FEMINISM AND THE NEW RIGHT: CONFLICT OVER THE AMERICAN FAMILY (1983); Brady \& Tedin, Ladies in Pink: Religion and Political Ideology in the Anti-ERA Movement, 56 SOC. SCI. Q. 564, 573-75 (1976); Rhode, Equal Rights in Retrospect, 1 J.L. \& INEQUALTY 1, 36-37 (1983); Swidler, Catholics and the E.R.A., 103 COMMONWEAL 585 (1976).

63. P. SCHLAFLY, THE POWER OF THE POSITIVE WOMAN 12-17 (1977).

64. Loercher, Equality for Women Stalled?, Christian Sci. Monitor, Feb. 15, 1973, at 6, col. 2 (quoting Schlafly).

65. P. SCHLAFLY, supra note 63, at 51-52; see also R. KLATCH, WOMEN OF THE NEW RIGHT 191 (1987) (quoting one conservative woman's assumption that "very few people have a job more pleasant than taking care of their own children"); infra note 123.

66. Since a family "cannot be run by committee," it needs an "ultimate decisionmaker, and that is the husband." P. SCHLAFLY, supra note 63, at 50; see also S. ALI, THE BLACKMAN's GUIDE TO UNDERSTANDING THE BLACKWOMAN (1990); R. KLATCH, supra note 65, at 146 (quoting C. MARSHNER, THE NEW TRADITIONAL WOMAN 6 (Free Congress Res. \& Educ. Found. ed. 1982)). 
Apostolic Letter echoed traditional nineteenth-century assumptions about the sexes" "separate spheres":

In the name of liberation from male domination, women must not appropriate to themselves male characteristics contrary to their feminine "originality." There is a well founded fear that if they take this path, women will not reach fulfillment but instead will deform ... their essential richness.... Parenthood, although it belongs to both-is realized more fully in the woman. Motherhood involves a special communion with the mystery of life ... which profoundly marks the woman's personality. ${ }^{67}$

Other conservatives arrive at similar conclusions through more secular routes. Some draw on sociobiological accounts of gender hierarchy. According to these theorists, "Mother Nature is sexist." ${ }^{68}$ Males' and females' different reproductive physiologies are reportedly responsible for sex-based distinctions in aggression and parental responsibilities. From these basic distinctions others emerge. ${ }^{69}$ As E.O. Wilson explains, "[t]he physical and temperamental differences between men and women have been amplified by culture into male dominance. History records not a single society in which women have controlled the political and economic lives of men."70 Although some sociobiologists, including Wilson, acknowledge that societies could "probably cancel" the consequences of sex-based difference, they warn that such a project would require "a conscious decision based on fuller and more exact knowledge than is now available."71

Despite extensive evidence undermining sociobiological premises, their proponents have retained influence in conservative circles. ${ }^{72}$ Females' absence

67. Excerpts from Pope John Paul II's Apostolic Letter, N.Y. Times, Oct. 1, 1988, § 1, at 6, col. 2. For discussion of how the Mormon Church's similar support for traditional gender roles affects women's legal and social status, see UTAH TASK FORCE ON GENDER \& JUSTICE, REPORT TO THE UTAH JUDICIAL COUNCIL 14-15, 34, 98 (1990) [hereinafter UTAH TASK FORCE].

68. D. BARASH, THE WHISPERINGS WITHIN (1979), quoted in Hubbard, Social Effects of Some Contemporary Myths About Women, in WOMAN's NATURE: RATIONALIZATIONS OF INEQUALITY 1, 6 (M. LOWe \& R. Hubbard eds. 1988).

69. See, e.g., R. DAWKINS, THE SELFISH GENE 152-55 (1976). Dawkins, like Edward Wilson, views the relative size of sex cells, or gametes, as central to sex-based subordination. The egg is relatively large, and contains the yolk that nourishes the embryo during early development, while the sperm is relatively small, mobile, and easily replicated. Since "each sperm is so tiny, a male can afford to make millions of them every day" and "beget a large number of children in a very short period of time." Id. at 152. By contrast, the female has greater responsibilities to each embryo; "[f]emale exploitation begins here." Id.; see also E.O. WILSON, SOCIOBIOLOGY 156 (abr. ed. 1980).

70. E.O. WILSON, ON HUMAN NATURE 128 (1978); see also sources cited supra note 69; infra notes $71 \& 73$.

71. E.O. WILSON, supra note 70 , at 133-34. Other commentators deny that any cultural interventions could be successful; in their view, "it is impossible to overcome the biological inevitability of sex roles, but it is possible to try-and to violate fundamental liberal values [of liberty and autonomy] in the process." M. LEVIN, FEMINISM AND FREEDOM 3 (1987); see also sources cited supra note 69.

72. For critical reviews, see generally L. BIRKE, WOMEN, FEMINISM AND BIOLOGY: THE FEMINIST Challenge (1986); R. BLEIER, SCIENCE AND GENDER: A CRITIQUE OF BIOLOGY AND ITS THEORIES ON WOMEN (1984); A. FAUSTO-STERLING, MYTHS OF GENDER: BIOLOGICAL THEORIES ABOUT MEN AND 
from the ranks of chess grand masters, computer experts, and national political leaders have all been attributed to "natural" causes: raging hormones, spatial incapacities, and inadequate testosterone. ${ }^{73}$ To many observers, it is hardly coincidental that the Japanese firms dominating technological markets are almost exclusively male. ${ }^{74}$ Scholars applying sociobiological frameworks to legal doctrine have counseled against "attempting to achieve an androgynous society through antidiscrimination laws." 75 In their view, sex-based distinctions are appropriate on issues ranging from the exclusion of women in aggressive roles such as military combat to the exclusion of men from caretaking roles such as flight attendants or custodians of small children. ${ }^{76}$ With similar reasoning, New Right theorists assert the "inevitability of patriarchy" and warn that policies challenging traditional gender norms can only result in "sexual suicide" and cultural chaos. ${ }^{77}$

Although explicit assertions of female inferiority appear with declining frequency, their influence cannot be entirely discounted. According to recent public opinion polls, a majority of Americans believe that most men think they are "better" than women. ${ }^{78}$ About a third of surveyed adults view masculine and feminine characteristics as biologically based, and an equal percentage of women express support for traditional male breadwinner/female homemaker roles. ${ }^{79}$ Substantially larger percentages of both women and men believe that husbands' careers should take priority over wives' and that husbands need not

WOMEN (1984); E. LEACOCK, MYTHS OF MALE DOMINANCE (1981); Hubbard, The Political Nature of "Human Nature," in THEORETICAL PERSPECTIVEs, supra note 38, at 63; Kay, Perspectives on Sociobiology. Feminism, and the Law, in THEORETICAL PERSPECTIVES, supra note 38, at 74.

73. See, e.g., Gilder, The Myth of the Role Revolution, in GENDER SANITY 230 (N. Davidson ed. 1989) [collection as whole hereinafter GENDER SANITY]; Hare-Mustin \& Marecek, On Making a Difference, in MAKING A DIFFERENCE: PSYCHOLOGY AND THE CONSTRUCTION OF GENDER 1, 10 (1990) [collection as whole hereinafter MAKING A DIFFERENCE]; see also Christen, Sex Differences in the Human Brain, in GENDER SANITY, supra, at 150 (arguing that men are more gifted in perceiving physical world and women more gifted in social relations, and that such differences explain vocational differences, such as women's ability to assemble watches but not to design or repair them).

74. Gilder, supra note 73 , at 234 ; see also other sources cited supra note 73 and sources cited infra note 77.

75. Browne, Biology, Equality, and the Law: The Legal Significance of Biological Sex Differences, 38 Sw. L.J. 617, 619 (1984).

76. See J. BECKSTROM, SOCIOBIOLOGY AND THE LAW: THE BIOLOGY OF ALTRUISM IN THE COURTROOM OF THE FUTURE 75-92 (1985); Beckstrom, The Potential Dangers and Benefits of Introducing Sociobiology to Lawyers, 79 NW. U.L. REV. 1279, 1288-92 (1984). See generally Kay, supra note 72, at 78-80 (providing critique of such theories).

77. See generally N. DAVIDSON, THE FAILURE OF FEMINISM (1988); G. GILDER, MEN AND MARRIAGE (1986); G. GILDER, SEXUAL SUICIDE (1973); S. GOLDBERG, THE INEVITABILITY OF PATRIARCHY (1973). For critical reviews, see Z. EISENSTEIN, FEMINISM AND SEXUAL EQUALITY (1984).

78. Belkin, Bars to Equality of Sexes Seen as Eroding. Slowly, N.Y. Times, Aug. 20, 1989, § 1, at 1, col. 1 ( $53 \%$ of women and $48 \%$ of men believe men consider themselves superior).

79. ROPER ORG., THE VIRGINIA SLIMS AMERICAN WOMEN'S POLL 27-28 (1985) [hereinafter VIRGINIA SLIMS POLL] (23\% of respondents believed that basic physical differences caused masculine and feminine behavior and another $16 \%$ felt that both physical differences and childrearing patterns were responsible); Destefano \& Colasanto, Most Believe U.S. Men Have a Better Life, San Francisco Chron., Feb. S, 1990, at B5, col. 5 . 
share evenly in family responsibilities. ${ }^{80}$ About half of surveyed women also consider women inferior for certain occupations ranging from airline pilot to combat soldier. ${ }^{81}$

Debates over female participation in the armed forces offer a representative array of gender stereotypes. According to legislators such as Webber Borchers of Illinois, the nation can ill afford women soldiers whose "inadequate hip structure," "tender [feet]," and hesitance to "press the attack" would "hamstring the infantry." During the Persian Gulf conflict, some military officers complained that female involvement was a "pain in the butt." There was no point having a lot of women around "doing nothing" except "distracting men" since "it is pretty clear that they can't accomplish as much as a man and can't compete in strength." 82 The assignment of women even to button-pushing positions has appeared an unnecessary "gamble" given sex differences in aggression and interpersonal concerns, namely females' greater likelihood of "see[ing] their target[s] as people," and males' demonstrably greater willingness to "kill impersonally." 83

The stereotypes underlying these assumptions appear largely unaffected by evidence. Despite the declining importance of physical strength in modern warfare, and the increasing data on female effectiveness in combat, simulated combat, and related police and prison contexts, legal decisionmakers have

80. For example, when asked about a hypothetical situation in which a husband and wife with no children both have good jobs and the husband receives a "very good" job offer in another city, over 71\% of the women felt that the wife should relocate. Where the situation was reversed and the wife received the offer, only $21 \%$ felt that the husband should relocate. See 1985 VIRGINIA SLIMS POLL, supra note 79, at 28; see also A. HOCHSHIDD \& A. MACHUNG, THE SECOND SHIFT: WORKING PARENTS AND THE REVOLUTION AT HOME 266 (1989) (half of surveyed women plan to put their husband's job first; two thirds of men plan to put their own job first).

For attitudes concerning husband's family obligations, see J. PLECK, WORKING WIVES/WORKING HUSBANDS 33, 44-45, 90-92 (1985) (finding that wives do substantially more domestic work than husbands but only about a third express desire for husbands to do more); Cowan, Women's Gains on the Job: Not Without a Heavy Toll, N.Y. Times, Aug. 21, 1989, at A1, col. 1, A14, col. 4 (only 27\% of wives felt that husbands did less than "fair share" in the house but studies find that women do twice as much housework as men); infra Part IV.A.1.

81. See sources cited supra note 73 and infra notes 82-83; 1985 VIRGINIA SLIMS POLL, supra note 79, at 35. For example, $50 \%$ of a male sample in a Virginia Slims Poll had more confidence in a male policeman and $49 \%$ in a male pilot. Id. Within the engineering profession, there appears wide acceptance of the claim that "male dominance is almost certainly due to the males' cognitive advantage rather than to a culturally induced female disadvantage." M. LEVIN, supra note 71, at 99; see also C. COCKBURN, MACHINERY OF DOMINANCE: WOMEN, MEN AND TECHNICAL KNOW-HOW 165-72 (1985).

82. Bishop, The Gulf War: Women Marines Philosophical Before the Fray, Daily Telegraph, Jan. 26, 1991, at 3; Royco, Borchers Hip to Girl Power, Chi. Daily News, Mar. 26, 1973, at 12, col. 1; see also Crisis in the Gulf: Women's Place at the Front Provokes Fears at Home, The Independent, Feb. 4, 1991, at 3 (quoting claim of Brian Mitchell, author of WEAK LINK: THE FEMINIZATION OF THE AMERICAN MILITARY (1988), that "[h]alf the women in the Marine Corps cannot throw a grenade far enough to avoid injuring themselves"). For other concerns, see sources cited in D. RHODE, supra note 3, at 67, 100; infra text accompanying note 83 .

83. M. LEVIN, supra note 71, at 239; see also Webb, Women Can't Fight, in GENDER SANITY, supra note 73 , at 208 . 
largely refused to apply antidiscrimination principles to military service. ${ }^{84}$ That refusal both affirms and extends the continued legacy of traditional stereotypes.

\section{Gender Bias: Academic and Employment Settings}

In other contexts, assumptions about female inferiority draw less directly on religious or sociobiological premises and operate at less conscious levels. Gender restrictions in educational institutions are a case in point. Although most public justifications of single-sex schools have presented them as "separate but equal," about the "equal." During the early 1970's, Harvard's Director of Admissions explained that sex-blind policies were undesirable because they would require reductions in the number of male students to accommodate women, and that would mean "less diversity in the class and, as a result, fewer interesting people." 86 Opponents of coeducation at Yale expressed related concerns. As one professor put it, "I feel a greater sense of accomplishment when I direct my efforts toward those who will one day have a greater role than women in society." would want to concentrate on the basic principles of thermodynamics," but would instead be distracted by steady dates "trying to gossip about all the idiotic trivia all women try to impose on men."

Yet despite such attitudes, legal decisionmakers have generally declined to interfere with admission policies at all-male institutions. ${ }^{89}$ Federal civil rights law expressly permits sex-based admissions by traditionally single-sex private schools, and federal courts have consistently sustained such practices at all-male public institutions. ${ }^{90}$ Thus, recent trends toward coeducation have occurred

84. See Rostker v. Goldberg, 453 U.S. 57 (1981) (upholding male-only registration system for military service). For analysis of women's effectiveness in military and related contexts, see M. BINKIN \& S. BACH, WOMEN AND THE MILITARY 81-91 (1977); L. LAFLIN, WOMEN IN BATTLES 10, 22, 62-79 (1968); H. ROGAN, MIXED COMPANY: WOMEN IN THE MODERN ARMY 258 (1981); J. STIEHM, BRING ME MEN AND WOMEN: MANDATED CHANGE AT THE U.S. AIR FORCE ACADEMY 129-30, 167, 199, 250 (1981); Kornblum, Women Warriors in a Men's World: The Combat Exclusion, 2 J.L. \& INEQUALITY 351, 395-428 (1984); Sayers, Science, Sexual Difference, and Feminism, in ANALYZING GENDER: A HANDBOOK OF SOCLAL SCIENCE RESEARCH 68, 85 (B. Hess \& M. Ferree eds. 1987) [collection as whole hereinafter ANALYZING GENDER].

85. D. RHODE, supra note 3, at 274, 288-98; 2 T. WOODY, supra note 16, at 151-53, 210, $271-79$.

86. As quoted in Zinberg, College: When the Future Becomes the Present, in WOMEN AND SUCCESS 129, 131 (R. Kundsin ed. 1974).

87. J. LeVer \& P. SChWARTZ, Women at Yale: Liberating a College CaMpus 35 (1971).

88. As quoted in id.

89. For three centuries the exclusion of women from public and private institutions passed without judicial objection. See, e.g., Vorchheimer v. School Dist., 532 F.2d 880 (3d Cir. 1976), aff'd by an equally divided court, 430 U.S. 703 (1977); Kirstein v. Rector, 309 F. Supp. 184 (E.D. Va. 1970); Heaton v. Bristol, 317 S.W.2d 86, 100 (Tex. Civ. App. 1958), cert. denied, 359 U.S. 230 (1959); Allred v. Heaton, 336 S.W.2d 251, 261 (Tex. Civ. App. 1960), cert. denied, 364 U.S. 517 (1960).

90. Title IX, barring sex discrimination by federally funded programs, included an exception for public undergraduate institutions that had traditionally and continuously maintained single-sex admission policies. See 20 U.S.C. § 1703(a) (1982). Certain sections of the Equal Educational Opportunities Act that apply to elementary and secondary education omit sex from the list of prohibited discriminations; other sections include sex. See Vorchheimer v. School Dist., 532 F.2d at 880 . Ironically, the only case in which the 
largely without legal impetus. Nor has the promotion of gender equality been a primary motivating factor. Rather, administrators at all-male institutions worried that they could not retain educational prominence or financial stability if they continued to exclude not only all qualified female candidates but also the rising number of male applicants who preferred a gender-integrated environment. ${ }^{91}$ At graduate and professional schools, female representation increased when the Vietnam War reduced the number of male applicants. Only at that point did many educators find it necessary to admit those whom Harvard President Nathan Pusey characterized as "the blind, the lame, and the women." 92

If gender equality has not been a principal impetus for coeducation, neither has it been a necessary result. Again, much of the current problem reflects denials that a problem persists. Women's increasing presence has often been taken as testament that equal treatment has been achieved. Yet recent surveys reveal continued biases in classroom interaction, instructional materials, vocational preparation, and personnel practices. ${ }^{93}$

Legal education is no exception. Sex bias in standard texts and curricular offerings remains common. Teaching materials frequently retain demeaning stereotypes of women as credulous consumers, irrational jurors, and passive victims. ${ }^{94}$ Rarely are the sentiments quite as explicit as in one prominent casebook's assertion that "land, like woman, was meant to be possessed." 95 More often the problem is inattention. Women's voices are often silenced in the classroom just as "women's issues" are often omitted from the curriculum. ${ }^{96}$ Comments by female students and faculty are more likely to be dis-

Supreme Court has struck down gender-exclusive policies involved bans against male, not female, applicants. Mississippi Univ. for Women v. Hogan, 458 U.S. 718, 745 (1982).

91. J. LEVER \& P. SCHWARTZ, supra note 87, at 58.

92. As quoted in Harris, The Second Sex in Academe, 56 A.A.U.P. BuLL. 283, 283 (1970).

93. See B. SANDLER \& R. HALL, The CaMPus Clmate Revistred: ChILlY FOR WOMEN Faculty, ADMINISTRATORS AND GRADUATE STUDENTS 13 n.5, 67-69 (1986); D. TYACK \& E. HANSOT, LEARNING TOGETHER: A HISTORY OF COEDUCATION IN AMERICAN SCHOOLS 250-77 (1990); Karp \& Yoels, The College Classroom: Some Observations on the Meanings of Student Participation, 60 SOC. \& SOC. RES. 421 (1976); Fiske, Lessons, N.Y. Times, Apr. 11, 1990, at B8, col. 1.

94. See Banks, Gender Bias in the Classroom, 38 J. LEGAL Educ. 137, 138-43 (1988); Coombs, Crime in the Stacks, or a Tale of a Text: A Feminist Response to a Criminal Law Textbook, $38 \mathrm{~J}$. LEGAL Educ. 117 (1988); Elkins, On the Significance of Women in Legal Education, 7 A.L.S.A.F. 290 (1984); Erickson, Final Report, Sex Bias in the Teaching of Criminal Law Casebooks, 42 RUTGERS L. REv. 309 (1990); Erickson, Sex Bias in Law School Courses: Some Common Issues, 38 J. LEgAL EDUc. 101, 105 (1988) [hereinafter Sex Bias in Law School Courses]; Frug, Re-Reading Contracts: A Feminist Analysis of a Contracts Casebook, 34 AM. U.L. REV, 1065 (1985).

95. C. BERGER, LAND OWNERSHIP AND USE: CASES, STATUTES AND OTHER MATERIALS 139 (1968), quoted in Ginsburg \& Flagg, Some Reflections on the Feminist Legal Thought of the 1970s, 1989 U. CHI. LEGAL F. 9. The genre is not entirely extinct, see, e.g., E. RABIN, FUNDAMENTALS OF MODERN REAL PROPERTY LAW, at Xx (2d ed. 1982) ("Property law, like pornography, has something for everyone.").

96. Homer \& Schwartz, Admitted but Not Accepted: Outsiders Take an Inside Look at Law School, 5 BERKELEY WOMEN's L.J. 1 (1990); Weiss \& Melling, The Legal Education of Twenty Women, 40 STAN. L. REV. 1299 (1988); Project, Gender, Legal Education, and the Legal Profession, 40 STAN. L. REV. 1209 (1988). 
counted, dismissed, interrupted, or misattributed than those of male colleagues. ${ }^{97}$ Empirical surveys at Yale and other law schools have quantified female students' discontent and disengagement under adversarial styles of legal education. ${ }^{98}$

While contemporary feminism has succeeded in putting these issues on the agenda, its project is by no means complete. Women hold fewer than $15 \%$ of tenured academic posts, women of color have barely reached even token levels, and most law schools still offer no course on sex-based discrimination. Fewer still give any attention to issues of sexual orientation. ${ }^{99}$ Too many reforms have rested with an "add woman and stir" approach-a single elective course offering, or an occasional obligatory reference to "women's issues." Too few initiatives have undertaken what is truly required, a fundamental reassessment of academic premises and priorities.

Any adequate response to gender bias will require a more central role for values traditionally associated with women. That, in turn, implies less competitive and combative forms of legal education and more attention to concerns of subordinate groups. Development of empathetic skills, cooperative opportunities, and participatory styles of interaction must become higher priorities. ${ }^{100}$ Writing about women's issues, counseling women students, and reserving time for "women's work" in family settings must become more compatible with career advancement. Analogous changes have to extend beyond faculty and students to employees who are less privileged members of the law school community. Educational institutions, like other employment settings, need restructuring to promote a more caring work environment, to accommodate greater family commitments, and to ensure greater inclusion of minority groups. The objective, as Virginia Woolf once emphasized, is not for women simply to "join the academic procession," but also to rethink its direction. ${ }^{101}$

97. See sources cited supra note 96. For similar patterns in other academic contexts, see LANGUAGE, GENDER, AND SOCIETY (B. Thorne, C. Kramarae \& N. Henley eds. 1983); sources cited supra note 93.

98. See Banks, supra note 94; Homer \& Schwartz, supra note 96; Weiss \& Melling, supra note 96.

99. For women's underrepresentation in higher status and higher paying positions, see Chused, The Hiring and Retention of Minorities and Women on American Law School Faculties, 137 U. PA. L. REV. 537, 548-55, 557 table II (1988); Thorner, Gender and the Professions: The Search for Equal Access, 4 GEO. J. LEGAL ETHICS 81, 90-92 (1990). For the absence of sex discrimination courses, see Sex Bias in Law School Courses, supra note 94, at 103. For the absence of sexual orientation courses, see Miller, The Legal Closet, 16 STUDENT LAW. 12, 14 (1988).

Women of color confront devaluation on two fronts and their small numbers in most academic settings makes such preconceptions especially difficult to challenge. See sources cited in J. FERNANDEZ, RACISM AND SEXISM IN CORPORATE LIFE: CHANGING VALUES IN AMERICAN BUSINESS 107 (1981); Y. MOSES, BLACK WOMEN IN ACADEME: ISSUES AND STRATEGIES 3-6 (1989); Homer \& Schwartz, supra note 96, at 21-22, 33-46.

100. For discussion of the value of empathy as epistemological technique, see M. BELENKY, B. Clinchy, N. GoldBerger \& J. TARULE, WOMEN'S WAYS OF KNOWING (1986); Held, Feminism and Epistemology: Recent Work on the Connection Between Gender and Knowledge, 14 PHL. \& PUB. AFF. 296, 306-07 (1985). For discussion of alternative classroom styles, see Crenshaw, Foreword: Toward a RaceConscious Pedagogy in Legal Education, 11 NAT'L BLACK L.J. 1 (1989); Wildman, The Question of Silence: Techniques to Ensure Full Class Participation, 38 J. LEGAL EDUC. 147 (1988).

101. V. WOOLF, THREE GuINEAS 62-63 (1938). 
Related sex-based biases arise in a wide variety of other contexts, and present related challenges. Despite substantial recent changes in gender roles, gender stereotypes have remained remarkably resilient. ${ }^{102}$ For example, the same resumes, scholarly articles, or artistic works are rated lower when they are attributed to a woman rather than a man. ${ }^{103}$ Females' performance in negotiation and experimental tasks is evaluated less favorably than males' even when objective outcomes are the same. ${ }^{104}$ Compared with men, women tend to rate their own work more harshly, and are less likely to take credit for favorable results. ${ }^{105}$ Since studies involving racial bias reveal similar patterns, women of color face special obstacles. For them, the paradox of too little and too much attention is especially pronounced; their positive contributions are most often overlooked and their mistakes most often noticed. ${ }^{106}$

Gender socialization patterns also leave many women workers in a familiar double bind; they are criticized for being "too feminine" or not "feminine enough." 107 What is viewed as assertive in a man is abrasive in a woman. Given the inconsistency between traits associated with femininity and those associated with vocational achievement, female performance is frequently undervalued. Unconscious bias affects evaluations not only of women's abilities

102. A. EAGLY, SEX DIFFERENCES IN SOCIAL BEHAVIOR: A SOCIAL-ROLE INTERPRETATION 31 (1987); Ruble \& Ruble, Sex Stereotypes, in IN THE EYE OF THE BEHOLDER: CONTEMPORARY ISSUES IN STEREOTYPING 188, 228 (A. Miller ed. 1982). See generally G. POWELL, WOMEN AND MEN IN MANAGEMENT (1985).

103. Lott, The Devaluation of Women's Competence, 41 J. Soc. IssuES, No. 4, 1985, at 43, 50; Nieva \& Gutek, Sex Effects on Evaluation, 5 ACAD. MGMT. REV. 267, 273 (1980) (pro-male bias most likely where inferences are required, where sex-role incongruity appears, and high level of performance or qualification is required); Paludi \& Bauer, Goldberg Revisited: What's in an Author's Name, 9 SEX ROLES 387 (1983); Paludi \& Strayer, What's in an Author's Name? Differential Evaluations of Performance as a Function of Author's Name, 12 SEX ROLES 353 (1985); Ruble \& Ruble, supra note 102, at 205-07.

104. See D. Kolb \& G. CoOlidge, Her Place at the Table: A Consideration of Gender Issues IN NEgotration 23 (Harvard Program on Negotiation Working Paper Series No. 88-5, 1988); Deaux, From Individual Differences to Social Categories: Analysis of a Decade's Research on Gender, 39 AM. PSYCHOLOGIST 105, 110-11 (1984). For similar patterns in other contexts, see generally V. NIEVA \& B. GUTEK, WOMEN AND WORK: A PSYCHOLOGICAL PERSPECTIVE (1981).

105. Lott, supra note 103, at 51; Major, Gender Differences in Comparisons and Entitlement: Implications for Comparable Worth, 45 J. Soc. ISSUES, No. 4, 1989, at 99, 106; Shepela \& Viviano, Some Psychological Factors Affecting Job Segregation and Wages, in COMPARABLE WORTH AND WAGE DISCRIMINATION: TECHNICAL POSSIBILITIES AND POLTICAL REALTTIES 47, 51-52 (H. Remick ed. 1984) [collection as whole hereinafter COMPARABLE WORTH AND WAGE DISCRIMINATION]; see also Smithson, Introduction: Investigating Gender, Power and Pedagogy, in GENDER IN THE CLASSROOM: POWER AND PEDAGOGY 5 (S. Gabriel \& I. Smithson eds. 1990) (female engineering students rate themselves lower than male colleagues in math, science, and problem-solving despite having higher GPA and SAT scores); Rhode, supra note 53, at 1189 n.139 (1988) (summarizing studies).

106. See J. FERNANDEZ, supra note 99, at 107 (statistics); sources cited in Y. MosES, supra note 99 at 3-6; Bielby, Modern Prejudice and Institutional Barriers to Equal Employment for Minorities, $43 \mathrm{~J}$. Soc. IssuES, No. 1, 1987, at 79; Lawrence, The Id, The Ego, and Equal Protection: Reckoning with Unconscious Racism, 39 STAN. L. REV. 317 (1987); Alexander, Minority Women Feel Racism, Sexism are Blocking the Path to Management, Wall St. J., July 25, 1990, at B1, col. 3.

107. When asked what constituted "too feminine," a typical male manager's response was: "[I]t's hard to explain." A. MORRISON, R. WHITE \& E. VAN VELSOR, supra note 9, at 54, 61-62, 79. For other examples, see Price Waterhouse v. Hopkins, 490 U.S. 228 (1989); A. ASTRACHAN, How MEN FEEL: THEIR RESPONSE TO WOMEN'S DEMANDS FOR EQUALITY AND POWER 151-52 (1986); C. EPSTEIN, supra note 53, at 279-82; B. MILWOOD, WHAT YOU GET WHEN YOU GO FOR IT 140 (1987); UTAH TASK FORCE, supra note 67, at 20. 
but also of "women's work." A growing body of cross-cultural, clinical, and historical evidence indicates that tasks performed by women are undervalued because they are performed by women. ${ }^{108}$ Jobs classified as "female" are thought to require less effort and ability and to deserve less compensation than identical work that is classified as male. ${ }^{109}$ When asked how much pay they deserve for a particular task, women select lower amounts than men. ${ }^{110}$ Such evaluative patterns are apparent across a wide range of cultures. As Margaret Mead once noted, in some villages men fish and women weave, and in other villages women fish and men weave, but in either case the work performed by women is valued less. ${ }^{11}$ Similar biases help account for certain occupational reward structures in this country: school teachers who earn no more than state liquor store clerks and librarians who earn less than crossing guards or watermeter readers. ${ }^{12}$

Such gender biases affect not only the assessment of females' performance, they also affect the performance itself. Negative feedback or special scrutiny leads to increased anxiety, diminished aspirations, and employment difficulties. Initial adverse expectations are reinforced and a self-perpetuating cycle continues. ${ }^{113}$ Women who depart from traditional roles have special visibility, and their performance is often recalled in ways that foster ideologies of denial. Female employees who "don't work out" confirm traditional assumptions about gender-linked capacities and choices, while those who succeed encourage perceptions that gender bias has been eliminated. Since individuals tend to recall patterns that are consistent with prior assumptions and to forget those that are not, these sex-based stereotypes are difficult to dislodge. ${ }^{114}$ The desire to

108. See, e.g., Steinberg \& Haignere, Equitable Compensation: Methodological Criteria for Comparable Worth, in INGREDIENTS, supra note 4, at 157, 165; Reskin, Bringing the Men Back in: Sex Differentiation and the Devaluation of Women's Work, 2 GENDER \& SOC'Y 58, 74-75 (1988), reprinted in THE SOCIAL CONSTRUCTION OF GENDER 145-46 (J. Lorber \& S. Farrell eds. 1991).

109. Wittig \& Lowe, Comparable Worth Theory and Practice, $45 \mathrm{~J}$. Soc. ISSUES, No. 4, 1989, at 1 , 7; see also Major, supra note 105; Major \& Forcey, Social Comparisons and Pay Evaluations: Preferences for Same-Sex and Same-Job Wage Comparisons, 21 J. EXPERIMENTAL SOC. PSYCHOLOGY 393 (1985); McArthur \& Obrant, Sex Biases in Comparable Worth Analysis, 16 J. APPLIED PSYCHOLOGY 757, 766-69 (1986). But see Mount \& Ellis, Sources of Bias in Job Evaluation, 45 J. Soc. IssuEs, No. 4, 1989, at 153, 155-58 (reviewing studies finding no consistent bias in lab settings).

110. A. EAGLY, supra note 102, at 111; Major, supra note 105, at 105; Major \& Forcey, supra note 109, at 393; Major, McFarlin \& Gagnon, Overworked and Underpaid: On the Nature of Gender Differences in Personal Entitlement, 47 J. PERSONALITY \& SOC. PSYCHOLOGY 1399, 1399-1412 (1984).

111. M. MEAD, MALE \& Female: A STUdY OF THE SEXES IN A Changng World 159-60 (1949).

112. See D. KIRP, M. YUDOF \& M. FRANKS, GENDER JUSTICE 168 (1986); Savage, San Jose's Equal Pay Plan Survives, L.A. Times, Sept. 12, 1983, § I, at 3, col. 5.

113. K. DEAUX, THE BEHAVIOR OF WOMEN AND MEN 24-34 (1976).

114. See Aronson, The Theory of Cognitive Dissonance: A Current Perspective, in COGNITIVE THEORIES IN SOCIAL PSYCHOLOGY 181, 192-96 (L. Berkowitz ed. 1978); Hamilton, Stereotyping and Intergroup Behavior: Some Thoughts on the Cognitive Approach, in COGNITIVE PROCESSES IN STEREOTYPING AND INTERGROUP BEHAVIOR 333, 340 (D. Hamilton ed. 1981). See generally L. FESTINGER, A THEORY OF COGNITIVE DISSONANCE (1957). 
believe in a "just world" further reinforces unconscious biases; assumptions about women's incapacity make women's inequality less unfair. ${ }^{115}$

Taken together, these lingering stereotypes reinforce gender hierarchy by obscuring its dynamics. The result is that sex-based subordination appears natural and necessary, rather than a consequence of societal construction and a subject for societal challenge. Dislodging such patterns will require more than the formal equal treatment guarantees that legal doctrine has prescribed. Rather, as subsequent discussion reflects, we need a fundamental reassessment of gender difference and the social disadvantages it has entailed.

\section{The DENIAL OF INEQUALITY}

A second way to dismiss gender inequality as a social problem is to deny that such inequality exists. This strategy takes two forms. Under the first approach, each sex has distinctive attributes, roles, and rewards that are "separate but equal," and definitions of equality are adjusted accordingly. This ideological framework builds on common cognitive processes. As both historical and psychological research make evident, individuals tend to adopt conceptions of fairness that maximize their own entitlement. ${ }^{116}$ Similarly, those in subordinate positions who feel powerless to affect their status often internalize frameworks that deny its injustice. ${ }^{117}$ Thus, for many men, separate-but-equal frameworks can perpetuate advantage by masking its existence. For many women, the illusion of equality has been a comforting substitute for its realization.

The flip side of this strategy has been to devalue rather than celebrate difference. In effect, this approach has confused formal with substantive equality and has ignored the social consequences of sex-linked attributes and experiences. Under this framework, women have been expected to accommodate the demands of formerly male-dominated institutions rather than the converse.

For feminists, these dual strategies have posed longstanding dilemmas. How to acknowledge difference without perpetuating the legal and social disadvantages that have followed from it remains a central challenge.

115. See supra note 12 and accompanying text.

116. Fairness, Preference and Fairness Biases, in EQUTY THEORY: PSYCHOLOGICAL AND SOCIOLOGICAL PERSPECTTVES 61, 82-90 (D. Messick \& K. Cook eds. 1983) [collection as whole hereinafter EQUTTY THEORYl. For examples of in-group bias, see Atkinson, The Perception of Social Categories: Implications for the Social Comparison Process, in 4 RELATIVE DEPRIVATION AND SOCIAL COMPARISON: THE ONTARIO SYMPOSIUM 117, 119-22 (1986) [collection as whole hereinafter RELATIVE DEPRIVATION AND SOCIAL COMPARISON] (individuals randomly assigned to groups but who believe assignment is based on some shared characteristic will favor own group in distributing resources).

117. Major, supra note 105, at 106; Wills, Downward Comparison Principles in Social Psychology, 90 PSYCHOLOGICAL BULL. 245, $264-68$ (1981) (individuals tend to compare themselves with others who are equally or more unfortunate); see also infra text accompanying note 218. 


\section{A. The Embrace of Difference}

In America, separate-but-equal ideologies gained prominence during the early nineteenth century. At a time when industrialization and urbanization in the North were forcing more productive and social activities outside the home, a cult of domesticity emerged to reaffirm the centrality of family life. ${ }^{118}$ Similar patterns occurred in the southern plantation culture, where white femininity embodied pristine virtue and Black femininity was associated with sensuality and base desire. ${ }^{119}$ In both settings, white women acquired an exalted though circumscribed status. Within their separate empire, wives reportedly reigned supreme; from the "throne of the heart," they shaped the character of their children and the destiny of the nation. ${ }^{120}$ To preserve their moral influence, women were to remain free of the "muck and mire" of political and commercial life. ${ }^{121}$ Observers like Alexis de Tocqueville asserted that although women were "confined within the narrow circle of domestic life and their situation [was] one of extreme dependence," nowhere did they occupy a "loftier position." 122

Similar themes emerged throughout the nineteenth and twentieth centuries. Antisuffragists often insisted that unequal rights were not a mark of unequal status, but simply a recognition of sexual difference and complementary roles. Contemporary conservatives have ascribed similar importance to the maternal mission. As Pat Robertson put it: "Who rules our nation? Who is going to determine the next generation? It's not going to be the politicians and the presidents and the senators and the judges - it's going to be the mothers."123

Such views have had significant influence on public policy and private decisionmaking. Issues such as abortion, childcare, welfare, and the Equal Rights Amendment have provided ample legislative opportunity to celebrate difference. They have also mobilized traditional homemakers in defense of their status, dignity, and way of life. In debates over the ERA, many opposition groups chose names that clearly reflected their members' views: "Feminine

118. Welter, The Cult of True Womanhood, 1820-1860, AM. Q., Summer 1966, at 151, 174.

119. See P. GIDDINGS, supra note 26, at 47-52, 53; B. HOOKS, supra note 41 , at 31-39.

120. A. GRAVES, WOMEN IN AMERICA: BEING AN EXAMINATION INTO THE MORAL AND INTELLECTUAL CONDITIONS OF AMERICAN FEMALE SOCIETY 151 (1847).

121. A. KRADITOR, supra note 20, at 18-20 (quoting Florida legislator among others); see also C. DEGLER, supra note 35 .

122. A. DE TOCQUEVILLE, 2 DEMOCRACY IN AMERICA 227 (H. Reeve trans. 4th ed. 1841).

123. The Family and the Law, Address by Pat Robertson, Family Forum II Conference in Washington, D.C. (July 27, 1982), quoted in R. KLATCH, supra note 65, at 136; see also Building a Morally Strong America, Address by J. Denton, Over the Rainbow Celebration in Washington, D.C. (July 1, 1989), quoted in R. KLATCH, supra note 65, at 141 ("Why do women want equality when for four or five thousand years they enjoyed the superiority which we accord them ... ?"). 
AntiFeminists," "Winsome Wives and Homemakers," and "Women Who Want to be Women." 124

\section{Employment}

One of my earliest personal encounters with such separate-but-equal worldviews occurred while I was a Yale law student interviewing for summer jobs. At a leading Wall Street firm, a senior litigator invited me to survey his office crammed with files, folders, and document carriers. He then pointed to a photograph of his wife, four lovely children, and two golden retrievers at leisure on the family's summer estate. Gesturing first toward the picture and then toward the files, he asked with genuine curiosity: "Why would a young lady like you want to trade all this for that?" Why, I wondered, do only ladies have to choose? What I said was rather less memorable.

That same issue reechoes with tedious consistency. Popular press accounts offer endless reruns of the same scripts. In one variation, the unhappy heroine comes fully endowed with meaningful career and miserable life-single and barren, or fertile and frantic. ${ }^{125}$ In an alternative variation, she abandons career for hearth and home, and everyone lives happily ever after. ${ }^{126}$ Such popular morality plays help legitimate gender hierarchy. Their underlying message is that for women, unlike men, family roles require career sacrifice, and anyone who assumes otherwise will pay a substantial price.

A more sophisticated version of this view builds on human capital theories of occupational inequality. According to these theories, women seek to reconcile competing job and family demands by making a lower career investment; they choose occupations that tend not to require extended training, long hours, inflexible schedules, or skills that deteriorate with absence from the

124. For a full catalog of anti-ERA groups, see J. BOLES, supra note 62, at 200-02. Other organizations included: American Women Already Richly Endowed; Happiness of Motherhood Eternal (HOME); Humanitarians Opposed to Degrading Our Girls; Housewives and Motherhood Anti-Lib Movement; Right To Be a Woman; and Women for Maintaining the Differences Between the Sexes and Against the ERA.

125. See, e.g., Amiel, Feminism Hits Middle Age, NAT'L REv., Nov. 27, 1989, at 24 (noting that many women in suits bought with their own credit cards find "no one to come home to"); Salholz, Michael, Staff, Doherty, Abramson \& Winger, Too Late for Prince Charming?, NEWSWEEK, June 2, 1986, at 54-55.

126. See, e.g., Finkel, The Last Housewife in America, ESQUIRE, July 1990, at 102; Fisher, I Want to Stay Home-Where I Belong, REDBOOK, Apr. 1986, at 96; Larson, I Was a Career Junkie, WORKING WoMAN, June 1986, at 48; Mansfield, Hittin' It Big \& Kissin' It Goodbye, Wash. Post, Feb. 26, 1985, at C1, col. 3. See generally Evans, Mothers Making Themselves More at Home, Wash. Post, Oct. 2, 1989, at Al, col. 1 . 
workforce. ${ }^{127}$ From this vantage, sex-based disparities in employment status are a justifiable reflection of sex-based choices regarding family roles.

Although such accounts have some factual basis, they exaggerate the gender difference on which their conclusion depends. It is true that women are more likely to take extended leaves, work part-time, and place somewhat lower priority on occupational advancement than their male counterparts. ${ }^{128}$ But a growing body of research suggests that these characteristics may be more a response to, than a cause of, employment segregation and stratification..$^{129}$ So too, most studies find that human capital factors such as experience, education, hours worked and so forth cannot account for more than half of all gender disparities. ${ }^{130}$ On the whole, women who make comparable investments in time, training, and experience do not advance as far or as fast as their male counterparts. ${ }^{131}$ Nor does their work command comparable rewards. Human capital theories cannot explain the patterns of undervaluation noted earlier, in which tasks performed by women are rated lower than identical work performed by men. ${ }^{132}$ To account for these dynamics requires acknowledgement of gender biases that separate-but-equal frameworks deny.

So too, the gender roles that these frameworks prescribe are increasingly out of step with the needs and aspirations of most women. By choice or

127. G. BECKER, HUMAN CAPITAL 178-80 (2d ed. 1975); M. LEVIN, supra note 71, at 145-51; J. ROBACH, A MATTER OF CHOICE 30-32 (1986); Blau \& Jusenius, Economists' Approaches to Sex Segregation in the Labor Market: An Appraisal, in WOMEN AND THE WORKPLACE: THE IMPLICATIONS OF OCCUPATIONAL SEGREGATION 181, 185-88 (M. Blaxall \& B. Reagan eds. 1976) [collection as whole hereinafter WOMEN AND THE WORKPLACE]; Finn, The Earnings Gap and Economic Choices, in EQUAL PAY FOR UNEQUAL WORK 100, 105-14 (P. Schlafly ed. 1984); Levin, The Earnings Gap and Family Choices, in EQUAL PAY FOR UNEQUAL WORK, supra at 125, 130-35. See generally Becker, Human Capital: Effort and the Sexual Division of Labor, 3 J. LAB. ECON. 533 (1985).

128. Research on women's differential expectations of success is summarized in D. KAUFMAN \& B. RICHARDSON, ACHIEVEMENT AND WOMEN: CHALLENGING THE ASSUMPTIONS 49-50, 96 (1982); Lacey, Job Attribute Preference and Work Commitment of Men and Women in the U.S., 36 PERSONNEL PSYCHOLOGY 324 (Summer 1983).

129. R. KANTER, MEN AND WOMEN OF THE CORPORATION 149-59 (1977); Schultz, Telling Stories About Women and Work: Judicial Interpretations of Sex Segregation in the Workplace in Title VII Cases Raising the Lack of Interest Argument, 103 HARV. L. REV. 1749, 1819, 1828-29 (1990).

130. See H. AARON \& C. LOUgY, THE COMPARABLE WORTH CONTROVERSY 12-13 (1986); Hartmann, Roos \& Trieman, An Agenda for Basic Research on Comparable Worth, in COMPARABLE WORTH: NEW DIRECTIONS FOR RESEARCH 13-33 (H. Hartmann ed. 1985).

131. See, e.g., ABA COMM'N ON WOMEN IN THE PROFESSIONS, REPORT TO THE HOUSE OF DELEGATES 2-6 (1988) [hereinafter ABA COMM'N ON WOMEN]; Spurr, Sex Discrimination in the Legal Profession: A Study of Promotion, 43 INDUS. \& LAB. REL. REV. 406 (1990) (women about half as likely as men to achieve partnership during surveyed years even though they did not differ significantly from men in academic distinction or productivity); Strober, The MBA Degree: Same Passport to Success for Women and Men?, in WOMEN IN THE WORKPLACE 24, 39-42 (P. Wallace ed. 1982) (finding that female MBA's advance less far than similarly qualified males).

For a critical review of human capital theories and their inability to account for various wage and occupational patterns, see Blau, Occupational Segregation and Labor Market Discrimination, in SEX SEGREGATION IN THE WORKPLACE 118-26 (B. Reskin ed. 1984); Corcoran \& Duncan, Work History, Labor Force Attachment, and Earnings Differences Between the Races and Sexes, 14 J. HUM. RESOURCES 3 (1979); England, The Failure of Human Capital Theory to Explain Occupational Sex Segregation, 17 J. HUM. RESOURCES 358 (1982).

132. See supra text accompanying notes 103-05, 108-12. 
necessity, a growing percentage of women have become single heads of households, a trend especially pronounced among women of color. ${ }^{133}$ Recent research generally indicates that women who combine work and family roles have the highest rates of satisfaction and that increasing percentages of wives prefer their husbands assume equal domestic responsibilities. ${ }^{134}$ Of course, as subsequent discussion suggests, these preferences remain a substantial distance from realization. ${ }^{135}$ But it is nonetheless significant that a growing majority of women aspire to equality on different terms than those separate-butequal frameworks envision.

\section{Associations}

Such frameworks present comparable problems in other contexts, particularly those where celebration of women's difference occurs in their absence. Single-sex associations are an obvious illustration. To many observers, such gender segregation is not a form of gender discrimination but an affirmation of gender differences. ${ }^{136}$ From this vantage, it is sufficient that women have their own organizations; if members of elite male clubs want a private space protected from female intrusion, feminists should not make a federal case out of it. ${ }^{137}$

On that point, the judiciary has agreed. It has distinguished public and private institutions and exempted the latter from federal equal protection doctrine. ${ }^{138}$ Such distinctions ignore the extent to which private associations receive public support and serve public functions. All-male clubs typically depend on tax subsidies and liquor licenses, while providing opportunities for professional contacts and career networks that all-female clubs cannot duplicate. ${ }^{139}$ In recognition of that fact, a growing number of states and localities

133. McAdoo, supra note 7, at 71-74; Wilson \& Neckerman, Poverty and Family Structure, in FIGGTING POVERTY: WHAT WORKS AND WHAT DOESN'T 232 (S. Danziger \& D. Weinberg eds. 1986).

134. DeStefano \& Colasanto, supra note 79, at BS, col. 5; see also J. PLECK, supra note 80 , at 90-92; 1985 VIRGINIA SLIMS POLL, supra note 79 (56\% of women preferred a marriage in which both shared equally).

135. See infra text accompanying notes 202-10.

136. For example, according to Robert Strub of Los Angeles' California Club, the organization has "no restrictions on any members except that it's a men's club. I don't consider that discrimination." As quoted in Burns, The Exclusion of Women from Influential Clubs: The Inner Sanctum and the Myth of Full Equality, 18 HARV. C.R.-C.L. L. REV. 321, 324 n.6 (1983); see also Reuben, Free Association Rights Said Unclear After Rotary Ruling, L.A. Daily J., May 26, 1987, at 1, col. 2. col. 1 .

137. Fairlie, Clothes, Clubs and the Trivialization of Civil Rights, Wash. Post, Nov. 23, 1980, at C2,

138. See Moose Lodge No. 107 v. Irvis, 407 U.S. 163 (1972); Rhode, Association and Assimilation, 81 NW. U.L. REV. 106, 114-15 (1986).

139. Roberts v. United States Jaycees, 468 U.S. 609, 625 (1984). See generally sources cited in Burns, supra note 136; Rhode, supra note 138. 
have passed legislation banning sex discrimination by clubs over a certain size that host business activities. ${ }^{140}$

Yet contrary to popular perceptions, we haven't solved the problem; we have only moved it to a new level. Changes in formal policy do not guarantee changes in social practice. Getting some women in the door does not get most women to the right tables or to the less institutionalized networks of support, guidance, and collegial contacts. Women's stories of exclusion and marginalization reveal striking similarities across a wide variety of cultural contexts. ${ }^{141}$ Such subordination is compounded by ideologies of denial that deny its existence and reinforce its dynamics.

As in other contexts, separate but equal is a contradiction in terms. Assumptions that make segregation seem necessary make equality impossible. ${ }^{142}$ Men's and women's affiliations cannot be equated. Separatism imposed by dominant groups carries different symbolic meanings and social consequences than separatism chosen by subordinate groups. Given this nation's historic traditions and power disparities, the exclusion of men from women's associations neither conveys inferiority nor perpetuates subordination. By contrast, male separatism reinforces male advantage. A wide array of social science research indicates that individuals who seem different are often disliked or avoided in work-related contexts. ${ }^{143}$ Women who don't "fit in" at clubhouse lunches won't fare much better in other business contexts.

So too, the explanations male club members privately advance for sex-based exclusions cast doubt on the egalitarian rhetoric they publicly proclaim. Female members reportedly would alter club decor and decorum. If a man has a deal to discuss he "wouldn't want to sit next to a woman fussing about how much mayonnaise is in her chicken salad." 144 Such stereotypes are self-perpetuating. As long as no women are present, it is impossible to counteract the assumption that men concentrate on mergers and women on mayonnaise.

Yet as with other feminist struggles, the danger is that the problem will be too narrowly conceived. A preoccupation with formal access for women deflects

140. Club Doors Are Open, but Women Draw Back, N.Y. Times, Sept. 14, 1988, at C1, col. 4; see also Burns, supra note 136, at 395 (discussing legal initiatives).

141. See, e.g., ABA COMM'N ON WOMEN, supra note 131, at 9-11; A. MIRANDE \& E. ENRIQUEZ, supra note 26, at 133-35; J. FERNANDEZ, supra note 99, at 88-94; Y. MOSES, supra note 99, at 18; M. WALSHOK, BLUE COLLAR WOMEN: PIONEERS ON THE MALE FRONTIER 158, 168-70, 186-204 (1981); Burleigh, Black Women Lawyers: Coping with Dual Discrimination, A.B.A. J., June 1, 1988, at 64; Deaux, Blue Collar Barriers, 27 AM. BEHAVIORAL SCIENTIST 287, 288 (1984); Epstein, Workplace Boundaries: Conceptions and Creations, 56 Soc. REs. 571, 579-90 (1989); sources cited in Rhode, Occupational Inequality, 1988 DUKE L.J. 1207, 1221-22.

142. A. DWORKIN, supra note 62 , at 202.

143. Pettigrew \& Martin, Shaping the Organization Context for Black American Inclusion, $43 \mathrm{~J}$. SoC. ISSUES, No. 1, 1987, at 41, 58; Wilder \& Allen, Effects of Social Categorization and Belief Similarity upon Intergroup Behavior, 1 PERSONALITY \& SOC. PSYCHOLOGY BULL. 281-83 (1974); see also Lipman-Blumen, Toward a Homosocial Theory of Sex Roles: An Explanation of the Sex Segregation of Social Institutions, in WOMEN AND THE WORKPLACE, supra note 127, at 15-16.

144. Trillin, Tampa, Florida: Four People Who Do Not Lunch at the University Club, NEW YORKER, Apr. 11, 1977, at 101 . 
attention from the class and racial barriers that constrain it. In attempting to become "full members of the club," many individuals may lose the perspective needed to challenge its underlying premises. Once inside, women have less incentive to question the closed network of privilege that membership reflects and reinforces.

If feminism is to express the underlying values that gave it birth, the struggle cannot end with women's access to men's institutions. As examples like Margaret Thatcher remind us, getting a woman into power is not the same as empowering women. The challenge for contemporary feminists is to enable women to ascend the hierarchy without losing their commitment to change it.

\section{Athletics}

Similar challenges arise in other contexts in which separate-but-equal ideologies persist. Women's athletics offers a final case in point. Historically, there has been little pretense about the equal. Assumptions about sexual difference and social roles made women seem unsuitable for sports and sports unsuitable for women. ${ }^{145}$ Social conventions initially limited female athletes to activities that did not give rise to indelicate sweat or unfeminine rivalry. ${ }^{146}$ As women's physical education programs developed, their leaders argued for models different from, but equal to men's-for goals less commercial and competitive and more concerned with wide participation and positive social interaction..$^{147}$

In practice, those models succeeded more in establishing difference than equality. By the late 1960 's and the early 1970's, their limitations were widely apparent. No athletic scholarships were available to women, interscholastic programs were relatively rare, and many physical education programs stressed activities that required few skills or resources (ringtossing and rhythmic hulahooping) or that promoted vicarious roles (cheerleading and pep clubs). ${ }^{148}$

145. For assumptions that females were unfit for, or would be unsexed by, sports, see H. LENSKYJ, OUT OF BOUNDS: WOMEN, SPORTS AND SEXUALITY 23, 100 (1986); K. MCCRONE, SPORT AND THE PHYSICAL EMANCIPATION OF ENGLISH WOMAN 84, 135, 278-79 (1988) (describing concerns); Hargreaves, Victorian Familism and the Formative Years of Female Sport, in FROM "FAIR SEX" TO FEMINISM 130 (J. Mangan \& R. Park eds. 1987).

146. See, e.g., P. BERLIN, J. FELSHIN, E. GERBER \& W. WYRICK, THE AMERICAN WOMAN IN SPORT 4-10 (1974); U.S. COMM'N ON CIVIL RIGHTS, MORE HURDLES TO CLEAR 1-3 (1980); Spears, The Emergence of Women in Sport, in WOMEN's ATHLETICs 9 (B. Hopner ed. 1974).

147. H. LENSKYJ, supra note 145, at 100; Chandler, The Association for Intercollegiate Athletics for Women: The End of Amateurism in United States Intercollegiate Sports, in WOMEN IN SPORT: SOCIOLOGICAL AND HISTORICAL PERSPECTIVES 5, 7-9 (1985); see also Birrell, The Woman Athlete's College Experience: Knowns and Unknowns, 11 J. SPORT \& SOC. IsSUES 82, 82-83 (1987).

148. See M. BOUTILIER \& L. SAN GIOVANNI, THE SPORTING WOMAN 32-42 (1983); U.S. CoMM'N ON CIVIL RIGHTS, supra note 146, at 1-2; Farrell, Many Women Link Anti-Sex Bias Law to Outstanding Olympic Performances, Chron. Higher Educ., Aug. 29, 1984, at 31; sources cited infra note 156. 
Surveys of expenditures for boys' and girls' athletics found ratios ranging from $8: 1$ to $450: 1 . .^{149}$

Passage of Title IX of the Civil Rights Act in 1972 brought limited progress. The Act prohibited sex discrimination in educational programs receiving federal funds, but its application to athletics was somewhat murky. ${ }^{150}$ Congressional sponsors made plain that they did not expect intercollegiate football to be "desegregated." 151 What they were expecting remained less clear. Subsequent regulations required that institutions provide "equivalent opportunity" to "accommodate the interests and abilities of members of both sexes" but left considerable room for argument about what constituted "equivalent." 152

At institutions like Yale, administrators commonly assumed that sex-based differences justified sex-based disparities, and displayed little interest in "accommodating" female athletic abilities if it required diverting resources from males. The consequence was a series of awkward turf battles, literally as well as figuratively. The Yale women's field hockey team was less than enthusiastic about its initial playing space in Parking Lot A, which often hosted cars and debris as well as athletes. ${ }^{153}$ The women's varsity tennis and crew teams received space for practice but no nearby lavatory facilities. Polite protests brought jovial reminders that members should be improving their skills not powdering their noses. Underlying that banter was the latent assumption that female athletes ought not to expect "equal reward for unequal talent." 154 To get shower facilities at their boathouse, the women's crew team finally resorted to a "Title IX strip." In preparation for a meeting with the Director of Athletics, they printed Title IX in block letters on their bare backs. At a suitable moment they disrobed before invited guests, including a photographer for The New York Times. A picture ran the following day; the following year the boathouse had women's showers. ${ }^{155}$

Although such discreet protests have resulted in substantial improvements, equally substantial gender disparities remain. National surveys have revealed continued discrimination in coaching, facilities, equipment, practice options,

149. D. TYACK \& E. HANSOT, supra note 93, at 263; Warren, Justice and Gender in School Sports, in WOMEN, PHILOSOPHY AND SPORT: A COLLECTION OF NEW ESSAYS 12 (B. Postow ed. 1983) [collection as whole hereinafter WOMEN, PHILOSOPHY AND SPORT] (noting that it was not uncommon for coeducational high schools and colleges to spend less than one percent of their athletic budgets on sports for women).

150. 20 U.S.C. $\S 1681$ (1988).

151. 117 CONG. REC. 30,407 (1971) (statement of Sen. Birch Bayh).

152. See 45 C.F.R. $\$ 86.41$ (b)-(c). See generally M. BOUTILIER \& L. SAN GIOVANNI, supra note 148, at 171-72 (discussing inadequacies of Title IX); Birrell, supra note 147, at 83-86; Tokarz, Separate but Unequal Educational Sports Programs: The Need for a New Theory of Equality, 1 BERKELEY WOMEN's L.J. 201, 211-17 (1985). 1.

153. Warren, Women Athletes Tell of Fights for Respect, Yale Daily News, Nov. 30, 1989, at 3, col.

154. Levin, supra note 127 , at 217.

155. Warren, supra note 153. 
competitive schedules, and related areas. ${ }^{156}$ Women of color confront further obstacles in obtaining adequate resources and encouragement. ${ }^{157}$ Moreover, as feminists have long argued, the objective is not only to equalize athletic opportunities, but also to transform them. Again, the principal problem is that the problem may be too narrowly defined. Women are being asked to settle for some pared-down version of models that men have established. Developing alternatives that are more participatory and less exploitive presents a continuing challenge. ${ }^{158}$ The problem, thus reformulated, is how to gain equality without relinquishing difference.

\section{B. The Devaluation of Difference}

An alternative way to understate gender inequality is to undervalue gender difference. This approach defines equality in formal rather than substantive terms and assumes that equal access is a sufficient guarantee of equal acceptance. Adherents of this position typically point to recent changes in gender roles and formal rights and conclude, as did Britain's Lord Denning, that "women's equality is complete." 159

Ironically enough, women have long been excluded from employment, educational, and political settings on the ground that they are different; once admitted, the assumption has often been that they are the same. Female entrants are expected to accommodate existing institutional norms; those norms are not expected to change to accommodate women. The dominant view is similar to that of Harvard Law School Dean Erwin Griswold when female students first gained admission to the Law School in 1950. To Griswold, this development did not seem "very important or very significant. Most of us have seen women from time to time in our lives, and have managed to survive the shock.... I think we can take it, and I doubt it will change the character of the School or even its atmosphere to any detectable extent." 160

156. Birrell, supra note 147, at 86-91; Olson, Beyond Tïle IX: Toward an Agenda for Women and Sport in the 1990s, 3 YALE J.L. \& FEMINISM 105, $117-19$ (1990); Tokarz, supra note 152, at 230; Diesenhouse, More Women Playing, but Fewer Are Calling the Shots, N.Y. Times, Dec. 11, 1990, at D25, col. 4.

157. See BLACK WOMEN IN SPORTS 5, 9-10 (T. Green, et al. eds. 1981); M. BOUTILIER \& L. SAN GIOVANNI, supra note 148, at 18, 175; WOMEN's SPORTS FOUNDATION, THE WOMEN'S SPORTS FOUNDATION REPORT: MNORITIES IN SPORTS (1989); Dunkle, Minority and Low-Income Girls and Young Women in Athletics, 12 EQUAL PLAY (1985).

158. M. BOUTILIER \& L. SAN GIOVANNI, supra note 148, at 247-48; C. MACKInNoN, Women, SelfPossession, and Sport, in FEMINISM UNMODIFIED 117, 117-24 (1987); Addelson, Equality and Competition: Can Sports Make a Woman of a Girl?, in WOMEN, PHILOSOPHY AND SPORT, supra note 149, at 133, 149-55; Lemaire, Women and Athletics: Toward a Physicality Perspective, 5 HARV. WOMEN's L.J. 121, 131-42 (1982); Olson, supra note 156, at 117-19.

159. As quoted in C. SMART, FEMINISM AND THE POWER OF LAW 12 (1989) (discussing women's property rights).

160. Griswold, Developments at the Law School, 1950 HARV. L. SCH. Y.B. 10. 


\section{Occupational Inequality}

Such devaluations of difference help explain women's difficulties in employment contexts that have been structured primarily by and for men. Despite a quarter-century's experience with equal opportunity legislation, women's experience remains far from equal. Female workers have moved into maledominated professions but, as noted earlier, they are still dramatically underrepresented at the highest levels of occupational status and financial reward. For example, they hold about $13 \%$ of tenured academic posts, $6 \%$ of the partnerships of large law firms, $5 \%$ of federal elective offices, and $3 \%$ of executive positions at publicly traded corporations. ${ }^{161}$ Female underrepresentation in the highest paying skilled trade positions is similar, and all of these disparities are greater for women of color. ${ }^{162}$ The vast majority of American employees remain within occupations or job classifications that are gender segregated and gender stratified. ${ }^{163}$ As a consequence, equal pay mandates have not brought men and women significantly closer to obtaining equal pay. Full-time female workers earn about $65 \%$ of the annual salary of full-time male workers, the same as in 1955, and women of color again remain at the bottom of the economic hierarchy. ${ }^{164}$ Gender-based pay disparities persist within job categories even among workers with comparable credentials. ${ }^{165}$

161. Impellizzeri, Women, Minorities Made Gains at City Firms, MaNhatTAN LAW., Mar. 1990, at 4 (15\% of new partners are women although women's enrollment at law schools has climbed from $20 \%$ in 1975 to $41 \%$ in 1989); see also A. MORRISON, R. WHITE \& E. VAN VELSOR, supra note 9, at 5-6; G. POWEL, supra note 102, at 78-79.

162. For barriers in blue collar work, see Hearings on Women in Nontraditional Jobs Before the Subcomm. on Civil and Constitutional Rights of the House Judiciary Comm., 100th Cong., 1st Sess. 73 (1987); Women in the Work Force: Supreme Court lssues: Hearings Before the Subcomm. on Employment Opportunities of the House Comm. on Education \& Labor, 99th Cong., 2d Sess. 44 (1986) (statement of Cynthia Marano); Law, "Girls Can't Be Plumbers"-Affirmative Action for Women in Construction: Beyond Goals and Quotas, 24 HARV. C.R.-C.L. L. REV. 45 (1989); Schultz, supra note 129, at 1827-32. For statistics concerning women of color, see THE AMERICAN WOMAN, supra note 7, at 381-86, 394-97; G. POWELL, supra note 102, at 78-79; Malveaux, Gender Difference and Beyond: An Economic Perspective on Diversity and Commonality Among Women, in THEORETICAL PERSPECTIVES, supra note 38, at 226; Silver, Few Women Minorities at the Top, Wash. Post, Aug. 14, 1990, at A1, col. 1 (women constitute only 3\% of senior executives and racial minorities less than $1 \%$, and little change has occurred between 1979 and 1989); Harlan, Women Still Earn Less than Men as Lawyers, Wall St. J., Apr. 21, 1989, at B1, col. 1.; supra note 4.

163. S. BIANCHI \& D. SPAIN, AMERICAN WOMEN IN TRANSITION 180-88 (1986); B. RESKIN \& P. ROOS, JOB QUEUES, GENDER QUEUES: EXPLAINING WOMEN'S INROADS INTO MALE OCCUPATIONS (1990); Bielby \& Baron, Undoing Discrimination: Job Integration and Comparable Worth, in INGREDIENTS, supra note 4, at 228; Hartmann, Roos \& Treiman, supra note 130, at 3-4.

164. See Kleiman, Glass Ceilings for Black Women, San Francisco Examiner, Nov. 26, 1990, at B1, col. 1, B5 (discussing survey findings of double jeopardy for Black women and noting that they make up only $1 \%$ of all lawyers and $2 \%$ of all managers); sources cited supra notes 4 \& 7 .

165. Thorner, supra note 99, at 94-95 (citing studies of pay disparities among women lawyers); Roman, Women Beware: An MBA Doesn't Mean Equal Pay, BUS. WK., Oct. 29, 1990, at 57 (12\% pay disparity between men and women MBA graduates; substantial differences persist even when graduates are grouped by industry); supra note 131 . 
As was true a century earlier, the central problem is that too many individuals deny that any serious problem exists. Although recent surveys find increasing perceptions of gender bias, a large percentage of the public still doubts its significance. Between 40 and $50 \%$ of surveyed men do not believe that women experience discrimination for top positions in government, business, or the professions. ${ }^{166}$ Among lawyers, almost four-fifths of women but less than half of men believe that there is gender bias in the bar. ${ }^{167}$

To many decisionmakers, gender inequalities in employment appear primarily due to cultural lag or employee choice, and are not a matter for policy initiatives. This perspective reflects a "now-you-see-them-now-you-don' $t$ " view of women workers. For positions carrying the greatest social status and economic rewards, female candidates are always in the pipeline but rarely in the pool from which final selections are made. Adherents to this view are always cheerful about its implications: gender roles are breaking down, women are moving up, and full equality is just around the corner. At the moment, however, for the positions at issue, women, especially women of color, are reportedly unqualified or unavailable. ${ }^{168}$

Feminists who have listened to such upbeat but unchanging predictions over extended periods tend to be rather less optimistic. At prevailing rates of change, it could take between seventy-five and one hundred years to achieve a sexually

166. 1985 VIRGINIA SLIMS POLL, supra note 79 , at 11 (male sample: $48 \%$ government, $44 \%$ profession, $41 \%$ government positions).

167. ABA COMM'N ON WOMEN, supra note 131, at 2; see also Schafran, The Obligation to Intervene: New Direction from the American Bar Association Code of Judicial Conduct, 4 GEO. J. LEGAL ETHICs 53, 69 (1990) (noting low percentage of male judges who perceived gender bias compared with other observers); Wickler, Judicial Education: An Overview, in 1989 PROC. NAT'L CONF. ON GENDER BIAS IN CTS. 53 (reporting consensus among participants in initial judicial education sessions that "gender had never affected interactions in their courtrooms or chambers in any way whatsoever"); infra note 284 and accompanying text.

168. For example, on Wall Street, although it took some firms 140 years to hire their first women and the top ranking partners are still $99 \%$ male, a representative view is that "[ $t$ ] he big investment banks have been a little slow off the mark ... [b]ut women are beginning to come into their own now, and you'll see many more reaching the top in the next few years." A. FISHER, WALL STREET WOMEN 7 (1990). In accounting, where women constitute $5.6 \%$ of the partners at the largest firms, the perception among many male decisionmakers is that the problem will naturally correct itself as many more women are "pushing their way up the pipeline." Berg, The Big Eight: Still a Male Bastion, N.Y. Times, July 12, 1988, at D7, col. 1 (quoting Shaun O'Malley, chairman of Price Waterhouse); Kristof, Women at Top-Almost, L.A. Times, May 28, 1990, at D1, col. 2 (survey of highest paid executives at publicly held California firms disclosed fewer than 50 women out of 2300 ; a representative response was: "We are getting the problem straightened out at the bottom . . . but it will take some time before those women find their ways to the top.").

This ideology of denial is reinforced by individuals' tendencies to overgeneralize from particularly memorable and therefore cognitively "available" occurrences. Women who depart from traditional roles have special visibility; those who don't work out confirm traditional assumptions while those who succeed encourage perceptions that bias has been eliminated. For discussion of the availability bias, see Markus \& Zajonc, The Cognitive Perspective in Social Psychology, in 1 HANDBOOK SOC. PSYCHOLOGY 137, 181-82 (3d ed. 1985); Nisbett, Borgida, Crandall \& Reed, Popular Induction: Information Is Not Necessarily Informative, in COGNITION AND SOCIAL BEHAVIOR 113, 128-29 (J. Carroll \& J. Payne eds. 1976); Tversky \& Kahneman, Availability: A Heuristic for Judging Frequency and Probability, 5 COGNITIVE PSYCHOLOGY 207 (1973). 
balanced workforce. ${ }^{169}$ Moreover, as noted earlier, surveys of men and women with comparable career investments find that women do not advance as far or as fast. ${ }^{170}$ Something is happening between the pipeline and the pool that requires further explanation.

When confronted with such disparities, many individuals' second line of defense is a variation of the human capital model. If women have failed to obtain certain positions, it has been because they are not making the necessary sacrifices. Yet unlike disciples of separate but equal, these observers see nothing natural or appropriate about women's different choices. Rather, the assumption is that female employees should, and increasingly will, find ways to succeed within current workplace structures.

Once again, my most direct encounter with such devaluations of gender difference began in law school with summer job interviews. From a prominent Chicago litigator I learned that there was no "woman problem" at his firm. One of his sixty-odd partners was female, and she had no difficulties reconciling her personal and professional obligations. Why just last year she had given birth to her first child on a Friday and was back in the office the following Monday.

As increasing numbers of women have entered the professions, the novelty of such accounts is wearing thin. Stories of women returning from maternity leave faster than a speeding bullet are commonplace. ${ }^{171}$ At this point, the record for reconciling productive and reproductive rhythms may have been set by an attorney who drafted interrogatories during labor while timing her contractions. If you're billing at six-minute intervals, why waste a moment? For the "woman on the road to success," no detours from the standard workplace obligations are advisable. According to one representative account, you should never "make an issue out of being female," or "shirk late hours or weekend projects." 172 Nor should you cook and tell; if you must go home to prepare dinner you should avoid having "anyone know about it." Never should you present yourself as "anything but a hard-driving capable lawyer."173 Above all, that author concludes, "Be yourself." 174

169. 2 U.S. COMM'N ON CIVIL RIGHTS, COMPARABLE WORTH: ISSUE FOR THE 80's, at 109 (1984) (statement of Joy Ann Grune).

170. See supra notes $130-31$ and accompanying text.

171. See, e.g., Brill, Labor Pains, AM. LAW., Jan.-Feb. 1986, at 1, 13-14 [hereinafter Brill, Labor Pains]; Brill, The Woman Problem, AM. LAW., Feb. 1983, at 9; Bruck, The Impeccable Carla Hills, AM. LAW., Apr. 1983, at 84-87; see also B. STAUKTBERG, PREGNANCY NINE TO FIVE: THE CAREER WOMAN's GUIDE TO PREGNANCY AND MOTHERHOOD 133-34 (1985) (describing triumphs of executive bedridden due to pregnancy complications who managed to continue her job attired in tailored blue suit from her rented hospital bed); Martin, Deconstructing Organizational Taboos: The Suppression of Gender Conflict in Organizations, 1 ORGANIZATION SCI. 339 (1990) (describing executive who arranged her caesarean to permit participation through closed circuit television in launching major product line from her hospital bed).

172. A. FISHER, supra note 168, at 71; Strachan, A Map for Women on the Road to Success, 70 A.B.A. J. 94, 94-96 (1984).

173. Strachan, supra note 172 , at 95 .

174. Id. 
For the woman whose self is uncomfortable with such advice, the alternative is exclusion from leadership positions or relegation to a separate lower status "mommy track." 175 The dominant assumption is that effective professional performance requires "total commitment," which is incompatible with part-time work, flexible schedules, and extended caretaking leaves. ${ }^{176}$ Accommodation of women's different family responsibilities appears to create problems of coordination, duplication, overhead, and envy, and their price is often taken as prohibitive. ${ }^{177}$ Resentment against "special treatment" remains common, and what constitutes "special" is generally determined from a male reference point. To many executives, business is "tough enough without having to deal with a woman's life style." 178 Female representation among upper level managers does not necessarily improve the situation if it remains at token levels. Women whose success has depended on internalizing dominant norms often believe that if "I managed without parental leave, so can you." 179

In the face of such assumptions, law has generally kept safely out of view. Neither courts nor legislators have been willing to provide affirmative protection for childbirth, despite the obvious gender inequalities that result. Indeed in its initial analysis of the issue, the Supreme Court reached the novel conclusion that discrimination against pregnancy did not constitute discrimination against women. According to a majority of Justices, medical insurance policies that excluded childbirth did not even involve "gender as such"; employers were simply drawing a distinction between, in the Court's now memorable phrase, "pregnant women and nonpregnant persons." ${ }^{180}$ Although legislative initiatives have reversed that decision, they have left its basic premises unchallenged. The nation's failure to ensure adequate caretaking leaves, flexible schedules, and affordable childcare prevents an integration of workers' productive and repro-

175. Kingson, Women in the Law Say Path ls Limited by “Mommy Track," N.Y. Times, Aug. 8, 1988, at 1 , col. 5. Felice Schwartz has advocated separate, slower professional tracks for those women who wish to accommodate family responsibilities. Schwartz, Management Women and the New Facts of Life, HARV. BUS. REV., Jan.-Feb. 1989, at 67.

176. Beyette, Day-Care Dilemma, L.A. Times, Nov, 1, 1989, at E1, col. 3; see also sources cited infra notes 177-79.

177. On barriers to part-time work, see Brill, Labor Pains, supra note 171, at 13; Project, Law Firms and Lawyers with Children: An Empirical Analysis of Family/Work Conflict, 34 STAN. L. REV, 1263, 127577, 1297 (1982); Rhode, supra note 53, at 1185-86; Rodgers \& Rodgers, Business and the Facts of Family Life, HARV. BUS. REV., Nov.-Dec. 1989, at 121, 127.

178. See also A. FISHER, supra note 168, at 13 (quoting objections such as, "What is this maternityleave crap? I never had maternity leave."); Hughes, Pregnant Professionals Face Pressures at Work as Attitudes Toward Them Shift, Wall St. J., Feb. 2, 1991, at B6, col. 5 (describing law firm partners' attitude of "[w]e don't spend time with our families; why should you?").

179. Gardner, Bonding Time for the Family, Christian Sci. Monitor, June 22, 1990, at 13, col. 2 (quoting woman manager).

180. General Elec. Co. v. Gilbert, 429 U.S. 125, 134 (1976), quoting Geduldig v. Aiello, 417 U.S. 484, 489 n.20 (1974). 
ductive lives. ${ }^{181}$ As long as women assume a disproportionate share of family responsibilities, they will bear a disproportionate cost of those policy failures.

The result is a self-perpetuating cycle of devaluation in which equality in formal rights masks inequality in daily experience. Many women with substantial caretaking obligations have little choice but to drop out of the most demanding positions. Those who remain are likely to be single, childless, or willing to minimize family roles. ${ }^{182}$ Under this Darwinian selection system, the individuals with greatest influence on workplace structure are those with the least personal understanding of its inadequacies.

\section{EEOC v. Sears as a Case Study}

The limits of current legal doctrine, and the dilemma they present for contemporary feminists, are apparent in the growing number of discrimination cases in which employers ascribe women's underrepresentation to women's differences. ${ }^{183}$ The most celebrated of these cases involved an Equal Employment Opportunity Commission complaint against Sears, Roebuck and Company charging that Sears had discriminated against women in high-paying commission sales positions. Although EEOC statistics reflected substantial underrepresentation of women in such positions, the federal district court accepted Sears' claim that such patterns were attributable to women's own preferences, including women's reluctance to work irregular hours and their discomfort with unfamiliar products and competitive compensation structures. ${ }^{184}$

The case gained particular attention on several counts. Sears is the nation's largest private-sector employer of women, and sales work, which is highly gender segregated, is the occupation with the single highest gap in pay between the sexes. ${ }^{185}$ Moreover, the defendant relied on a prominent feminist scholar, Rosalind Rosenberg, for support of its claim that women's differences explained women's underrepresentation. Rosenberg testified that female employees often have elevated traditional values of care and noncompetitiveness over opportunities for economic gain. The EEOC countered this claim with substantial rebuttal evidence, including testimony by another equally prominent feminist historian,

181. See generally Dowd, Work and Family: Restructuring the Workplace, 32 ARIZ. L. REV. 431 (1990); Dowd, Work and Family: The Gender Paradox and the Limitations of Discrimination Analyses in Restructuring the Workplace, 24 HARV. C.R.-C.L. L. REV. 79 (1989); Rodgers \& Rodgers, supra note 177; Taub, From Parental Leaves to Nurturing Leaves, 13 N.Y.U. REV. L. \& SOC. CHANGE 381 (1984-85); sources cited infra note 235.

182. See D. RHODE, supra note 3, at 175; sources cited supra notes 171 \& 177; cf. Abrams, Gender Discrimination and the Transformation of Work-place Norms, 42 VAND. L. REV. 1183, 1239 (1989) (noting absence of women among policymakers).

183. Schultz, stpra note 129, at 1766-77 (courts in almost half of 54 reported cases between 1972 and 1989 considering issue of sex segregation attributed it to women's work preferences).

184. EEOC v. Sears, Roebuck \& Co., 628 F. Supp. 1264, 1308-15 (N.D. Ill. 1986).

185. Milkman, Women's History and the Sears Case, 12 FEMINIST STUD. 375 (1986). 
Alice Kessler-Harris, concerning women's interest in nontraditional employment alternatives. Kessler-Harris' testimony stressed the variability in jobs and schedules that women have historically accepted, the ability of economic incentives to counter gender socialization, and the extent to which job segregation has traditionally been based on employer practices rather than employee choices. $^{186}$

The Sears case highlighted crucial issues in feminist theory in a forum that was singularly ill-suited to address them. In insisting on simple causal explanations for complex employment patterns, prevailing doctrine distorted the controversies it sought to resolve. To determine whether Sears' practices did or did not "cause" women's underrepresentation, counsel pushed both Rosenberg and Kessler-Harris to present their historical interpretations as statements of fact. ${ }^{187}$ Broad generalizations about all women were marshaled to explain relatively small statistical disparities among a particular group of women-employees interested in Sears sales positions. ${ }^{188}$ Although the district judge seemed aware of the dangers of such generalizations, he applied his insight selectively. He criticized Kessler-Harris for her inability to quantify how many women illustrated the tendencies she described, but he did not subject Rosenberg's assertions to the same scrutiny. ${ }^{189}$

In effect, the Sears case caught feminists in a longstanding dilemma: either emphasizing or denying women's difference risks amplifying the disadvantages that follow from it. ${ }^{190}$ During the controversy following her trial testimony, Rosenberg criticized her opponents for insisting that employer discrimination was the only significant cause of gender disparities. In her view, the problem reflected in Sears was not the district court's "frank recognition that differences exist, but rather [that] many American[s were] unwilling to face those differences and do something about them."191

Yet, among those Americans were Sears managers who both relied on gender stereotypes in hiring decisions and declined to make workplace adjustments that would avoid penalizing women for their distinctive role. For exam-

186. See Hall, Women's History Goes to Trial: EEOC v. Sears, Roebuck and Company, 11 SIGNS 751 (1986); Scott, Deconstructing Equality-Versus-Difference: Or, the Uses of Poststructuralist Theory for Feminism, 14 FEMINIST STUD. 33, 40 (1988); see also Haskell \& Levinson, Academic Freedom and Expert Witnessing: Historians and the Sears Case, 66 TEX. L. REV. 1629 (1988); Kessler-Harris, Academic Freedom and Expert Witnessing: A Response to Haskell and Levinson, 67 TEX. L. REV. 429 (1988).

187. J. SCOTT, GENDER AND THE POLIIICS OF HISTORY 169-70 (1988). Any effort to introduce complexity or controversy served to undermine witness' testimony. Kessler-Harris, Equal Employment Opportunity Commission v. Sears, Roebuck and Company: A Personal Account, 25 FEMINIST REV. 46, 61 (1987).

188. J. ScoTT, supra note 187, at 169-70; Haskell \& Levinson, supra note 186, at 1634-36, 1653-57. (1989).

189. J. SCOTT, supra note 187, at 170; Williams, Deconstructing Gender, 87 MiCH. L. REV. 797, 817-18

190. M. MINOW, MAKING ALL THE DIFFERENCE: INCLUSION, EXCLUSION, AND AMERICAN LAW 19-23, 40-42, 56-60, 217-19, 375-77 (1990); D. RHODE, supra note 3, at 180-81, 306-13; J. SCOTT, supra note 187 , at 170 .

191. Rosenberg, What Harms Women in the Workplace, N.Y. Times, Feb. 27, 1986, at A23, col. 1. 
ple, one defense witness explained that women did not hold retail sales positions because they didn't like "going outside when it's snowing, raining or whatever." 192 To predict effectiveness in commission sales, Sears relied on tests that measured prospective employees" "vigor" by reference to their views towards boxing, wrestling, hunting, and swearing. ${ }^{193}$ Despite the company's professed commitment to affirmative action objectives, its management failed to explore policy initiatives that have in fact helped realize such objectives in comparable workplace settings: flexible schedules; childcare assistance; and special recruitment, training, and support programs for women in nontraditional occupations. ${ }^{194}$ If, as Sears emphasized, women generally didn't seek commission positions, neither did Sears actively seek women for those positions. ${ }^{195}$

Similar attitudes have been apparent in other employment discrimination cases in which courts have accepted gender stereotypes as an explanation for gender segregation. The unattractiveness of certain traditionally male occupations for female employees has been accepted as an inalterable "fact of life." 196 Decisionmakers have often viewed "sexist values," not employment practices, as solely responsible for gender stratification. ${ }^{197}$ Yet this perspective overlooks the vast array of data indicating that women's employment preferences are highly responsive to employment opportunities and that workplace cultures help shape female aspirations and achievements. ${ }^{198}$

In his closing argument, Sears' attorney urged the court to reject testimony by the government's "Ph.D.'s" in favor of "common sense"; no one could reasonably believe that a "monopsony of white men ... get[s] up every morning trying to find a way to discriminate against their wives, their daughters, their mothers, their sisters." 199 The problem for contemporary feminism lies in such caricatures of the problem-in assumptions that employers' discrimination is either responsible for all gender disparities or for none at all, that the sexes are either the same or different. The dynamics of gender cannot be reduced to such simple dualistic frameworks. Nor can women afford to replicate the failures of the protective labor era; feminists must not end up fighting each other over the extent of difference rather than uniting to challenge the disadvantages that difference perpetuates.

192. As quoted in Milkman, supra note 185 , at 382; see also Wiener, Exchange, NaTION, Oct. 26, 1985, at 410; Wiener, Women's History on Trial, NATION, Sept. 7, 1985, at 178.

193. See sources cited supra note 192.

194. Schultz, supra note 129, at 1789-93; Hall, supra note 186 , at 767-79 (written testimony of Alice Kessler-Harris).

195. See C. BACCHI, SAME DIFFERENCE: FEMINISM AND SEXUAL DIFFERENCE 119 (1990).

196. EEOC v. Mead Foods, 466 F. Supp. 1, 3 (W.D. Olkla. 1977); see also EEOC v. Korn Indus., 17 Fair Empl. Prac. Cas. (BNA) No. 74-1029, at 954, 959 (D.S.C. 1978) (no obligation for defendant to "waste its time and money trying to find women of extraordinary size, strength and stamina"), aff' d and remanded, 662 F.2d 256 (4th Cir. 1981).

197. See, e.g., Davis v. City of Dallas, 483 F. Supp. 54, 61 (N.D. Tex. 1979).

198. See evidence summarized in Schultz, supra note 129, at 1815-32; Hall, supra note 186 (citing testimony of Kessler-Harris).

199. Milkman, supra note 185 , at 385 (quoting Charles Morgan). 


\section{THE DENIAL OF RESPONSIBILITY}

A final version of the no-problem problem involves interpretative strategies that acknowledge gender injustice but deny responsibility for redressing it. These approaches take several forms. The first is to adopt a frame of reference that keeps the issue safely out of reach. Adherents acknowledge gender bias as a "serious problem," but remain confident that whatever happens in their home or workplace is not an instance of it. A related form of selective perception occurs among individuals who can see their connection to the problem but not to its solution. From this perspective, all plausible remedies lie elsewhere: government leaders look to employers, employers look to government, both look to families, husbands look to wives, and wives too often just stop looking. This last response reflects a final form of denial, which again acknowledges the problem, but rejects the possibility of any solution. However desirable in theory, the feminist agenda is simply unfeasible or unaffordable in practice. All of these approaches leave adherents in much the same place: gender inequality is a problem, but not their problem.

\section{A. Relocating the Problem}

\section{Strategies of Resistance}

Strategies for distancing gender bias operate somewhat differently among men and women. For many men, the social unacceptability of sexism, coupled with the inconvenience of eliminating it, have encouraged various techniques of self-deception. One common approach is to trivialize the issue; harassing, disrespectful, or condescending behavior is often dismissed as insignificant, while women who take offense are viewed as humorless and oversensitive. ${ }^{200}$ An alternative strategy is to find ways of pledging allegiance to the feminist cause that do not involve living with its implications.

One of the most costless techniques is to assert virtue by association. Men who have learned not to claim political correctness because "some of their best friends" are minorities feel no comparable pangs about basking in the liberation of their wives or daughters. If they have encouraged their spouses' decision to work, or their daughters' participation in Little League, surely no further evidence of enlightenment should be necessary. This is not to discount the importance of family experiences in increasing sensitivity to sexism. ${ }^{201}$ But

200. ABA COMM'N ON WOMEN, supra note 131, at 8-10; Schafran, supra note 167, at 57-68.

201. Neither should the effect of such experiences be overstated. See Crosby \& Herek, Male Sympathy with the Situation of Women: Does Personal Experience Make a Difference?, 42 J. SOC. IssUES, No. 2, 1986, at 55, 59-65 (finding no correlation between men's attitudes about sex discrimination and employment status of their wives or mothers or experiences of women in their own lives, but noting that men in high prestige occupations were more aware and disapproving of such discrimination than those in lower status occupations). 
it is to suggest that too many men view rhetorical support for women's aspirations as an adequate substitute for more tangible personal and political commitments.

For example, the skewed allocation of domestic responsibilities reveals wide disparities between many husbands' professed principles and daily practices. Women continue to assume about $70 \%$ of the domestic responsibilities in an average household and employed wives spend twice as much time on family obligations as employed men. ${ }^{202}$ Yet many husbands find ways to deny or rationalize their lighter burden. A recent in-depth survey of dual career families by Arlie Hochschild with Ann Machung illustrates a range of strategies. One is to revise reality in such a way that women's extra tasks appear matters of personal choice, not joint responsibility. Rather than accept an equal division of cleaning, cooking, or childcare obligations, some men redefine their share as unnecessary; they don't mind unmade beds or frozen pizza, and their infants will do just fine with extra time among their "friends" at daycare. ${ }^{203}$ The result for many women is that "I do my half, I do half of [my husband's] half, and the rest doesn't get done."204

A related strategy is to divide tasks so that some shares are "more equal" than others. One couple in Hochschild's and Machung's survey had settled on such a division for their household: the wife took responsibility for chores connected with upstairs and the husband for the downstairs and the dog. In their split level, the downstairs consisted of the garage. ${ }^{205}$ Men's shares are also more likely to consist of enjoyable tasks or those that can be scheduled at convenient times: playing with infants rather than changing their diapers or coping with their illnesses. ${ }^{206}$ When unexpected domestic problems arise, many men substitute emotional for practical support. The wife's role is to solve the problem while the husband's is to cheer her on from the sidelines with advice such as: "Handle it the best way you can honey. . . . I'm a hundred percent behind you."207

Such strategies build on more general cognitive tendencies involving the choice of reference groups. Where gender appears to be a relevant characteris-

202. See supra note 80 and accompanying text; see also B. BERGMAN, THE ECONOMIC EMERGENCE OF WOMEN 261-69 (1986); P. ENGLAND \& G. FARKAS, HOUSEHOLDS, EMPLOYMENT AND GENDER: A SOCIAL, ECONOMIC, AND DEMOGRAPHIC VIEW 94-99 (1986); M. GEERKEN \& W. GOVE, AT HOME AND AT WORK: THE FAMILY'S ALLOCATION OF LABOR 87-96 (1983); A. HOCHSCHILD \& A. MACHUNG, supra note 80 , at $21,271-73$; J. PLECK, supra note 80 , at 140-55; surveys summarized in D. RHODE, supra note 3 , at 174; Wallis, supra note 8.

203. A. HochSCHIL \& A. MACHUNG, supra note 80, at 202, 230-31, 260.

204. Id. at 259; see also J. PLECK, supra note 80, at 92 (suggesting that many wives may be willing to accept their husbands' unequal share of domestic responsibilities because of difficulties and conflict involved in getting them to perform tasks competently).

205. A. HOCHSCHILD \& A. MACHUNG, supra note 80 , at 43 .

206. See id. at 3-9; Coleman, The Division of Household Labor: Suggestions for Future Empirical Consideration and Theoretical Development, 9 J. FAM. ISSUES 132 (1988). See generally sources cited supra note 202.

207. A. HOCHSCHIL \& A. MACHUNG, supra note 80 , at 90 . 
tic, most individuals compare themselves to members of their own sex. ${ }^{208}$ In assessing domestic burdens, husbands typically find it convenient to view themselves in relation to other husbands rather than to their wives. ${ }^{209}$ From this perspective, unequal divisions of labor become easy to rationalize since they remain the norm rather than the exception. Once the problem of work/family conflict is conceptualized from a male reference point, the additional pressures facing women no longer seem unfair. As one husband in the Hochschild-Machung study pointed out, he did as much as many men. Although those other men's wives may have had fewer workplace obligations, why should he suffer just because his wife had chosen a demanding career? ${ }^{210}$

\section{Relative Deprivation}

Similar comparative strategies operate among women with similar results. A wide gap remains between many individuals' objective experience and their subjective perception of gender inequalities. For example, despite their grossly disproportionate share of domestic burdens, only about a quarter of recently surveyed wives reported that their husbands did less than their "fair share" around the home. ${ }^{211}$ Similarly, in studies in which a majority of women acknowledge gender discrimination in employment to be a problem, or where objective evidence points to that conclusion, most individuals do not believe that they personally have been victims. ${ }^{212}$ Autobiographical accounts reveal similar patterns: female authors will often recount numerous instances of unequal treatment in work and family spheres while maintaining that they have faced "no distinctive problems" on account of their sex. ${ }^{213}$

208. See F. CRosby, RElattve Deprivation AND WORKINg WOMEN 94 (1982) (women typically compare themselves to other women and $70 \%$ of females surveyed felt they were better off than other women); Major, supra note 105, at 101-05; Suls, Comparison Processes in Relative Deprivation: A Life-Span Analysis, in 4 RELATTVE DEPRIVATION AND SOCIAL COMPARISON, supra note 116, at 95, 97. For discussion of gender segregation in employment, see supra text accompanying notes 162-65.

209. A. HOCHSCHILD \& A. MACHUNG, supra note 80 , at 51 .

210. Id. at 40 .

211. Cowan, supra note 80 , at A14, col. 4; see also supra note 80 and accompanying text. For women's greater burdens, see sources cited supra note 202.

212. See F. CROSBY, supra note 208, at 13-18, 65-67, 94-115; Jackson, Relative Deprivation and the Gender Wage Gap, 45 J. SoC. ISSUES, No. 4, 1989, at 117, 119-20; Belkin, supra note 78, at 1 (70\% of women who worked fulltime felt women had equal or better chance of promotion where they worked). For example, in the Virginia Slims Opinion Poll, a majority of women felt that they had an equal chance with their male colleagues concerning salary and promotion; only $25 \%$ felt that their colleagues did not look on them as an equal. 1985 VIRGINIA SLIMS POLL, supra note 79, at 27-28; see also Samborn, Many Americans Find Bias at Work, Nat'l L.J., July 16, 1990, at 1, cols. 1-2 (78\% of surveyed Americans indicated that they believed some, all, or most employers are guilty of discriminatory practices, but only one-quarter claimed to have experienced such discrimination, and only $8 \%$ of those reported gender bias). On women's lack of self-identification or involvement as feminists, see supra text accompanying notes 8-9.

213. See Hochschild, Making lt: Marginality and Obstacles to Minority Consciousness, in WOMEN AND SUCCESS, THE ANATOMY OF ACHIEveMENT 194, 195 (R. Knudsen ed. 1974) (quoting Mildred Dresselhaus, one of few women in electrical engineering at MIT, who also reported that her male adviser had been totally unsympathetic and had provided no assistance with her thesis); see also F. CROSBY, supra note 208 , at $13-18,65-67,94-115$. 
In explaining this denial among women, theories of relative deprivation provide some assistance. The central premise of such theories is that felt grievances are a function not simply of objective circumstances but of cognitive and emotional factors. While theorists differ on the importance they ascribe to particular factors, those considered most likely to foster a sense of deprivation are: a desire for some object; a perception that others in a comparable reference group have it; a sense of entitlement to it; an absence of self-blame for the failure to possess it; and a sense that in the past the object was attainable and that in the future it will not be. ${ }^{214}$ These conditions are, in turn, influenced by the structural and ideological forces that underpin gender roles.

As a threshold matter, sex-based socialization patterns may diminish women's desire for the same occupational rewards or limited domestic roles that are available to men. Most research suggests that women have placed lower priority than men on objective forms of recognition in employment such as money, status, or power and have attached higher importance to relational concerns such as opportunities to help or work with others. ${ }^{215}$ Since many women also believe that caring for a home and children are their most rewarding pursuits, their disproportionate assumption of domestic burdens may not always feel unjust. ${ }^{216}$ Women's perceptions of fairness are also influenced by their reliance on same-sex reference groups in contexts in which gender appears relevant. ${ }^{217}$ As long as most family responsibilities continue to be typed as "women's work" and the American paid (and unpaid) labor force remains highly gender segregated, many women will fail to make gender comparisons that would reveal gender hierarchy.

Other structural factors encourage such selective perception. Historical and social science research makes clear that individuals who feel powerless to affect

214. See F. CROSBY, supra note 208, at 7, 22-23. For overviews of relative deprivation, see generally W. RUNCIMAN, RELATIVE DEPRIVATION AND SOCIAL JUSTICE (1966); 4 RELATIVE DEPRIVATION AND SOCIAL COMPARISON, supra note 116. These theories build on longstanding observations about human discontent and the frequent gap between subjective perceptions and objective conditions. Aristotle hypothesized that we could predict individuals' satisfaction from their neighbors' conditions, and Marx described how a house became a hovel when a palace was constructed next door. F. CROSBY, supra note 208, at 16.

According to some theorists, the factors noted in the text operate differently in different contexts and cultures, and not all are preconditions to resentment. See F. CROSBY, supra note 208, at 157-60; Crosby, Muehrer \& Loewenstein, Relative Deprivation and Explanation; Models and Concepts, in 4 RELATIVE DEPRIVATION AND SOCIAL COMPARISON, supra note 116, at 17, 19, 25.

Under a similar "equity" theory, deprivation assertedly results when an individual's ratio of rewards to investments and costs appears smaller than others' ratios. See G. HOMANS, SOCIAL BEHAVIOR: ITS ELEMENTARY FORMS 248-57 (1974); E. WALSTER, G. WALSTER \& E. BERSCHEID, EQUTTY: THEORY AND RESEARCH (1978); Wheeler \& Zuckerman, Commentary, in SOCLAL COMPARISON PROCESSES: THEORETICAL AND EMPIRICAL PERSPECTIVES 335, 351-54 (J. Suls \& R. Miller eds. 1977); Equity Theory: Toward a General Theory of Social Interaction, 9 ADVANCES IN EXPERIMENTAL SOC. PSYCHOLOGY (L. Berkowitz \& E. Walster eds. 1976).

215. See supra text accompanying note 128.

216. S. EVANS, supra note 60 , at 226 (1975 Harris Survey found that $51 \%$ of women believed that taking care of home and children was more rewarding than having a job); supra text accompanying notes $65 \& 79$.

217. See supra note 208. 
their subordinate situation tend to avoid comparisons that suggest its unfairness. ${ }^{218}$ Such dynamics inhibit a sense of injustice based on race, as well as gender. The point was well illustrated by an organizer for an impoverished Black community who reported being "very content" with her poverty-line wages since she had more than her neighbors. When asked about white residents in a wealthy area clearly visible from her front porch, the organizer explained, "[M]y life is here. I don't think about them."219

Perceptions of entitlement and blame can also discourage perceptions of a problem. ${ }^{220}$ Stereotypes about the quality and value of women's work often diminish individuals' sense of their own merit. ${ }^{221}$ As research on cognition makes evident, it is generally easier to conclude that "just desserts" have been violated for abstract groups than for particular individuals, including oneself. ${ }^{222}$ For women to see themselves as victims imposes other costs as well. Faced with a potential loss of efficacy and self-esteem, together with the unpleasantness of identifying a perpetrator of injustice, many individuals prefer to revise their sense of merit or blame. ${ }^{223}$

A final factor influencing women's sense of injustice involves their expectations. Individuals are most likely to feel aggrieved when they believe that a desired object or status was available in the past and will not be in the future. ${ }^{224}$ A central problem in generating perceptions of a problem among women is that their opportunities have generally been expanding. According to contemporary opinion polls, most individuals believe that the situation for women will continue to improve. ${ }^{225}$ For gender issues affecting the broadest segments of the public - employment, family obligations, and sexual abuse-the future looks more promising than the past. Except on questions of abortion,

218. B. MOORE, INJUSTICE: THE SOCLAL BASES OF OBEDIENCE AND REVOLT 455-59, 471-72 (1978); Martin \& Murray, Distributive Injustice and Unfair Exchange, in EQUTYY THEORY, supra note 116, at 169; Wills, supra note 117, at 264-68; see also F. PARKIN, supra note 11, at 60-67.

219. As quoted in Martin, The Tolerance of Injustice, in 4 RELATIVE DEPRIVATION AND SOCIAL COMPARISON, supra note 116.

220. See text accompanying supra notes 12-13; sources cited supra notes 108, 116, 214 \& 218; text accompanying infra note 226; infra note 230 and accompanying text.

221. See supra text accompanying notes 108, 115; infra text accompanying notes 226-32.

222. As Crosby explains, the concept of deserving presupposes categorical comparison. At its core is the belief that like cases should be treated alike, which assumes a classification into groups that can be compared along relevant dimensions. The more we know about particular individuals and their unique set of attributes and behavior, the more difficult it is to consider them as representatives of particular groups. F. CROSBY, supra note 208 , at 161 .

223. Id.; K. BUMILLER, THE CIVIL RIGHTS SOCIETY: THE SOCIAL CONSTRUCTION OF VICTMMS 27, 36, 52-53, 94-99 (1988); Olson \& Hazelwood, Relative Deprivation and Social Comparison: An Integrative Perspective, in 4 RELATIVE DEPRIVATION AND SOCIAL COMPARISON, supra note 116, at 1, 8-9 (individuals tend to process information and select reference groups in ways that will validate their own abilities and enhance their own self-esteem); see also Unger \& Sussman, "I and Thou": Another Barrier to Social Change?, 14 SEX ROLES 629, 630 (1986) (discussing individuals' greater awareness of discrimination against others than against themselves and relating it to people's greater tendency to attribute personal efficacy and control to themselves than to others).

224. See F. CROSBY, supra note 208, at 22; T. GURR, WHY MEN REBEL $317-55$ (1970).

225. See 1985 VIRGINIA SLIMS POLL, supra note 79, at 1; 1980 VIRGINIA SLIMS POLL, supra note 79, at $18-19$; Belkin, supra note 78. 
where threats of curtailment have mobilized large numbers of women, a sense of complacency prevails. Most contexts in which women's situation has demonstrably worsened have involved discrete subgroups, typically those already disadvantaged by class, race, or ethnicity. As for issues affecting those groups, such as the feminization of poverty, the perception among many women, as well as men, has been that it's "not my problem."

\section{B. Relocating the Solution}

\section{Victimizing the Victim}

A second way of distancing gender inequality as a problem is to relocate responsibility for causing or addressing it. One common approach is to blame the victim, a tendency reinforced by the "just world" assumptions noted earlier. ${ }^{226}$ Just as members of subordinate racial and economic groups are presumed to deserve their status, ${ }^{227}$ women are often held accountable for the inequality they experience.

For example, sexual abuse will appear less threatening if women are responsible for provoking or inviting it. In clinical experiments, individuals will often incorrectly recall facts about victims' complicit or provocative conduct in order to avoid concluding that an innocent person has suffered..$^{228}$ That same tendency is apparent in contexts such as sexual harassment, domestic violence, and rape. Despite federal research suggesting that about $85 \%$ of all working women will at some point experience workplace harassment, many observers persist in believing that the problem only confronts employees "who ask for it." 229 Under similar reasoning, rapes are often attributed to women's seductive clothing or reckless conduct. ${ }^{230}$ In one recent Wisconsin case, the

226. See supra text accompanying notes 12-13.

227. ROPER CENTER FOR PUBLIC OPINION RESEARCH, ABC-WASHINGTON POST RACE RELATIONS 198189 (Oct. 3, 1989) discussed in Morin, Fewer Whites Voicing Racial Bias; Poll Comparison Suggest Moderation of Attitudes Toward Blacks, Wash. Post, Oct. 26, 1989, at A18, col. 1 (56\% of whites surveyed in 1989 agreed that many of problems facing Blacks today "are brought on by blacks themselves," and 43\% agreed that Blacks lagged behind whites economically because most Blacks "don't have the motivation or will-power to pull themselves out of poverty"). For discussion of comparable biases on class issues, see M. KATZ, supra note 7, at 6-16.

228. See M. LERNER, supra note 12, at 21 (citing studies); Apsler \& Friedman, supra note 13; Comer \& Laird, supra note 13, at 93; Wortman, Causal Attributions and Personal Control, in 1 NEW DIRECTIONS IN ATTRIBUTION RESEARCH 23-28 (J. Harvey \& W. Ickes eds. 1976). So too, in experimental studies in which a victim receives painful electric shocks, observers who have no opportunity to prevent the shocks tend to deny their magnitude. Despite information to the contrary, subjects will maintain that the shocks are mild or that the victim knew what she was getting into and assumed the risk. M. LERNER, supra note 12 , at 52 .

229. N. MCGLEN \& K. O'CONNOR, WOMEN's RIGHTS: THE STRUGGLE FOR EQUALITY IN THE NINETEENTH AND TWENTIETH CENTURIES 186 (1983) (quoting Phyllis Schlafly); see also D. RHODE, supra note 3, at 232-35.

230. See G. LAFREE, RAPE AND CRIMINAL JUSTICE: THE SOCIAL CONSTRUCTION OF SEXUAL ASSAULT 95-107, 208-26 (1989); J. MARSH, A. GEIST \& N. CAPLAN, RAPE AND THE LIMTS OF LAW REFORM 61 (1982); REPORT OF THE NEW YORK TASK FORCE ON WOMEN IN THE COURTS 68-73 (1986) [hereinafter 
trial judge even managed to lay blame on a five-year-old child whom he characterized as an "unusually promiscuous young lady."231 Law enforcement and judicial officials have similarly viewed victims of domestic violence as accountable for their own abuse: "[A]ll they have to do is get out of the house."232 Why women should be the ones to leave, how they can support themselves and their children, and what will prevent further physical retaliation are questions discreetly overlooked.

Such responses compound women's injury by discounting its existence. Many individuals are victimized twice: first by sexual abuse and then by the process of proving it. Even decisionmakers who acknowledge the problem have been more disposed to praise than subsidize the necessary responses. Resources for rape crisis centers and battered women's programs remain grossly inadequate while decisionmakers in each branch of government perennially defer to those in other branches to find "creative funding" for such initiatives. ${ }^{233}$

\section{Pay Equity}

This latter response points to a related strategy of denial that locates the problem everywhere or anywhere else. A representative case study involves pay equity. In general, the concept encompasses various job evaluation strategies that identify characteristics relevant to compensation (such as skill, responsibility, and working conditions) and then evaluate existing salary levels in light of those characteristics. ${ }^{234}$ Such techniques have frequently revealed the undervaluation of women's work noted earlier, and highlighted comparisons such as childcare attendants who earn less than parking lot attendants and nurses who

NEW YORK TASK FORCE]; Aiken, Differentiating Sex from Sex: The Male Irresistible Impulse, 12 N.Y.U. REV. L. \& SOC. CHANGE 357, 376 (1984); Spencer, Sexual Assault: The Second Victimization, in WOMEN IN THE CoURTs (1987). For a recent illustration, see Grizzard, What Do They Mean, Advertising for Sex, Bristol Herald Courier/Virginia-Tennessean, Nov. 2, 1989, at 8B, col. 1 (discussing rape acquittal where jurors believed that victim "advertised for sex" by wearing mini skirt without undergarments).

231. As quoted in Schafran, Documenting Gender Bias in the Courts: The Task Force Approach, 70 JUDICATURE 280, 284 n.17 (1987); see also REPORT OF THE FLORIDA SUPREME COURT GENDER BIAS STUDY COMM'N 140-41 (1990) (reporting widespread belief that sexual molestation victims precipitate abuse).

232. Schafran, supra note 231, at 283-84; see also MARYLAND SPECIAL JOINT COMM., GENDER BIAS IN THE COURTS 2-3, 9 (1989); NEW YORK TASK FORCE, supra note 230, at 68-73; Waits, supra note 2, at 299-301, 311-15.

233. See B. DECKARD, THE WOMEN's MOVEMENT 439-40 (3d ed. 1983); U.S. COMM'N ON CIVIL RIGHTS, UNDER THE RULE OF THUMB: BATTERED WOMEN AND THE ADMINISTRATION OF JUSTICE 81-90 (1982); ATTORNEY GENERAL'S TASK FORCE ON FAMILY VIOLENCE, FINAL REPORT 60 (1984).

234. See infra note 246. 
earn less than tree trimmers. ${ }^{235}$ These strategies have also aroused heated opposition, often by critics who acknowledge gender bias as a problem, but deny any obligation to respond.

Once again, Yale's experience has been no exception. That became apparent in a 1984 union organizing campaign, which marked the first successful effort to unionize predominantly female clerical and technical staff at a major university. In part because they had not been organized, skilled women were underpaid in comparison both to unskilled males within the university and to skilled women in similar positions outside it. Confronted by these depressed wage rates and the hardship they presented, especially for female-headed households, the University Provost responded, "I know that one can't live the way one would like to, or the way one would like one's family to live, on a Yale clerical and technical salary. That's a national problem, which Yale can't be expected to solve."236

Who exactly is responsible for solving it remains unclear. Federal legislators have been unwilling to send enforcement officials "trooping around all over the country ... harassing business with their various interpretations of the term 'comparable.' "237 Major governmental and business leaders have painted pay equity as absurd or abhorrent, the "looniest idea since Looney Tunes," or an invitation to runaway inflation and a centrally planned economy. ${ }^{238}$ Most courts have been equally unenthusiastic. As one trial judge explained:

We're confronted with a history which I have no hesitancy at all in finding has discriminated unfairly and improperly against women. But Congress did not, in my judgment, decide that we were going to roll aside all history and that the Federal Courts should take over the job of leveling out centuries of discrimination....

235. See Lewin, Small Tots, Big Biz, N.Y. Times, Jan. 29, 1989, § 6 (Magazine), at 30, col. 1; sources cited supra notes 108-12; see also Steinberg, The Social Construction of Skill, in WORK AND OCCUPATIONS (forthcoming) (school librarians paid less than groundskeepers and occupations such as dog pound attendant and parking lot attendant are rated as more difficult and therefore as deserving higher compensation than childcare and nursery school worker). See generally Phillips \& Taylor, Sex and Skill: Notes Towards a Feminist Economics, 6 FEMINIST REV. 79 (1980) (arguing that skill is "ideological category" imposed on work by virtue of power of particular groups of workers and noting that hierarchical classifications of male and female jobs often bear little relationship to workers' ability or training).

236. As quoted in Taylor, Women Workers and the Yale Strike, 11 FEMINIST STUD. 465, 475 (1985).

237. 108 CONG. REC. 14,768 (1962) (remarks of Rep. Landrum on Equal Pay Act of 1962); see also 1963 U.S. CODE CONG. \& ADMIN. NEWS 690-92.

238. Lawson, Women in State Jobs Gain in Pay Equity, N.Y. Times, May 20, 1985, at C12, col. 2 (quoting Civil Rights Commission Chairman Clarence Pendleton, Jr.); see also M. LEvIN, supra note 71, at 145-46; Weiler, The Wages of Sex: The Uses and Limits of Comparable Worth, 99 HARV. L. REV. 1728, 1729 (1986) (quoting Ronald Reagan dismissing concept of comparable worth as "cockamamie idea"); Remick \& Steinberg, Technical Possibilities and Political Realities: Concluding Remarks, in COMPARABLE WORTH AND WAGE DISCRIMINATION, supra note 105, at 285, 289-90 (discussing criticism that comparable worth will destroy free market as basic wage-setting mechanism). 
... If we are to have ... the Big Brother looking over our shoulder who is going to dictate our day-to-day ways of life ... [i]t's not going to come, at least, from this court. ${ }^{239}$

From this perspective, if women workers have a problem with current wage rates, the solution lies with those women. ${ }^{240}$ If female nurses think they're underpaid relative to male sign painters, let them paint signs.

In fact, sign painting is part of what women need to do, although not as a full-time occupation. The most successful comparable worth strategies in this country generally have depended on the mobilization of women through collective bargaining and legislative lobbying. Pay equity can create a powerful organizing issue by raising women's expectations, self-esteem, and bargaining skills. ${ }^{241}$ The Yale struggle is a representative example. Claims about the undervaluation of female-dominated jobs helped unionize clerical and technical staff, mobilize a strike, and secure substantial raises as a consequence. ${ }^{242} \mathrm{~A}$ growing number of comparable worth initiatives at the state and municpal levels have similarly resulted in modest gains for women and minorities. ${ }^{243}$ Such gains have come without triggering the major inflation, inefficiency, and unemployment that critics have predicted. ${ }^{244}$

The point of these strategies is to locate at least partial responsibility for remedying gender bias with decisionmakers who have, in fact, the power to do so. In this effort, the law can play only a limited role, but a larger one than many opponents have acknowledged. Courts may not be an ideal forum in which to resolve arguments about the inherent worth of particular jobs. ${ }^{245}$ Such evaluations depend on essentially political determinations about how to categorize various job characteristics and how to rank particular jobs in terms of such characteristics. These are questions on which reasonable decisionmakers often disagree. Since judges have no principled basis for resolving such disputes, they are generally better addressed in more representative legislative or

239. Lemons v. City \& County of Denver, 17 Fair Empl. Prac. Cas. (BNA) No. 76-W-1156, at 906, 908, 914 (1978); see also Watson v. Fort Worth Bank \& Trust, 487 U.S. 977, 999 (1988) (courts are less competent than employers to structure compensation practices).

240. See Manufacturers Group Hits Comparable Worth in Pay, L.A. Times, Nov. 24, 1984, \& 1, at 24, col. 1 (quoting Alexander B. Trowbridge, President, National Association of Manufacturers).

241. See J. ACKER, DONG COMPARABLE WORTH: GENDER, ClasS, AND PAY EQUTTY (1989); S. EVANS \& B. NELSON, WAGE JUSTICE: COMPARABLE WORTH AND THE PARADOX OF TECHNOCRATIC REFORM (1989); Steinberg, Radical Challenges in a Liberal World: The Mixed Success of Comparable Worth, 1 GENDER \& SOC'Y 466 (1987).

242. Taylor, supra note 236, at 479-82; Drogin, Comparable Worth at Center of Yale Strike, L.A. Times, Nov. $18,1984, \S 1$, at 5 , col. 1 .

243. See, e.g., NATIONAL COMM'N ON PAY EQUTTY, PAY EQUTTY: AN IsSUE OF RACE, ETHNICTT, AND SEX 86-104 (1987); Clauss, Comparable Worth-The Theory, Its Legal Foundation, and the Feasibility of Implementation, 20 U. MICH. J.L. REF. 7, 90-95 (1986); Rothchild, Pay Equity-The Minnesota Experience, 20 U. MICH. J.L. REF. 209, 214-15 (1986).

244. See generally sources cited supra notes $241 \& 243$. The typical cost of comparable worth reforms has been around 5-10\% of total wage rates phased in over a number of years. Hartmann, Comparable Worth and Women's Economic Independence, in INGREDIENTS, supra note 4, at 256.

245. Rhode, supra note 141, at 1221-22; see also infra note 246. 
collective bargaining contexts. ${ }^{246}$ Not all pay equity claims, however, involve issues of inherent worth. Some seek only to ensure that employers are consistent in implementing their own chosen compensation criteria and evaluation systems, irrespective of the racial or gender composition of particular occupations or the pay at which individuals are willing to work. ${ }^{247}$

Yet in this, as in other contexts, equality in formal requirements does not necessarily ensure equality in social practice. Unless efforts are made to involve workers and build coalitions among them, comparable worth can become a means of slightly reformulating but then rigidifying wage hierarchies. In the implementation of some pay equity initiatives, job evaluation schemes have become bargaining tools that managers have harnessed for their own purposes and that have divided union members by class as well as gender. ${ }^{248}$

Thus, the greatest danger is not that comparable worth will prove too radical, but rather that it will not prove radical enough. Once again, if the problem is too narrowly defined, concerns about gender could displace concerns about class, race, and ethnicity. The result may be a slightly modified compensation structure in which the "haves" still come out far ahead, although more women are among them. By cloaking job evaluation in a mantle of seemingly

246. To assess intrinsic worth, decisionmakers typically determine a priori the weight of factors that should serve as the basis for salary differentials. Experts will rank job characteristics such as skill, responsibility, and working conditions, and then assign points to particular jobs based on their weighted characteristics. Compensation levels can then be readjusted to assure parity between jobs with similar ratings. The strengths of this system also establish its limitations. By rating jobs without regard to existing pay rates, such techniques often expose underpayment of predominantly female occupations. Yet, how much weight should attach to particular characteristics, and how particular jobs should be rated in terms of those characteristics, are judgments about which experts often disagree. Courts have no principled basis for resolving such disputes and litigation is an expensive and often ineffective forum for representing all relevant perspectives. See sources cited in E. PAUL, EQUTTY AND GENDER: THE COMPARABLE WORTH DEBATE 55-56 (1989) (noting disparities in evaluation of similar positions by different state governments); Rhode, supra note 141 , at $1230-39$.

247. Under policy-capturing evaluation systems, the relative worth of particular job characteristics is determined by analysis of existing wage rates. Experts use statistical regression techniques to establish the relative weight of factors in predicting correct wages. Those wage rates are then reexamined to determine whether employers have consistently employed their own weighting system across job categories-irrespective of the race, gender, and ethnicity of employees and the pay at which they are willing to work. The strengths of this system also impose its limitations. By relying on the employer's own standards to establish relative worth, policy-capturing approaches avoid more divisive issues about the intrinsic value of particular jobs. Such approaches have revealed racial and gender biases, and could be the basis of legal liability. See, e.g., THE WAGE GAP, supra note 4, at 86-104; Clauss, supra note 243, at 52-54; Rhode, supra note 141, at 1228-40. However, since a policy-capturing approach uses existing wage rates to assess the relative importance of job characteristics, it will also reflect the undervaluation that has historically affected femaleand minority-dominated jobs. A more fundamental challenge to current norms is possible with $a$ priori job evaluation techniques that focus on intrinsic worth, implemented through legislative and collective bargaining initiatives and involving workers in the evaluative process. See supra note 246.

248. For example, in both Minnesota and Oregon, implementation at the local level left workers confused and divided. Many managers found ways to use job evaluation to redistribute rather than augment salary levels and to weaken the collective bargaining process. J. ACKER, supra note 241, at 100-43, 167-69, 200-07; Evans \& Nelson, Comparable Worth: The Paradox of Technical Reform, 96 FEMINIST STUD. 171, 180-86 (1989). 
scientific objectivity, incremental reforms can insulate wage hierarchies from more searching review. ${ }^{249}$

A more hopeful alternative is that feminism will broaden understandings of the problem to be addressed. At issue is not simply gender equality, but also social priorities. How much disparity across salary levels is essential to promote workplace efficiency? Are we comfortable with a society that pays more for parking lot attendants than childcare attendants, whatever the male/female composition of those jobs? By making these questions visible and forcing them onto legislative and collective bargaining agendas, the pay equity campaign could promote progress for all subordinated groups. In that sense, comparable worth could be a radical concept, but not in the sense critics usually claim. It need not imply a centrally planned economy, but it can invite us to rethink the alternatives.

\section{Resisting Alternatives}

A final, and in many ways the most debilitating, form of denial is to acknowledge gender inequality as a problem but to resist the possibility of solution. This strategy, which operates at individual, institutional, and societal levels, typically concedes feminist premises while dismissing feminist responses. The effect is to preempt debate by recasting its terms. Sex-based injustice becomes one more lamentable but inevitable fact of life. And as thenPresident Carter once explained in justifying the denial of federal abortion assistance to impoverished women: "[T]here are many things in life that are not fair."250

\section{Individual Responses}

At the individual level, a common strategy of resistance is to invoke cultural determinism. Men who grew up under traditional norms are often presumed to be incapable of change. Explanations that would be viewed unacceptable in contexts of race pass without objection in contexts of gender. If men are not comfortable working with or for women, or doing "women's work" around the house, it's a regrettable byproduct of our sexist culture. As one of the husbands in the Hochschild-Machung study explained, he needed someone to take care

249. J. ACKER, supra note 241, at 100-01, 167-69, 202, 208-12; Brenner, Feminist Political Discourses: Radical Versus Liberal Approaches to the Feminization of Poverty and Comparable Worth, 1 GENDER \& SoC'Y 447 (1987). In relying on evaluation systems to give legitimacy and an "aura of objectivity" to their claims, but then losing control over the design or choice of such systems, pay equity proponents have been caught in no-win situations. To achieve some tangible gains and to avoid losing face, proponents have had to accept evaluation frameworks that incorporate bias, reinforce wage hierarchies, and solidify managerial power. See Steinberg, Job Evaluation and Managerial Control: The Politics of Technique and the Techniques of Politics (May 1990) (unpublished manuscript).

250. Law, Rethinking Sex and the Constitution, 132 U. PA. L. REV. 955,1016 n.219 (quoting President Jimmy Carter, N.Y. Times, July 13, 1977, at A10, col. 4). 
of "[my] MCP [male chauvinist pig] needs-which I can't help having growing up in this kind of society."251

A second line of defense is to take men's aspirations and constraints as given, while assuming women's are negotiable. Husbands who won't reduce their workplace obligations to accommodate family responsibilities frequently develop such selective perception. For them, to make career concessions is simply not an option. This perspective denies the role of choice even as it is exercised. In the view of many professionals: "It's not a question of what I want."252 After all, a "demanding practice is a demanding practice." ${ }^{253}$

\section{Institutional Responses}

Similar perceptions operate at the institutional level as well. Only a small fraction of American employees have adequate access to childcare assistance, parental leaves, flexible schedules, or decent part-time work. ${ }^{254}$ Such options are commonly dismissed as unworkable or unaffordable, and the cost of even relatively minor adjustments often appears prohibitive. The point was recently illustrated by a law firm associate who returned to full-time work while still nursing her child. To minimize inconvenience for the firm, she extracted breast milk with a pump, rather than breastfeed during working hours. This did not satisfy the firm's partners, one of whom noted that at her billing rates, the milk she was providing cost $\$ 10$ per ounce. His message was that perhaps she and her husband "can afford that, but the firm can't."255

Such claims build on longstanding ideological traditions. Almost every major effort to promote gender equality has been painted as economically unfeasible, and almost no cost has been too trivial to include. The extended history of the "potty problem" is perhaps the most obvious illustration. Throughout the late nineteenth and early twentieth centuries, the absence of adequate lavatory facilities appeared as an insurmountable obstacle to gender integration. Institutions including the Yale Medical School, the Princeton

251. As quoted in A. HochSCHILD \& A. MACHUNG, supra note 80 , at 119 .

252. Id. at 113 .

253. Kerlow, D.C. Firms Exceed Average in Women Partners, Legal Times, Feb. 13, 1989, at 11, col. 4 (quoting June Gertig). As Keriow's article makes clear, the perspective is not limited to men. And when women echo the view that professional demands cannot be adjusted to accommodate substantial family commitments, it encourages the perception that existing norms are gender neutral. $C f$. supra text accompanying note 179.

254. Hearings Before the Subcomm. on Human Resources of the House Comm. on Education and Labor, 100th Cong., 2d Sess. 279 (1988) (testimony of Dr. Heidi Hartmann); U.S. DEP'T OF LABOR, CHIID CARE: A WORKPLACE ISSUE 1-10(1988); S. KAMERMAN \& A. KAHN, THE RESPONSIVE WORKPLACE (1987); Dowd, supra note 181; Dowd, supra note 181: Finley, Transcending Equality Theory: $A$ Way Out of the Maternity and Workplace Debate, 86 CoLUM. L. REV. 1118 (1986); Marx \& Seligson, Child Care in the United States, in THE AMERICAN WOMAN, supra note 7, at 132, 143-50; Strober \& Dornbusch, Public Policy Alternatives, in FEMINISM, CHILDREN AND THE NEW FAMILIES 334-41 (S. Dornbusch \& M. Strober eds. 1988); Taub, supra note 181 .

255. Sylvester, How Firms Cope with Motherhood, Nat'1 L.J., Nov. 7, 1983, at 1, col. 3. 
graduate program, the Brooklyn and Bronx bar associations, prominent Wall Street law firms, and various all-male clubs were unable to circumvent this obstacle for significant periods. ${ }^{256}$ As one law firm partner explained to a female applicant during the 1930's, much as his firm would like to hire her, the logistical difficulties were simply too great; she couldn't use the attorney's bathroom, she couldn't be relegated to the secretaries' bathroom, and the firm couldn't afford to build a new one. ${ }^{257}$ Variations of the same theme continue to appear as justifications for all-male associations. As Washington Metropolitan Club officials regretfully reported, "Much as we love the girls, we just don't have the lavatory facilities to take care of them."258

The point of such examples is not to encourage denials of another form. The feminist agenda does entail significant costs, and the financial constraints facing many organizations cannot be discounted. But too often the calculations have begun with a skewed balance sheet that fails to take into account the less visible costs and consequences of current practices. Failure to address genderrelated concerns results in lost talent, heightened turnover, and diminished productivity in the current labor force, as well as inadequate support for the children who will shape its future.

\section{Societal Responses}

Systematic miscalculations are also apparent at the societal level. Adequate parental leave, childcare, maternal health, birth control, and vocational training initiatives are typically evaluated in terms of short-run expenditures, which all too often our nation "cannot" afford. The long-term costs of this judgment are underestimated or overlooked. Parental leave legislation is a classic example. In justifying his veto of the proposed Family and Medical Leave Act of 1990, President Bush expressed concern for the costs to American business in an "increasingly complex and competitive global marketplace."259 Yet if we are to maintain our competitive position, it is critical that we invest now in the generations that will sustain us later. Experts universally agree that close attachments to a primary caretaker are critical to early child development. ${ }^{260}$ Our unwillingness to require even minimal unpaid parental leaves sets us apart

256. C. EPSTEIN, WOMAN'S PLACE: OptIONS AND LiMTSS IN PROFESSIONAL CaREERS 185 (1970); D. RHODE, supra note 3, at 284-85; Baserga, The Early Years of Coeducation at the Yale University School of Medicine, 53 YALE J. BIOLOGY \& MED. 181 (1980). At the Yale Medical School, the problem was finally surmounted when the father of a prospective female student donated funds for a ladies' room. Id.

257. C. EPSTEIN, supra note 53, at 85.

258. As quoted in Alpern, Clubs: The Ins and Outs, NewsweEK, Jan. 10, 1977, at 19.

259. 136 CONG. REC. H4451 (July 10, 1990) (statement of President Bush). For similar arguments against parental leave, see sources cited in D. RHODE, supra note 3, at 356 n.27; Pytte, House Passes Parental Leave; White House Promises Veto, CoNG. Q., May 12, 1990, at 1471 (quoting Rep. Lay's view that such legislation would provide "another nail in the coffin of competitiveness and productivity").

260. Brazelton, Issues for Working Parents, in THE PARENTAL LEAVE CRISIS: TOWARD A NATIONAL POLICY 36 (E. Zigler \& M. Franke eds. 1988). 
from every western industrialized nation except South Africa. ${ }^{261}$ In the long term, such a policy cannot help but compromise the economic objectives it purports to serve.

Moreover, calculations that focus only on the costs to business obscure the costs to vulnerable children, disabled workers, elderly dependents, and their largely female caretakers. Estimates of the total personal as well as societal losses resulting from the absence of adequate caretaking structures make clear the irrationality of current policies. ${ }^{262}$

Such denials of collective solutions to gender-related problems reverse one of feminism's central principles. The effect is to personalize the political and to miscast individual rights as a substitute for societal initiatives.

\section{Reformulating the PROBLEM: REASSESSing THE RESPONSE}

For contemporary feminism, these ideologies of denial pose problems on two levels. The first involves dilemmas of difference: how to affirm sex-linked attributes without overgeneralizing their content and perpetuating their constraints. A second challenge involves political struggle: how to build collective organizations in an individualistic culture and encourage coalitions among a diffuse and heterogeneous community.

\section{A. Dilemmas of Difference}

\section{The Validation of Difference}

Throughout its history, the women's movement has attempted to validate as well as challenge gender differences. The result has been certain predictable tensions in feminist theory and practice. As previous discussion noted, many early activists predicated their claims for equality on women's distinctive nurturing qualities and concerns. In the 1970's and 1980's, similar arguments gained greater prominence. Increasing numbers of theorists began emphasizing the centrality of sexual difference although disagreeing about its origins and consequences. Their discourse reflects a broad range of perspectives that are difficult to fit under any single label. For present purposes, it is enough to summarize certain common themes that can be loosely grouped under the term "relational feminism." 263

What unites these approaches is a focus on women's reproductive role and the nurturing relationships that it has encouraged. Some feminists attach

261. Pytte, supra note 259 , at 1474 . For discussion of the inadequacy of current policies, see sources cited supra notes $177,181$.

262. R. SPALTER-ROTH \& H. HARTMANN, UNNECESSARY LOSSES: THE COSTS TO WORKERS IN THE STATES OF THE LACK OF FAMILY AND MEDICAL LEAVE (1988).

263. See Offen, Defining Feminism: A Comparative Historical Approach, 14 Signs 119, 134 (1988). 
overarching significance to biological difference. ${ }^{264}$ Others give varying emphasis to socialization, role constraints, or subordination; their frameworks underscore women's need to obtain status, control, and approval through attachments to others or conformity to existing norms. ${ }^{265} \mathrm{~A}$ third approach draws on psychoanalytic theory. According to this last account, children develop closer attachments to a primary caretaker of the same sex. Individuals who form strong attachments in early life will be more likely later to define themselves in relation to others and to develop close nurturing bonds. Since most primary caretakers have been and continue to be female, girls grow up with a greater inclination toward and capacity for caretaking roles. ${ }^{266}$

A final approach, which has been most influential in legal arenas, focuses not on the origins of gender difference but on its normative significance. From this perspective, the problem for contemporary western women stems less from the exaggeration of difference than from its devaluation. This school of thought, popularized by Carol Gilligan, argues that conventional moral and legal theories have placed too great a priority on abstract rights, and too little on concrete relationships. Based on empirical and qualitative research, Gilligan claims that women tend to reason in "a different voice," which is especially attentive to care, cooperation, and context in the resolution of human problems. ${ }^{267}$ Building on her approach, some feminists suggest that female lawyers bring a distinctive perspective to legal issues and that greater responsiveness to their values may foster less adversarial, competitive, and hierarchical legal institutions. ${ }^{268}$

Relational feminism has made important contributions, but as subsequent discussion suggests, they have come at a substantial cost. Its strengths lie in its demand that the values traditionally associated with women be valued, and that legal strategies focus on transforming social institutions, rather than just assimilating women within them. By affirming characteristics conventionally associated with women, such approaches can encourage greater political cohesiveness and collective self-esteem. Relational feminism can also provide

264. See, e.g., C. DUCHEN, FEMINISM IN FRANCE (1986); T. MOI, SEXUAL/TEXTUAL POLITICS: FEMINIST LITERARY THEORY (1985); NEW FRENCH FEMINISMS: AN ANTHOLOGY (E. Marks \& I. de Courtivron eds. 1980); West, Jurisprudence and Gender, 55 U. CHI. L. REv. 1 (1988).

265. See Dubois, Dunlap, MacKinnon, Gilligan \& Menkel-Meadow, Feminist Discourse, Moral Values, and the Law: A Conversation, 34 Buffalo L. REv. 11, 74 (1985) [hereinafter Feminist Discourse] (comments of Catharine MacKinnon, emphasizing subordination); Maccoby, Gender and Relationships: A Developmental Account, 45 AM. PSYCHOLOGIST 513, 516-19(1990) (emphasizing peer group socialization).

266. Chodorow, Psychoanalytic Feminism and the Psychoanalytic in Psychology of Women, in THEORETICAL PERSPECTIVES, supra note 38, at 114. See generally N. CHODOROW, THE REPRODUCTION OF MOTHERING: PSYCHOANALYSIS AND THE SOCIOLOGY OF GENDER (1978); D. DINNERSTEIN, THE MERMAID AND THE MINOTAUR: SEXUAL ARRANGEMENTS AND THE HUMAN MALAISE (1976).

267. C. GILLIGAN, supra note 10.

268. See generally R. JACK \& D. JACK, MORAL. VISION AND PROFESSIONAL DECISIONS (1989); Bender, From Gender Difference to Feminist Solidarity: Using Carol Gilligan and the Ethic of Care in Law, 15 VT. L. REv. 1 (1990); Menkel-Meadow, Portia in a Different Voice: Speculations on a Women's Lawyering Process, 1 BERKELEY WOMEN's L.J. 39 (1985); Sherry, Civic Virtue and the Feminine Voice in Constitutional Adjudication, 72 VA. L. REV. 543, 580-616 (1986). 
theoretical underpinnings for policies that are responsive to women's particular concerns.

\section{Contextual Critiques}

Yet as was true during earlier feminist campaigns, this validation of difference raises its own set of problems at both strategic and substantive levels. As a strategic matter, affirmation of women's voice can deflect attention from the structural factors that construct and constrain it. ${ }^{269}$ Emphasizing male's association with abstract rationality and females' concern with interpersonal relationships reinforces longstanding stereotypes that have restricted opportunities for both sexes. However feminist in inspiration, any dualistic world view is likely to be appropriated for nonfeminist objectives. As the previous discussion reflects, women's caretaking priorities have served to justify their underrepresentation in demanding positions and to reinforce roles that are more separate than equal. Employer policies providing maternal but not parental leaves risk recreating the adverse consequences of protective labor legislation. Such policies encourage perceptions that nurturance is a distinctively female concern and legitimate "mommy tracks" that often become "mommy traps."270

Moreover, as a substantive matter, it is by no means clear how different women's "different" voice is. Relational feminist work has generally failed to address variations across culture, class, race, ethnicity, age, and sexual orientation. ${ }^{271}$ For example, Gilligan's data drew on small unrepresentative samples, and most empirical studies of moral development do not disclose significant gender distinctions. ${ }^{272}$ Nor does related research on managerial and political

269. See Hare-Mustin \& Maracek, Gender Meaning and the Meaning of Difference: Postmodernism and Psychology, in MAKING A DIFFERENCE, supra note 73, at 22, 52; see also Feminist Discourse, supra note 265, at 74 (comments of Catharine MacKinnon, claiming that the voice Gilligan describes is the voice of victims).

270. Couric, Women in the Large Firms: A High Price of Admission?, Nat'1 L.J., Dec. 11, 1989, at S2 (overwhelming majority of female attorneys feel taking part-time or flexible-time schedule would be serious career impediment); Kingson, supra note 175.

271. Fraser \& Nicholson, Social Criticism Without Philosophy: An Encounter Between Feminism and Postmodernism, in FEMINISM/POSTMODERNISM 19 (L. Nicholson ed. 1990); Stacey \& Thorne, The Missing Feminist Revolution in Sociology, 32 Soc. PROBS. 301 (1985). See generally sources cited infra note 272.

272. For critiques of Gilligan's methodology, see C. EPSTEIN, supra note 9, at 76-94; Benhabib, The Generalized and the Concrete Other: The Kohlberg-Gilligan Controversy and Feminist Theory, in FEMINISM AS CRITIQUE: ESSAYS ON THE POLITICS OF GENDER IN LATE-CAPITALIST SOCIETIES 77-79 (1987); Colby \& Damon, Listening to a Different Voice: A Review of Gilligan's In a Different Voice, in THE PSYCHOLOGY OF WOMEN: ONGOING DEBATES 321 (M. Walsh ed. 1987); Greeno \& Maccoby, How Different is the "Different Voice?," 11 SIGNS 310, 312-16 (1986); see also N. WALSH, THE PSYCHOLOGY OF WOMEN 27577 (1987) (bibliography). For related criticisms of psychoanalytic theories such as those found in Chodorow and Dinnerstein's work, see Fraser \& Nicholson, supra note 271. The most substantial empirical study applying Gilligan's framework in law has been a study of 36 Washington state practitioners with relatively homogeneous backgrounds. See generally R. JACK \& D. JACK, supra note 268. 
behavior reveal the kind of strong sex-linked variations that relational feminism would suggest. ${ }^{273}$

The celebration of difference risks oversimplifying and overclaiming. Recent research finds few psychological attributes on which the sexes consistently vary. ${ }^{274}$ Even for these attributes, such as aggression, spatial ability, and helping behavior, gender typically accounts for only about $5 \%$ of the variance; the similarities between men and women are far greater than the disparities, and small statistical distinctions do not support sweeping sex-based dichotomies. ${ }^{275}$ Gender differences fall along a continuum and context matters greatly in eliciting traits traditionally associated with women. ${ }^{276}$ When pressures for sex-typed behavior are strong, individuals generally will behave in expected ways, which helps transform sex-based stereotypes into self-fulfilling prophesies. ${ }^{277}$ It is misleading to discuss gender-related attributes as if they can be abstracted from the distinctive social expectations, opportunities, and hierarchies that are also linked to gender. ${ }^{278}$

Such findings suggest reasons to qualify relational claims but not to dismiss all of their potential implications. Although psychological variations between the sexes are relatively minor and socially contingent, the variation in their roles and experience continues to be substantial. As relational feminists have noted, the fact that men and women give similar answers in most surveys of moral

273. For managerial similarities, see, for example, G. POWELL, supra note 102, at 163-65; C. EPSTEN, supra note 9, at 173-84; Forisha, The Inside and the Outsider: Women in Organizations, in OUTSIER ON THE INSIDE: WOMEN AND ORGANIZATION (1981); Kanter, The Impact of Hierarchical Structures on the Work Behavior of Women and Men, in WOMEN AND WORK: PROBLEMS AND PERSPECTIVES 234, 236-45 (R. KahnHut, A. Kaplan Daniels \& R. Colvard eds. 1982). But cf. data on managerial differences cited infra notes 280 \& 285-86 and accompanying text. For political behavior, see R. ERIKSON, N. LUTTBEG \& K. TEDIN, AMERICAN PUBLIC OPINION: ITS ORIGINS, CONTENT AND IMPACT 186-87 (1980); Jacquette, Introduction to WOMEN IN POLITICS xiii-xxii (J. Jacquette ed. 1974).

274. A. EAGLY, supra note 102, at 31; Deaux \& Kite, Thinking About Gender, in ANALYZING GENDER, supra note 84, at 93,94; Hyde, supra note 16, at 64-68; Maccoby, supra note 265, at 513-15; see also E. MACCOBY \& C. JACKLIN, THE PSYCHOLOGY OF SEX DIFFERENCES (1974).

275. C. EPSTEIN, supra note 9, at 185; Deaux, supra note 104; Deaux \& Major, A Social-Psychological Model of Gender, in THEORETICAL PERSPECTIVES, supra note 38, at 89.

276. A. EAGLY, supra note 102, at 27-31, 125-32; C. EPSTEIN, supra note 9, at 185; Deaux \& Kite, supra note 274, at 93, 94; Thorne, Children and Gender: Constructions of Difference, in THEORETICAL PERSPECTIVES, supra note 38, at 100; see also R. KANTER, supra note 129, at 206-10 (suggesting that once women reach critical mass, adverse effects of tokenism and role stereotyping substantially decline); Riesman, Intimate Relationships from a Microstructural Perspective: Men Who Mother, 1 GENDER \& SOC'Y 1, 21-23 (1987) (finding that men's involuntary assumption of primary parental role was at least as powerful as sex in predicting "feminine" traits and nurturing behavior); Spangler, Gordon \& Pipkin, Token Women, An Empirical Test of Kanter's Hypothesis, 84 AM. J. Soc. 160 (1978) (discussing ratio of minority to majority as it affects achievement).

277. Unger, Imperfect Reflections of Reality: Psychology Constructs Gender, in MAKING A DIFFERENCE, supra note 73 , at $102,106$.

278. Lott, Dual Natures or Learned Behavior: The Challenge to Feminist Psychology, in MAKING A DIFFERENCE, supra note 73, at 65, 70 (if averaged differences between women and men are attributed to gender rather than to different experiences correlated with gender, description is confused with explanation). For an elaboration of women's difference in experiential rather than essential terms, see Fineman, Challenging Laws, Establishing Differences: The Future of Feminist Legal Scholarship, 42 U. FLA. L. REV. 21, 37 (1989); Williams, supra note 189; sources cited infra notes 289 \& 293. 
reasoning does not mean that they would choose similar ways of framing the question. ${ }^{279}$ Nor is it clear that most women would structure workplace policy, managerial norms, or legal practice in the same way as men if given greater decisionmaking opportunities. ${ }^{280}$ Women's distinctive biological capacities and cultural experience are inextricably linked. To make sense of gender dynamics, we need frameworks that neither overstate nor undervalue gender difference.

Recent studies involving legal practice offer a case in point. The limited data available reveal some significant sex-linked differences, but their extent depends heavily on context. For example, some studies on negotiation have found that women attach higher importance to social relations, process concerns, and cooperative interaction than do their male counterparts. ${ }^{281}$ By contrast, other surveys find that women do not respond differently than men to common negotiating dilemmas and that both sexes' negotiating styles are quite variable; individuals' tendencies toward cooperation or aggression depend on factors such as substantive objectives, power relationships, time constraints, and the sex of other parties. ${ }^{282}$ So too, surveys of judicial decisionmaking have reflected no consistent gender differences in areas such as criminal sentences and women's rights. ${ }^{283}$ In contexts presenting less pressure for conformity, however, significant differences do emerge. Opinion polls find that female judges are substantially more likely than their male colleagues to perceive gender bias as a serious problem, and all-female judicial associations display

279. Gilligan, Reply, 11 SIGNS 324, 329-31 (1986).

280. Roesner, Ways Women Lead, HARV. BuS. REv., Nov.-Dec. 1990, at 119, 120 (in certain mediumsized organizational settings, women leaders are more likely than men to report practicing interactive leadership, i.e., to share knowledge and power, to encourage participation, and to enhance subordinates' self-worth); see also infra text accompanying note 285.

281. See, e.g., D. KOLB \& G. COOLIDGE, supra note 104, at 6-18; Aries, Male/Female Interpersonal Styles in All Male, All Female and Mixed Groups, in BEYOND SEX ROLES 292 (A. Sargent ed. 1977); Kimmel \& Carnevale, Effects of Trust, Aspiration, and Gender on Negotiation Tactics, 38 J. PERSONALTY \& SOC. PSYCHOLOGY 9 (1980); Offermann \& Schrier, Social Influence Strategies: The Impact of Sex, Role, and Attitudes Toward Power, 11 PERSONALITY \& SOC. PSYCHOLOGY BULL. 286 (1985).

For reviews of research discussing differences in children's games (play of males is more rule-based and competitive while that of females is more cooperative and affiliative), see, for example, $R$. JACK \& D. JACK, supra note 268, at 130-31; Belle, Gender Differences in Children's Social Networks and Supports, in CHILDREN'S SOCIAL NETWORKS AND SOCIAL SUPPORTS 173 (D. Belle ed. 1989).

282. See, e.g., studies summarized in D. KOLB \& G. CoOLIDGE, supra note 104, at 6-18; Pruitt, Carnevale, Forcey \& Van Slyck, Gender Effects in Negotiation: Constituent Surveillance and Contentious Behavior, 22 J. EXPERIMENTAL SOC. PSYCHOLOGY 264 (1986); Pruitt \& Syna, Mismatching Opponent's Offers in Negotiation, 21 J. EXPERIMENTAL SOC. PSYCHOLOGY 103, 110-12 (1985) (finding women more likely to exploit weak opponent).

283. Cook, Will Women Judges Make a Difference in Women's Legal Rights? A Prediction from Attitudes and Simulated Behavior, in WOMEN, POWER AND POLITICAL SYSTEMS 216 (M. Rendel ed. 1981); Gruhl, Spohn \& Welch, Women as Policymakers: The Case of Trial Judges, 25 AM. J. POL. SCI. 308 (1981) (finding no gender difference except female judges' greater propensity to sentence female offenders to prison); Kritzer \& Uhlman, Sisterhood in the Courtroom: Sex of Judge and Defendant in Criminal Case Disposition, SoC. SCI. J., Apr. 1977, at 77 (finding no gender differences on criminal matters including trial and sentencing of rape defendants); Walker \& Barrow, The Diversification of the Federal Bench: Policy and Process Ramifications, 47 J. POL. 596, 607 (1985) (finding no significant male/female difference on issues of criminal law and women's rights). 
greater sensitivity to feminist concerns than do their male-dominated counterparts. $^{284}$

Other research on organizational behavior also underscores the importance of context in determining how or whether values traditionally associated with women will be expressed. Feminist political groups and all-female law firms generally have established less hierarchical, more participatory relationships than other comparable institutions. ${ }^{285}$ By contrast, most comparisons of women and men in typical organizational settings find little or no consistent gender difference in managerial style. ${ }^{286}$ Other empirical work confirms an intuitively obvious point: male and female employees who confront the same occupational pressures tend to converge in work-related responses. ${ }^{287}$ To the extent that sex-related differences emerge, they appear more related to social expectations and constraints than to essential attributes. ${ }^{288}$

These varying assessments of difference should come as no surprise in a culture that sends mixed messages about gender roles. As long as societal norms both reinforce and devalue attributes traditionally associated with women, "women's voice" will speak in multiple registers. The objective for contemporary feminists is to develop strategies that neither glorify nor discount difference, but that challenge its adverse consequences.

284. See studies summarized in Schafran, supra note 167, at 67-69; CAL. JUD. COUNCIL ADVISORY COMM. ON GENDER BIAS IN CTS., Introduction to ACHIEVING EQUAL JUSTICE FOR WOMEN AND MEN IN THE COURTS 9 (1990) (63\% of female but only $23 \%$ of male judges believe gender bias is widespread).

Martha Minow, Carolyn Heilbrun, and Judith Resnik describe a representative example. At a recent conference of women judges, there was opportunity to do volunteer work at a local soup kitchen and scheduled discussion on issues such as judicial treatment of rape victims who break down during their testimony. Heilbrun \& Resnik, Convergences: Law, Literature, and Feminism, 99 YALE L.J. 1913, 1948 (1989); M. Minow, Illegal Feminism (1990) (unpublished manuscript). For discussion of the National Association of Women Judges, see Klein, Woman Justice-Does She View the Law Differently?, 26 CT. REV. 18, 21-23 (1989). In an earlier draft of this Essay, Cynthia Epstein suggested that this example attempted to prove too much and carried connotations of "lady bountiful." She quite rightly noted that both sexes work in programs for low-income communities and that female professionals are rarely regular volunteers. However, the point of the example is not to make universal claims about women's special empathy, but rather to suggest that certain social contexts are more apt to evoke it, and that a variety of cultural forces make all-female associations likely to express different concerns than male-dominated organizations.

285. C. EPSTEN, supra note 53, at 130-61; Martin, Rethinking Feminist Organizations, 4 GENDER \& Soc'Y 182 (1990) (discussing research finding that women's political organizations are more participatory and less hierarchical than other comparable organizations).

286. Most studies find no differences and conclude that organizational selection and socialization processes work against stereotypical behavior. See sources cited supra notes 273 \& 276 . A recent meta-analysis of prior work suggests that female leadership tends to be slightly more interpersonally oriented and less autocratic however, and speculates that these traits may be in part attributable to the less supportive atmosphere that female managers often face. Skepticism about women's ability may induce them to engage in more participatory collaborative processes. Eagly \& Johnson, Gender and Leadership Style: A MetaAnalysis, 108 PSYCHOLOGICAL BULL. 233, 235, 242-48 (1990); see also note 280.

287. P. ENGLAND \& G. FARRAS, supra note 202, at 137-41 (research suggesting individuals develop psychological styles required to survive in structural position they hold); Gomez-Mejia, Sex Differences During Occupational Socialization, 26 ACAD. MGMT. J. 492, 495 (1983); see also K. FERGUSON, THE FEMINIST CASE AGAINST BUREAUCRACY 94 (1984); G. POWELL, supra note 102, at 179-81; C. EPSTELN, supra note 9, at 179-81.

288. See supra notes $275-78$ \& 286 and accompanying text. 
Reformulating the problem in these terms builds on a second strain of contemporary feminist theory, one concerned not simply with women's differences from men but also with women's differences from each other. Postmodern theoretical accounts have drawn increasing attention to the multiple forces that constitute women's identity across race, ethnicity, class, age, religion, sexual orientation, and so forth. ${ }^{289}$ Yet this focus has also underscored a longstanding paradox in feminist theory and practice. What gives feminism its unique perspective is its claim to speak from women's experience. But that same experience counsels attention to the differences in women's backgrounds, perceptions, and priorities. There is no "generic woman," nor any monolithic "woman's point of view."290 Feminism has increasingly become "feminisms," which complicates the search for theoretical coherence and political cohesion. ${ }^{291}$

Yet the factors that divide feminists could also be a basis for enriching analysis and broadening coalitions. As Audre Lorde has noted, it is not "our differences which separate [us as] women, but our reluctance to recognize those differences and to deal effectively with the distortions which have resulted."292 The same values that underpin feminism's struggle against gender inequality demand its opposition to other forms of subordination. We cannot empower all women without challenging the multiple sources of disempowerment that many women face. The problem is how to make such challenges a basis for psychological affinity and political activism.

To realize its full potential, the feminist movement must both expand its practical agenda and qualify its theoretical claims. No single categorical frame-. work can adequately address the dynamics of difference. We remain caught between the need to affirm our gender identity and to challenge its constraints, to claim solidarity and to acknowledge diversity. The sameness/difference dilemma cannot be resolved; it can only be reformulated. Our focus needs to

289. Di Stefano, Dilemmas of Difference: Feminism, Modernity, and Postmodernism, in FEMINISM/POSTMODERNISM, supra note 271, at 63,73; Flax, Postmodernism and Gender Relations in Feminist Theory, 12 SIGNS 621, 634-39 (1987); Gagnier, Feminist Postmodernism: The End of Feminism or the Ends of Theory?, in THEORETICAL PERSPECTIVES, supra note 38, at 23-26; and sources cited infra notes 290-92.

290. E. SPELMAN, INESSENTIAL WOMAN: PROBLEMS OF EXCLUSION IN FEMINIST THOUGHT 114, 167 (1988); Rhode, The Woman's Point of View, 38 J. LEGAL EDUC. 39, 41, 44 (1988). On the failure of much feminist jurisprudence to take adequate account of diversity, see Austin, Sapphire Bound!, 1989 WIs. L. REV. 539, 539-46; Harris, Race and Essentialism in Feminist Legal Theory, 42 STAN. L. REV. 581, 585-608 (1990); Kline, Race, Racism, and Feminist Legal Theory, 12 HARV. WOMEN's L.J. 115, 121 (1989).

291. A. RICH, Disloyal to Civilization: Feminism, Racism, Gynephobia, in ON LIES, SECRETS, AND SILENCE: SEleCTED PROSE, 1966-1978, at 275, 299 (1979); Alcoff, Cultural Feminism Versus PostStructuralism: The Identity Crisis in Feminist Theory, 13 SIGNS 405, 406 (1988); Bordo, Feminism, Postmodernism, and Gender-Scepticism, in FEMINISM/POSTMODERNISM, supra note 271, at 133, 134-42; Harding, The Instability of the Analytic Categories of Feminist Theory, 11 SIGNS 645 (1986); Keller, Holding the Center of Feminist Theory, 12 WOMEN's STUD. INT'L F. 313, 314 (1989).

292. A. LORDE, Age, Race, Class, and Sex: Women Redefining Difference, in SISTER OUTSIDER 114, 122 (1984). On the need for "multiple consciousness," see Matsuda, When the First Quail Calls: Multiple Consciousness as Jurisprudential Method, 11 WOMEN's RTS. L. REP. 7, 9 (1989). 
shift from differences to disadvantage and to the social conditions that perpetuate it. ${ }^{293}$

To make significant progress, our strategies must rest on feminist principles, not feminine stereotypes. The issues of greatest concern to women are not simply "women's issues." Although the feminist platform incorporates values traditionally associated with women, the stakes in its realization are ones that both sexes share.

\section{B. Individual Premises and Social Priorities}

A related and equally longstanding challenge is how to make this feminist agenda a matter of personal as well as collective responsibility. As historical and social science research make clear, a sense of injustice is necessary but not sufficient to provoke resistance. The distribution of resources for collective mobilization is equally critical. ${ }^{294}$ Women's access to such resources has been constrained by their disproportionate assumption of domestic burdens and their disproportionate concentration among the poor. Moreover, women constitute a dispersed and heterogeneous group, which heightens the barriers to effective organization. ${ }^{295}$ The guarantees of equality in formal treatment that have been able to secure consensus have been unable to ensure equality in social experience. Women's most fundamental problem is how to politicize the problem-how to increase a sense of shared identity, purpose, and power through collective action.

\section{Cultural Assumptions}

This problem is compounded by the individualist ethic that dominates American public discourse. Issues of group equality are often translated into matters of individual opportunity, and shared needs are left to private solutions. Barbara Bush's admonition to the 1990 Wellesley graduating class typifies current wisdom: "Your success as a family, our success as a society, depends

293. C. MACKINNON, TOWARD A FEMINIST THEORY OF THE STATE 117-25, 180-88, 306-13; D. RHODE, supra note 3. For an account of "relational" frameworks that focus on the construction and consequences of difference, see M. MNNOW, supra note 190, at 41-42, 56-60, 217-19, 375-77. For accounts of the role of practical reasoning in this effort, see generally Bartlett, Feminist Legal Methods, 103 HARV. L. REV. 829 (1990); Radin, The Pragmatist and the Feminist, 63 S. CAL. L. REV. 1669 (1990).

294. See F. CROSBY, supra note 208, at 22; C. TILLY, From MOBILIZATION TO REVOLUTION 54-57, 83-84 (1978). In one representative study, the magnitude of female employees' feelings of deprivation had no significant effect on their willingness to engage in collective responses; the determining factors were the availability of resources and personal risks associated with organized action. Martin, supra note 219, at 217, 232; see also Martin, Brickman \& Murray, Moral Outrage and Pragmatism: Explanations for Collective Action, 20 J. EXPERIMENTAL \& SOC. PSYCHOLOGY 484, 486 (1984).

295. For barriers to organizing diffuse groups, see W. GAMSON, THE STRATEGY OF SOCLAL PROTEST (1975); C. TILLY, supra note 294, at 83-84; Hochschild, supra note 213, at 195. For successful grassroots efforts, see A. BOOKMAN \& S. MORGEN, WOMEN AND THE POLITICS OF EMPOWERMENT (1988). 
not on what happens in the White House but on what happens inside your house." $" 296$

The popular media offer variations on a similar theme. The feminist message, as repackaged for mass consumption, often carries a distinctly unfeminist undertone. Women's liberation reportedly lies in self-improvement, not social activism. Celebrated best-sellers offer cautionary tales of both success and failure, but their underlying message is much the same. Whether the topic is supermoms and how they manage, or Women Who Can't Say No and the Men Who Control Them, the moral is that solutions for women's problems lie with individual women. ${ }^{297}$ It is just a matter of choosing the right man, the right wardrobe, the right career sequence, or the right time-management techniques. "Political correctness" has become more a matter of self-presentation than social activism. Feminism's emphasis on self-transformation as a prelude to political change is being replaced with a focus on self-transformation as a substitute for political change. ${ }^{298}$

The implications of this ideology were evident in Ruth Sidel's recent study of aspirations among young women. Cutting across boundaries of race, class, and ethnicity was a shared myth: that women can "have it all" without the support of an extended family, a community, or the state. ${ }^{299}$ The "all" is not a modest vision. Nor for most of these women is it a remotely realistic one. What they expect is a successful career, happy marriage, well-adjusted children, and plenty of money; what they lack is any appreciation of the broader societal changes that such a vision would require. ${ }^{300}$

For too many women, feminism is everywhere and nowhere. Its insistence on individual opportunity is widely shared while its call to common action is widely ignored. The women's movement has increased aspirations to gender equality but not the collective commitment necessary to realize them. A perspective so self-absorbed is ultimately self-defeating. We cannot expect that individual solutions will prove adequate to meet societal problems. Ironically enough, it was Raisa Gorbachev's Wellesley comments that identified

296. Text of Mrs. Bush's Speech, Wash. Post, June 2, 1990, at C4, col. 1.

297. Representative examples include: C. COWAN \& M. KINDER, SMART WOMEN, FOOLISH CHOICES: FINDING THE RIGHT MEN AND AVOIDING THE WRONG ONES (1985); K. LEMAN, THE PLEASERS: WOMEN WHO CAN'T SAY NO AND THE MEN WHO CONTROL THEM (1987); R. NORWOOD, WOMEN WHO LOVE TOO MUCH: WHEN YOU KEEP WISHING AND HOPING HE'Ll CHANGE (1985). For critiques of this genre, see R. SIDEL, ON HER OWN: GROWING UP IN THE SHADOW OF THE AMERICAN DREAM 156-57, 251 (1990); Lerner, Problems for Profit?, WOMEN's REV. BOOKS, Apr. 1990, at 15, 16.

298. Kauffman, The Anti-Politics of Identity, SOCIALIST P.EV., Jan.-Mar. 1990, at 67, 77-78; see also Ehrenreich, The Women's Movements: Feminist and Antifeminist, RADICAL AM., Spring 1981, at 93, 97 (discussing media's transformation of feminism from social movement into self-improvement program for upwardly mobile women); Epstein, Rethinking Social Movement Theory, SOCIALIST REV., Jan.-Mar. 1990, at 35 .

299. See R. SIDEL, supra note 297 , at 9 , 29. Although Sidel found certain class-based differences, virtually all the women in her study shared individualist premises. $I d$. at 226 .

300. Id. at 15-35; see also J. CHAFETZ, supra note 9, at 212; Boneparth, Introduction: A Framework for Policy Analysis, in WOMEN, POWER, AND POLICY, supra note 39, at 1; Ehrenreich, supra note 298, at 98. 
America's current impasse: "At this juncture, each of us looks for her own solution to the problem. This is one of the problems society ha[s] to deal with." ${ }^{301}$

\section{Collective Aspirations}

That point is gaining wider recognition, in part because of opportunities like the symposium that prompted these comments. The importance of such occasions should not be taken for granted. Throughout most of this nation's history, the advice to professional women has generally been to avoid "women's issues." For female attorneys, the prevailing wisdom has been never to "take sex into practice." 302 Over the last two decades, however, these attitudes have begun to change. The growth in women's professional and political organizations, in grass-roots campaigns and gender bias commissions, and in feminist scholarship and symposia, all testify to the distance we have traveled. The challenge remaining is to act on the possibilities they offer.

To that end, our focus must shift from formal opportunity to the social forces that construct and constrain it. Our analysis of sex-based difference must become less categorical and more contextual. Our objectives must center on transforming current power structures as well as enlarging women's place within them. Finally, and most importantly, our aspirations must include a broader understanding of "the problem" and of the strategies most likely to politicize it. A half-century ago, speaking before an audience of women professionals, Virginia Woolf observed that their access to such occupations for the first time in history was an event of "extraordinary interest and importance." Yet although their paths were "nominally open," hidden obstacles remained:

You have won rooms of your own in the house hitherto exclusively owned by men. You are able, though not without great labour and effort, to pay the rent .... But this freedom is only a beginning; the room is your own, but it is still bare .... How are you going to furnish it, how are you going to decorate it? With whom are you going to share it, and upon what terms? These, I think are questions of the utmost importance and interest. For the first time in history you are able to ask them ... [and] to decide for yourselves what the answers should be. ${ }^{303}$

These remain the questions that define our problem and our challenge.

301. As quoted in Butterfield, Family First, Mrs. Bush Tells Friend and Foe at Wellesley, N.Y. Times, June 2,1990 , at 1 , col. 4,5 , col. 1 .

302. N. CoTT, supra note 55, at 232 (emphasis omitted).

303. V. WOOLF, Professions for Women, in THE DEATH OF THE MOTH 235, 242 (1942), reprinted in V. WOOLF, WOMEN AND WRITING 57, 63 (M. Barrett ed. 1979). 
